UNIVERSIDADE DE BRASÍLIA

FACULDADE DE CIÊNCIAS DA SAÚDE

AMABEL FERNANDES CORREIA

AVALIAÇÃO DA ATIVIDADE ANTIFÚNGICA DE EXTRATOS DE PLANTAS DO CERRADO BRASILEIRO SOBRE ISOLADOS CLÍNICOS DE CANDIDA SPP.

BRASÍLIA 


\section{AVALIAÇÃO DA ATIVIDADE ANTIFÚNGICA DE EXTRATOS DE PLANTAS DO CERRADO BRASILEIRO SOBRE ISOLADOS CLÍNICOS DE CANDIDA SPP.}

Tese apresentada ao Programa de Pós-graduação em Ciências Farmacêuticas da Faculdade de Ciências da Saúde, Universidade de Brasília, como requisito parcial à obtenção do título de Doutora em Ciências Farmacêuticas.

Orientadora: Prof ${ }^{\mathrm{a}}$. Dra ${ }^{\mathrm{a}}$. Yanna Karla de Medeiros Nóbrega Coorientadora: Prof ${ }^{a}$. Dra ${ }^{\mathrm{a}}$. Dâmaris Silveira

BRASÍLIA 
Ficha catalográfica elaborada automaticamente, com os dados fornecidos pelo(a) autor(a)

Fernandes Correia, Amabel

FC824a AVALIAÇÃO DA ATIVIDADE ANTIFÚNGICA DE EXTRATOS DE PLANTAS DO CERRADO BRASILEIRO SOBRE ISOLADOS

CLÍNICOS DE CANDIDA SPP. / Amabel Fernandes Correia; orientador Yanna Karla de Medeiros Nóbrega; coorientador Dâmaris Silveira. -- Brasília, 2016. $95 \mathrm{p}$.

Tese(Doutorado - Doutorado em Ciências Farmacêuticas) -- Universidade de Brasília, 2016.

1. Candida spp. 2. Candidíase sistêmica. 3. antifúngicos. 4. Plantas Medicinais. 5. Atividade antifúngica. I. de Medeiros Nóbrega, Yanna Karla, orient. II. Silveira, Dâmaris, coorient. III. Título. 


\section{AVALIAÇÃO DA ATIVIDADE ANTIFÚNGICA DE EXTRATOS DE PLANTAS DO CERRADO BRASILEIRO SOBRE ISOLADOS CLÍNICOS DE CANDIDA SPP.}

Tese apresentada ao Programa de Pós-graduação em Ciências Farmacêuticas da Faculdade de Ciências da Saúde, Universidade de Brasília, como requisito parcial à obtenção do título de Doutora em Ciências Farmacêuticas.

Aprovada em 19 de Fevereiro de 2016

\section{BANCA EXAMINADORA}

Profa. Dra . Yanna Karla de Medeiros Nóbrega (UnB)

Profa. Dra ${ }^{a}$ Rosângela Vieria de Andrade (UCB)

Profa. Dra. Mariana Machado Hecht (UnB)

Profa. Dra . Yris Maria Fonseca Bazzo (UnB)

Prof. Dr. Luís Cláudio Gonçalves de Castro (UnB) 
Este trabalho é dedicado aos meus Pais, meus Irmãos e aos meus Sobrinhos. 


\section{AGRADECIMENTOS}

A DEUS, por me fazer acreditar, que para realizar o impossível, basta ter fé. Obrigada Senhor por tudo.

A PAPAI e a MAMÃE, pelo exemplo de seres humanos dignos, nos quais me espelho e tenho orgulho de tê Los como pais.

Aos meus irmãos, Fernando, Dianinha e Deinha pelo companherismo, incentivo e muito carinho.

A Sophia e a Juninho, pelo o amor puro e verdadeiro, pois mesmo sem entender o que "titia" estava estudando, compreenderam e torceram por mim.

A minha orientadora, Yanna (Ya), por ser minha amiga e minha "irmã galega", por preencher o meu lado razão, que não consigo administrá-lo sem que ela esteja por perto, por não desistir de mim e por está sempre presente na minha vida.

A minha Coorientadora, Dâmaris, pela amizade, confiança e por me mostrar que as dificuldades representam o maior incentivo para conquistar o que você quer.

Ao Filipe e Francisco, por me acolher com todo o carinho e me proporcionar momentos inesquecíveis em Sintra, que vou guardar por toda vida.

A Ana Vencá - "Carolina", amiga portuguesa, meu anjo da guarda em Lisboa, que além de contribuir no aperfeiçoamento deste trabalho, me ajudou a enfrentar a saudade e dias frios de Inverno em Portugal. Obrigada também ao João (seu esposo) e sua familia que me receberam com todo o carinho em sua casa.

A Professora Maria da Luz, pela a recepção e colaboração técnico científica.

A todos do Laboratório Central de Saúde Pública do Distrito Federal (LACEN-DF), pelo o apoio, motivação e incentivo.

A todos do Laboratório Interdisciplinar de Biociências e do Laboratório de Doenças Crônicasdegenerativas e Imunogenéticas, que me receberam com carinho e por acreditaram na minha capacidade.

Ao Laboratório de Produtos Naturais, pela parceria e cooperação técnico e científica.

Ao Instituto de Higiene e Medicina Tropical (IHMT) da Universidade Nova de Lisboa (UNL), pela cooperação científica e pela contribuição na realização deste trabalho.

E a CAPES, pela o suporte técnico e financeiro, o qual proporcionou a realização de parte do meu projeto em Lisboa, Portugal. 


\section{RESUMO}

CORREIA, Amabel Fernandes. AVALIAÇÃO DA ATIVIDADE ANTIFÚNGICA DE EXTRATOS DE PLANTAS DO CERRADO BRASILEIRO SOBRE ISOLADOS CLÍNICOS DE CANDIDA SPP. Brasília, 2016. Tese (Doutorado em Ciências Farmacêuticas) - Faculdade de Ciências da Saúde, Universidade de Brasília, Brasília, 2016.

A maioria dos casos de candidíase sistêmica era atribuído à espécie de Candida albicans. Entretanto, Candida não albicans têm sido identificadas como patógenos em infecções humanas, representando mudança de prevalência com percentual por vezes superior a Candida albicans. Esta mudança na etiologia de candidíase sistêmica, está relacionada a novos métodos diagnósticos, como a identificação das espécies, empregando técnicas moleculares, e pode refletir a alta taxa de resistência a antifúngicos de Candida não albicans. Este estudo teve o objetivo de caracterizar isolados clínicos de Candida spp. quanto aos aspectos epidemiológicos e terapêuticos e, como proposta à resistência aos antifúngicos apresentados por Candida spp., foram avaliados a atividade antifúngica de extratos de plantas do cerrado brasileiro. Foram utilizados métodos clássicos e moleculares de identificação microbiológica e teste de disco difusão segundo protocolo de referência. Os métodos de identificações microbiológicas caracterizaram 150 isolados clínicos de pacientes com suspeita de infecções sistêmicas no Distrito Federal, Brasil, entre Janeiro/2011 e Dezembro/2012. Candida albicans foi a espécie mais isolada (50,6\%), seguida por Candida parapsilosis (21,3\%), Candida tropicalis (16,6\%), Candida glabrata (8,0\%), Candida krusei (0,7\%), Candida guilliermondii (0,7\%), Candida intermedia (0,7\%) e Kadamaea ohmeri (0,7\%), que foram isoladas em amostras de lavado broncoalveolar, sangue e escarro, predominantemente em pacientes do sexo masculino com idade entre 21 e 60 anos. $O$ teste de disco difusão foi utilizado para determinar a atividade antifúngica de agentes convencionais e extratos de plantas. Na atividade antifúngica de agentes convencionais, a maioria dos isolados clínicos de Candida foram sensíveis a anfotericina B (97,9\%); 91,9\% foram sensíveis a voriconazol; 91,3\% a fluconazol; 73\% a itraconazol e 2,7\% a 5-fluorocitosina. A resistência cruzada aos azólicos foi demonstrada por isolados de C. glabrata e C. intermedia. Na avaliação da atividade antifúngica dos extratos, as seis espécies de plantas, Eugenia dysenterica, Pouteria ramiflora, Pouteria torta, Erythroxylum subrotundum, Erythroxylum daphnites e Bauhinia rufa apresentaram efeito inibitório sobre diferentes espécies de Candida, sendo Candida glabrata a espécie mais inibida. Nossos resultados apontam, que os extratos avaliados possuem fitocompostos com potenciais atividades antifúngicas contra espécies de Candida, principalmente espécies de Candida não albicans, que representam atualmente grande revelância clínica e terapêutica.

Palavras chaves: Candida spp., candidíase, antifúngicos, plantas medicinais, atividade antifúngica 


\begin{abstract}
CORREIA, Amabel Fernandes. EVALUATION ANTIFUNGAL ACTIVITY OF CRUDE EXTRACTS FROM BRAZILIAN CERRADO PLANTS AGAINST CLINICAL ISOLATES CANDIDA SPECIES. Brasília, 2016. Tese (Doutorado em Ciências Farmacêuticas) Faculdade de Ciências da Saúde, Universidade de Brasília, Brasília, 2016.
\end{abstract}

Most cases of systemic candidiasis were assigned to the Candida albicans species. However, non albicans Candida have been identified as human pathogens in infections representing a change in prevalence with a percentage at times related to Candida albicans. This change in the etiology of systemic candidiasis is related to new diagnostic methods, such as identification of species using molecular techniques and may reflect on the high rate of resistance to antifungal Candida non albicans. This study's main proposed objective is to characterize clinical isolated cases of Candida spp. to epidemiological and therapeutic aspects resisting to antifungal agents during treatment. Plant extracts of Brazilian Cerrado were used to evaluate. Microbiological identification on classic and molecular methods, and disk diffusion test were used as a protocol reference. The microbiological identification methods characterized 150 isolated clinical in patients suspected of systemic infection in the Federal District, Brazil, between January/2011 and December/2012. Candida albicans is the most commonly isolated species (50.6\%), followed by Candida parapsilosis (21.3\%), Candida tropicalis (16.6\%), Candida glabrata (8.0\%), Candida krusei (0.7\%), Candida guilliermondii $(0.7 \%)$, Candida intermedia $(0.7 \%)$ and Kadamaea ohmeri $(0.7 \%)$, which were isolated in bronchoalveolar lavage samples, blood and mucus, predominantly in male patients aged between 21 and 60 years. The disk diffusion test was used to determine the antifungal activity of conventional agents and plant extracts. In conventional antifungal agents, most isolated clinical cases of Candida were sensitive to amphotericin B ( $97.9 \%$ ); $91.9 \%$ were susceptible to voriconazole; $91.3 \%$ to fluconazole; $73 \%$ itraconazole and $2.7 \%$-fluorocytosine. The cross resistance to azoles has been demonstrated by isolated cases of $C$. glabrata and $C$. intermedia. When evaluating the antifungal activity of the extracts, the six species of plants, Eugenia dysenterica, Pouteria ramiflora, Pouteria torta, Erythroxylum subrotundum, Erythroxylum daphnites and Bauhinia rufa showed inhibitory effect on various Candida species, and Candida glabrata the most inhibited species. Our results suggest that the extracts evaluated have compounds with potential antifungal activity against Candida species, especially Candida non albicans species, representing currently important great clinical and therapeutic.

Keywords chaves: Candida spp., candidiasis, antifungal, medicinal plantas, antifungal activity 


\section{LISTA DE FIGURAS}

Figura 1 - Principais morfologias de patógenos fúngicos humanos........................................17

Figura 2 - Características macroscópicas e microscópicas dos isolados clínicos.....................52

Figura 3 - Resultados da prova do tubo germinativo (PTG)..................................................53

Figura 4 - Resultados da identificação presuntiva em meio cromogênico................................54

Figura 5 - Resultados da identificação bioquímica por reações enzimáticas e colorimétricas.54

Figura 6 - Resultados divergentes nas metodologias empregadas na caracterização fenotípica de isolados clínicos.

Figura 7 - Gel de agarose mostrando os resultados obtidos por PCR multiplex......................57

Figura 8 - Resultados da identificação dos isolados clínicos por PCR multiplex.....................58

Figura 9 - Gel de agarose mostrando a amplificação da região ITS por PCR RFLP................59

Figura 10 - Gel de agarose mostrando os resultados obtidos por PCR RFLP.........................59

Figura 11 - Resultado final da identificação dos isolados clínicos

Figura 12 - Perfil de sensibilidade de Candida albicans aos agentes antifúngicos convencionais

Figura 13 - Perfil de sensibilidade de Candida parapsilosis aos agentes antifúngicos convencionais

Figura 14 - Perfil de sensibilidade de Candida tropicalis aos agentes antifúngicos convencionais

Figura 15 - Perfil de sensibilidade de Candida glabrata aos agentes antifúngicos convencionais

Figura 16 - Perfil de sensibilidade de todos os isolados clínicos aos agentes antifúngicos convencionais

Figura 17 - Isolados clínicos com múltiplas resistências.

Figura 18 - Extratos brutos vegetais com atividade antifúngica. 
Figura 19 - Atividade antifúngica do extrato aquoso de Eugenia dysenterica .75

Figura 20 - Atividade antifúngica do extrato aquoso de Pouteria ramiflora...........................76

Figura 21 - Atividade antifúngica do extrato etanólico de Pouteria ramiflora .........................76

Figura 22 - Atividade antifúngica do extrato etanólico de Pouteria torta...............................77

Figura 23 - Atividade antifúngica do extrato aquoso de Erythroxylum subrotundum.............78

Figura 24 - Atividade antifúngica do extrato aquoso de Bauhinia rufa..................................78

Figura 25 - Atividade antifúngica do extrato etanólico de Erythroxylum subrotundum...........79

Figura 26 - Atividade antifúngica do extrato etanólico de Bauhinia rufa...............................79

Figura 27 - Atividade antifúngica do extrato aquoso de Erythroxylum daphnites....................80 


\section{LISTA DE TABELAS}

Tabela 1 - Materiais biológicos coletados e características da população em estudo. 38

Tabela 2 - Controles e substratos utilizados na identificação bioquímica de leveduras.

Tabela 3 - Primers universais e espécies específicos utilizados na PCR multiplex e dimensões dos fragmentos amplificados para Candida spp.

Tabela 4 - Dimensões dos fragmentos amplificados para Candida spp. após PCR RFLP e restrição com MspI.

Tabela 5 - Padrões interpretativos dos diâmetros dos halos de inibição e CIM dos agentes antifúngicos.

Tabela 6 - Espécies de plantas utilizadas, família botânica e voucher.

Tabela 7 - Plantas utilizadas, partes da planta, solventes e extratos brutos vegetais

Tabela 8 - Comparação das metodologias de identificação fenotípica utilizadas no estudo....55

Tabela 9 - Comparação entre os métodos moleculares PCR multiplex e PCR RFLP...

Tabela 10 - Discrepância entre métodos clássicos, moleculares e espectrometria de massas MALDI TOF.

Tabela 11 - Distribuição das espécies de leveduras por materiais biológicos.

Tabela 12 - Distribuição das espécies de leveduras por faixa etária

Tabela 13 - Distribuição das espécies de leveduras por gênero 66

Tabela 14 - Diâmetros dos halos de inibição para as cepas padrões ATCC

Tabela 15 - Perfil de sensibilidade de C. krusei, C. guilliermondii, C. intermedia e $K$. ohmeri.....

Tabela 16 - Atividade antifúngica dos extratos brutos sobre cepas ATCC pelo método de Disco Difusão. 73

Tabela 17 - Concentrações inibitórias mínimas dos extratos brutos vegetais de plantas do cerrado brasileiro, contra cepas padrões ATCC de Candida spp. .74

Tabela 18 - Atividade antifúngica dos extratos brutos vegetais .80 


\section{LISTA DE ABREVIATURAS}

\begin{tabular}{|c|c|}
\hline $5 \mathrm{FC}$ & 5-fluorocitosina \\
\hline $5 F U$ & 5-fluorouracil \\
\hline A & Extrato Aquoso \\
\hline AARG & L-Arginil-L-Arginina- $\beta$-Naftilamida \\
\hline $\mathrm{ABC}$ & ATP - Binding Cassette Superfamily \\
\hline AGAL & p-Nitrofenil- $\alpha$-D-Galactopiranósido \\
\hline AGL1 & p-Nitrofenil- $\alpha$-D-Glicopiranósido 1 \\
\hline AGL2 & p-Nitrofenil- $\alpha$-D-Glicopiranósido 2 \\
\hline ALA & L-Alanina-4-Metoxi- $\beta$-Naftilamida \\
\hline ATCC & American Type Culture Colletion \\
\hline BDF & p-Nitrofenil-ß-D-Fucopiranósido \\
\hline BGAL & 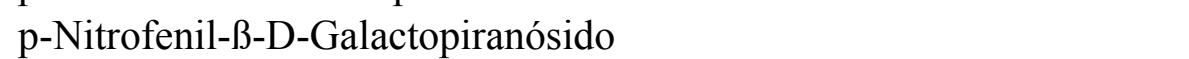 \\
\hline BGL & p-Nitrofenil-ß-D-Glicopiranósido \\
\hline BHIA & Ágar Infusão de Cérebro e Coração \\
\hline BNAC & B-Naftilamida \\
\hline Calb & Candida albicans \\
\hline Cdub & Candida dubliniensis \\
\hline CEP/SES-DF & Comitê de Ética em Pesquisa da Secretaria de Estado de Saúde do DF \\
\hline Cint & Candida intermedia \\
\hline Cgla & Candida glabrata \\
\hline Cgui & Candida guilliermondii \\
\hline CIM & Concentração Inibitória Mínima \\
\hline Ckru & Candida krusei \\
\hline Clus & Candida lusitaniae \\
\hline CLSI & Clinical and Laboratory Standards Institute \\
\hline Cpar & Candida parapsilosis \\
\hline $\mathrm{CPF}$ & Controle Positivo Fluconazol \\
\hline Ctro & Candida tropicalis \\
\hline DNA & Ácido Dexoribonucleico \\
\hline $\mathrm{E}$ & Extrato Etanólico \\
\hline EDY1 & Eugenia dysenterica \\
\hline FDA & Food and Drug Administration \\
\hline FIOCRUZ-RJ & Fundação Osvaldo Cruz do Rio de Janeiro \\
\hline GGLY & Glicilglicina- $\beta$-Naftilamida \\
\hline GLAR & Glicil-L-Arginina-4-Metoxi-ß-Naftilamida \\
\hline GLPR & 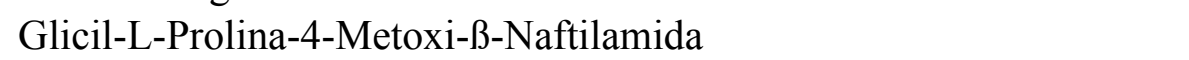 \\
\hline GLY & Glicina-ß-Naftilamida \\
\hline HAB & Hospital de Apoio de Brasília \\
\hline HBDF & Hospital de Base do Distrito Federal \\
\hline HFA & Hospital das Forças Armadas \\
\hline HIS & L-Histidina- $\beta$-Naftilamida \\
\hline HRAN & Hospital Regional da Asa Norte \\
\hline HRAS & Hospital Regional da Asa Sul \\
\hline
\end{tabular}




\begin{tabular}{|c|c|}
\hline $\mathrm{HRBz}$ & Hospital Regional de Brazlândia \\
\hline $\mathrm{HRC}$ & Hospital Regional de Ceilândia \\
\hline $\mathrm{HRG}$ & Hospital Regional do Gama \\
\hline $\mathrm{HRGu}$ & Hospital Regional do Guará \\
\hline $\mathrm{HRPa}$ & Hospital Regional do Paranoá \\
\hline HRPl & Hospital Regional de Planaltina \\
\hline HRSam & Hospital Regional de Samambaia \\
\hline HRS & Hospital Regional de Sobradinho \\
\hline HRT & Hospital Regional de Taguatinga \\
\hline HUB & Hospital Universitário de Brasília \\
\hline IDX & 3-Indoxilfosfato \\
\hline ITS1 & Internal Transcribed Spacer 1 \\
\hline ITS2 & Internal Transcribed Spacer 2 \\
\hline Kohm & Kodamaea ohmeri \\
\hline LACEN-DF & Laboratório Central de Saúde Pública do Distrito Federal \\
\hline LYAL & L-Lisil-L-Alanina-4-Metoxi-ß-Naftilamida \\
\hline MALDI-TOF & Matrix Assisted Laser Desorption Ionization Time-of-flight \\
\hline MFS & Major Facilitator superfamily \\
\hline NAG & p-Nitrofenil-N-Acetil- $\beta-D-G l i c o s a m i n a$ \\
\hline NPC & Nitrofenil \\
\hline NPM & Núcleo de Parasitologia e Micologia \\
\hline PAN-FISH & Peptide Nucleic Acid Fluorescent in situ Hybridization \\
\hline $\mathrm{pb}$ & Pares de base \\
\hline PCR & Reação em Cadeia da Polimerase \\
\hline PCR multiplex & Reação em Cadeia da Polimerase multiplex \\
\hline PRO & L-Prolina-ß-Naftilam \\
\hline PTG & Prova do Tubo Germinativo \\
\hline $\mathrm{R}$ & Resistente \\
\hline RFLP & Restriction Fragment Length Polymorphism \\
\hline RNA & Ácido Ribonucleico \\
\hline rRNA & Ácido Ribonucleico Ribossômico \\
\hline RT PCR & Real Time PCR \\
\hline $\mathrm{S}$ & Sensível \\
\hline SAPs & Proteinases Aspartil Secretoras \\
\hline SDD & Sensível Dose Dependente \\
\hline STY & L-Senil-L-Tirosina- $\beta$-Naftilamida \\
\hline SUC1 & Sucrose 1 \\
\hline SUC2 & Sucrose 2 \\
\hline TRE & Trealose \\
\hline TYR & L-Tirosina- $\beta$-Naftilamida \\
\hline UNI1 & Primer Universal 1 \\
\hline UNI2 & Primer Universal 2 \\
\hline URE & Ureia \\
\hline
\end{tabular}




\section{SUMÁRIO}

1 INTRODUÇÃO ..........................................................................................................16

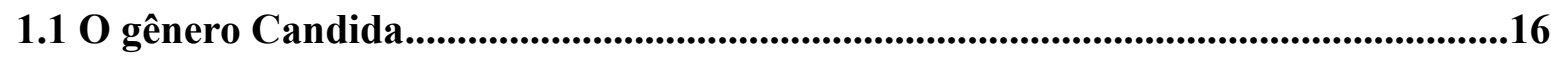

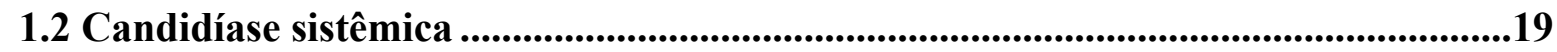

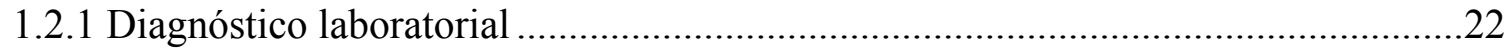

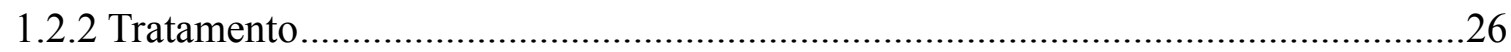

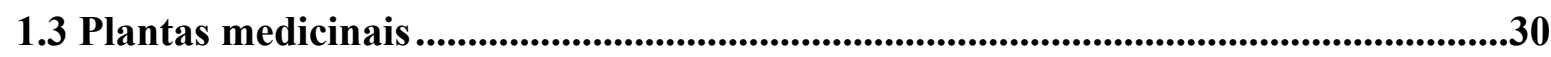

1.3.1 Plantas do cerrado selecionadas para o screening da atividade antifúngica..............32

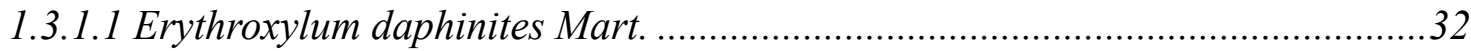

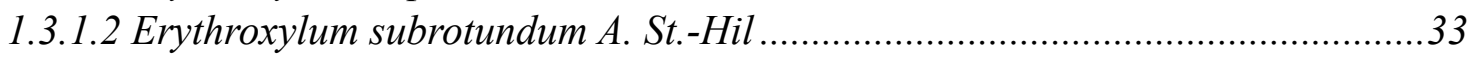

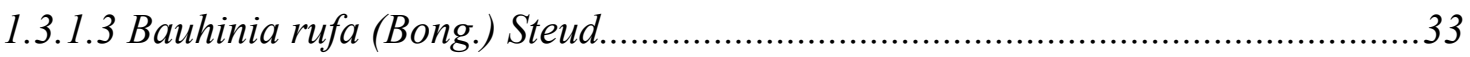

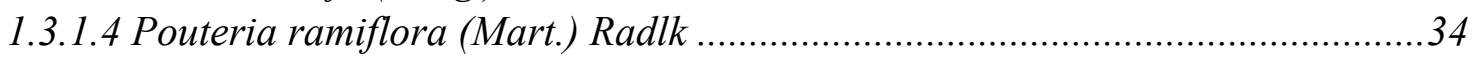

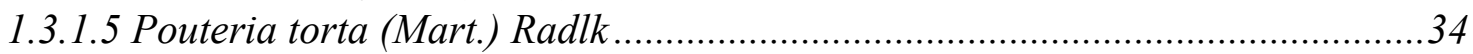

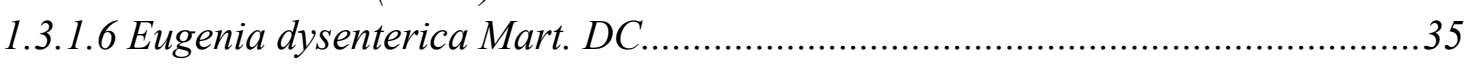

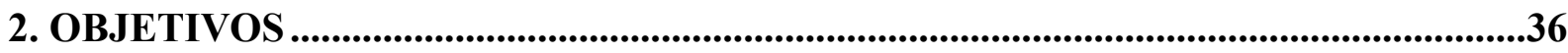

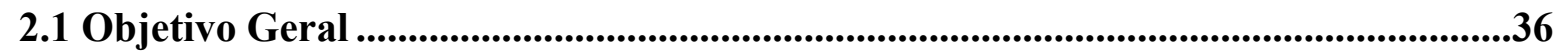

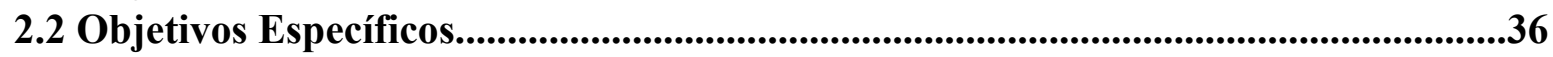

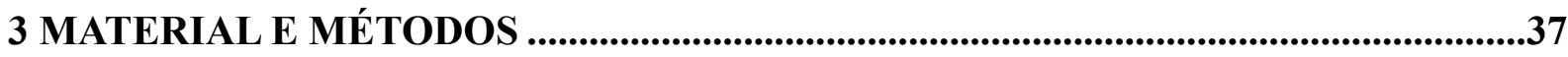

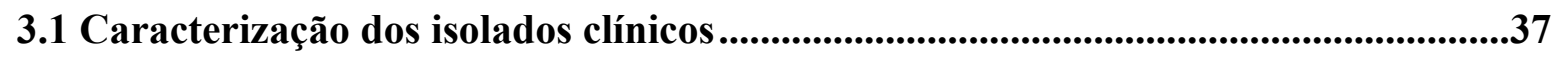

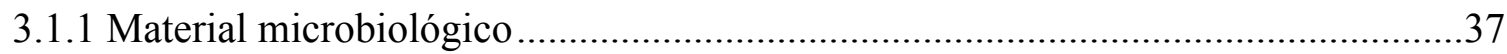

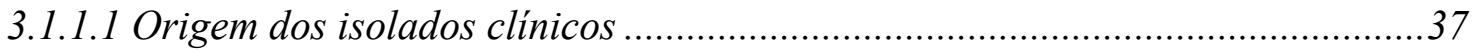

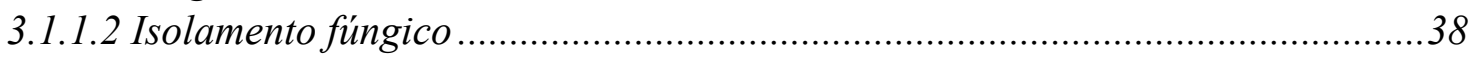

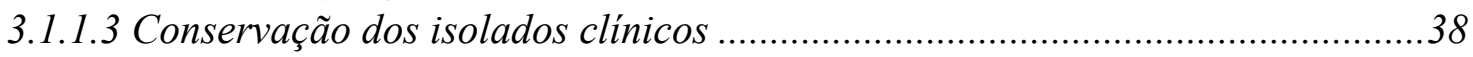

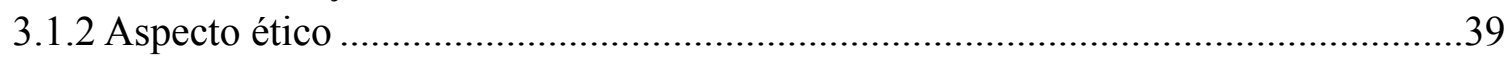

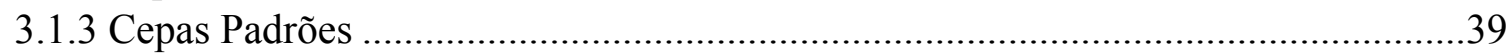

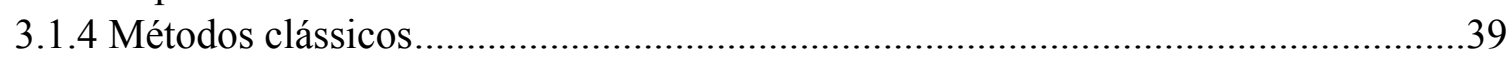

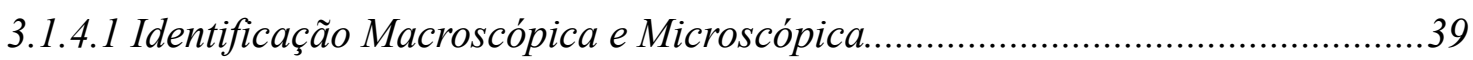

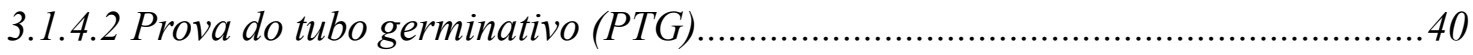

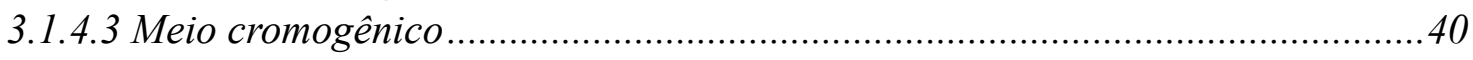

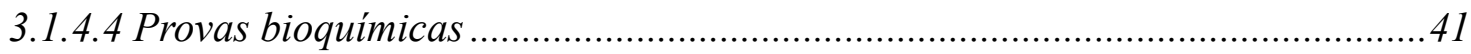

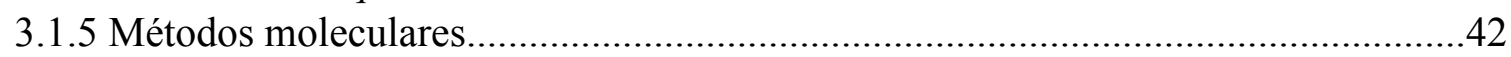

3.1.5.1 Reação em Cadeia da Polimerase multiplex (PCR multiplex)...........................42

3.1.5.2 Reação em Cadeia da Polimerase associada à Restriction Fragment Length

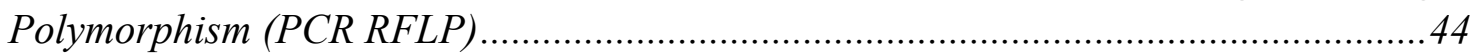

3.1.5.3 Espectrometria de massas (MS) e Matrix Assisted Laser Desorption Ionization

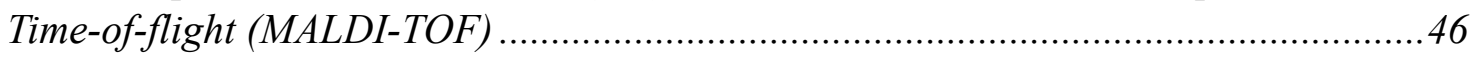

3.2 Determinação do perfil de susceptibilidade dos isolados clínicos...............................46

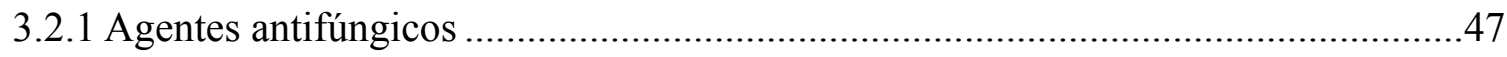

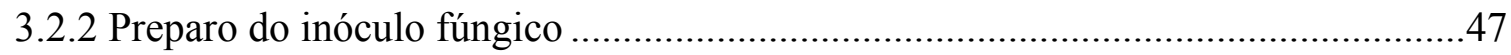

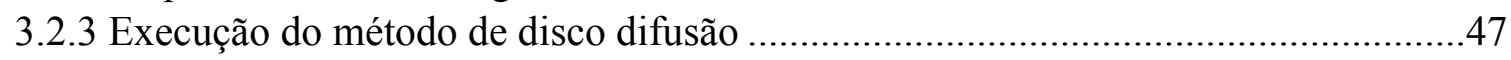

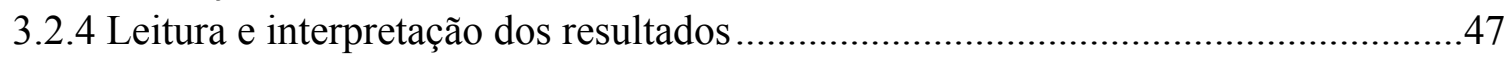


3.3 Avaliação da atividade antifúngica de extratos brutos vegetais................................48

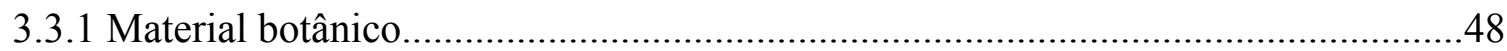

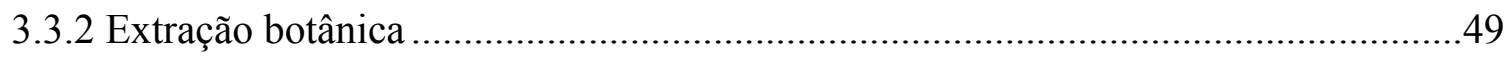

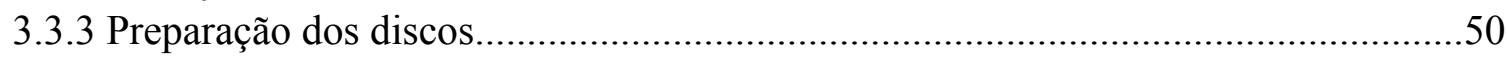

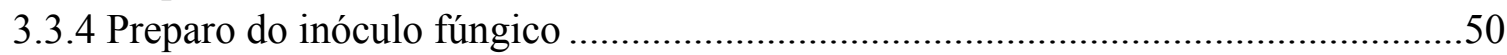

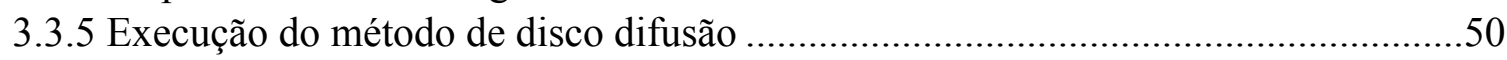

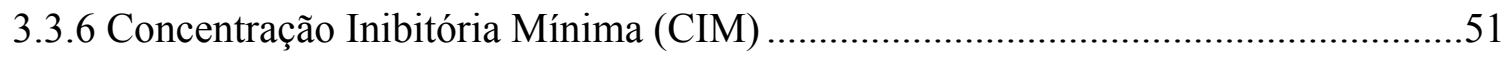

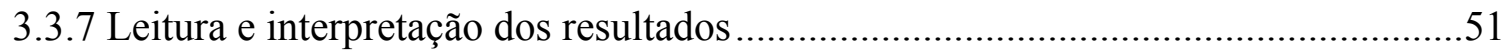

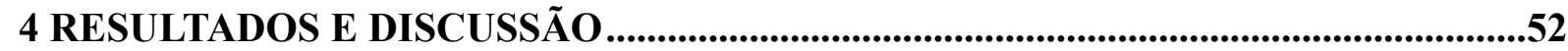

4.1 Identificação dos isolados clínicos por métodos clássicos ......................................52

4.2 Identificação dos isolados clínicos por métodos moleculares ...................................57

4.3 Aspectos epidemiológicos dos isolados clínicos .................................................63

4.4 Perfil de susceptibilidade dos isolados clínicos aos agentes antifúngicos

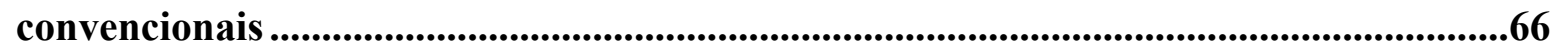

4.5 Atividade antifúngica de extratos brutos vegetais..................................................72

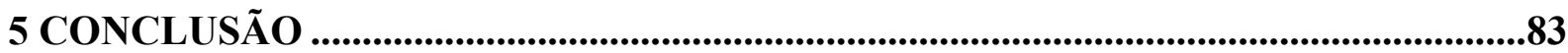

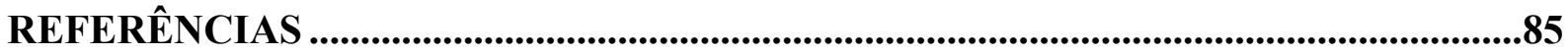

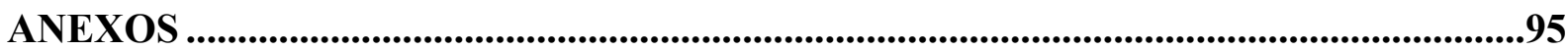




\section{INTRODUÇÃO}

\subsection{0 gênero Candida}

O gênero Candida contém centenas de espécies que apresentam divergências genômicas entre si e variações fenotípicas. As diferenças fenotípicas entre espécies de Candida existem com relação à morfologia, tamanho celular, requisitos de crescimento, composição da parede celular e distribuição de fatores de virulência. Quanto à morfologia, Candida spp. são predominantemente leveduriformes. Muitas espécies deste gênero são dimórficas, ou seja, crescem na forma de leveduras e pseudo-hifas, e Candida albicans, Candida dubliniensis e Candida tropicalis são considerados polimórficos, pois possuem a capacidade de formar leveduras, pseudo-hifas e hifas verdadeiras (WHIBLEY; GAFFEN, 2015).

As formas leveduriformes de Candida spp. possuem tamanhos variáveis, entre 2 a $11 \mu \mathrm{m}$ de diâmetro e consistem em células simples, ovais, que se reproduzem por brotamento (THOMPSON; CARLISLE; KADOSH, 2011; WHIBLEY; GAFFEN, 2015). As pseudo-hifas crescem a partir do brotamento das leveduras, onde os brotos formados permanecem ligados uns aos outros, com constricções na junção e sem a formação de septos. As hifas verdadeiras crescem a partir de pequenos filamentos denominados tubos germinativos, originados de células leveduriformes, que se desenvolvem em direção polarizada, sob orientação de uma organela especializada, o Spitzenkörper, formando estruturas alongadas, interligadas, com lados paralelos, larguras uniformes e septos (Figura 1) (THOMPSON; CARLISLE; KADOSH, 2011). 

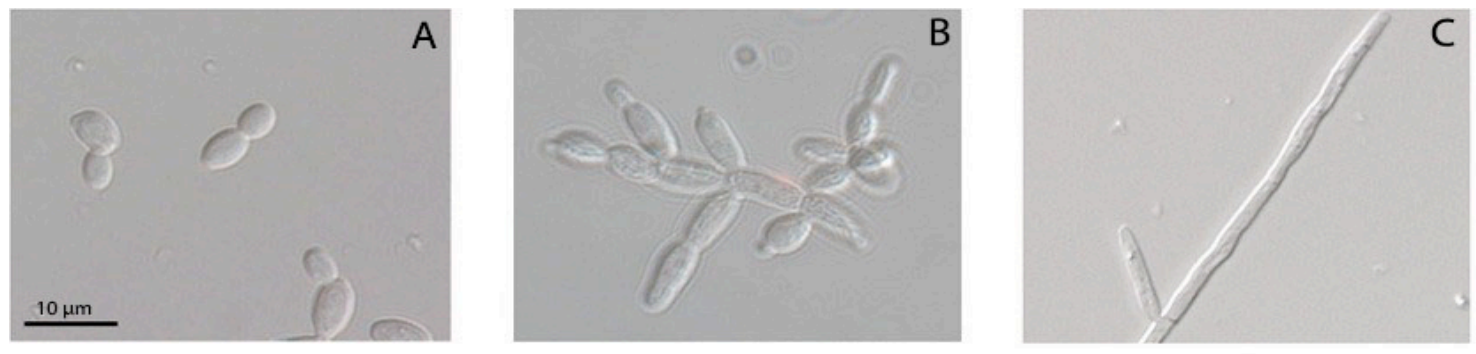

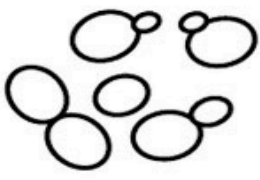

Leveduras

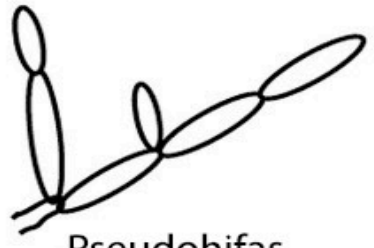

Pseudohifas

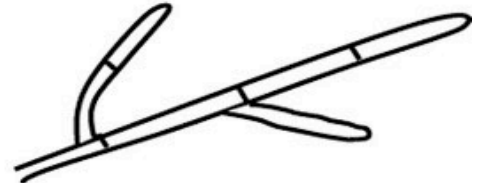

Hifas

Figura 1 - Principais morfologias de patógenos fúngicos humanos

A, B e C - Imagens de células de Candida albicans visualizada por microscopia de contraste de fase e esquema representativo de cada morfologia

Fonte: Adaptado de THOMPSON; CARLISLE; KADOSH, 2011

A transição morfológica entre leveduras e as formas filamentosas (pseudo-hifas e hifas verdadeiras) é regulada por fatores externos associados às condições ambientais, nas quais espécies de Candida confrontam-se com frequência, durante seu ciclo de vida nos hospedeiros. Esses fatores são: componentes do soro humano, $\mathrm{pH}$, elevação de temperatura corpórea $\left(37^{\circ} \mathrm{C}\right)$, baixos níveis de oxigênio, altos níveis de $\mathrm{CO}_{2}$, deficiência nutricional, entre outros. Além destes, alguns fatores internos relacionados às alterações genéticas e epigenéticas de Candida spp., como a via de transdução de sinais e fatores de transcrição, que desempenham importante papel na regulação da morfogênese, também influenciam nessa transformação morfológica (HUANG, 2012). Esta capacidade de Candida spp. de produzir mais de um fenótipo, ou seja, mais de uma morfologia quando exposta a um determinado estímulo, é conhecida como plasticidade fenotípica e representa importante fator de virulência (SOLL, 2002).

Outra forma de transição morfológica é observada entre células leveduriformes de Candida albicans, Candida tropicalis e Candida dubliniensis. A transição denominada "branco-opaco" ocorre em Candida dubliniensis e a transição "branco-cinza-opaco" ocorre em Candida albicans e Candida tropicalis. De modo geral, as leveduras destas espécies de Candida em cultivo, são células pequenas e redondas e formam colônias brancas e brilhantes. Entretanto, ao passarem por alterações morfológicas, as colônias podem apresentar células cinza ou opacas, ou mesmo ambas. As células cinza são pequenas, alongadas e formam colônias cinza e brilhantes, e as células opacas são grandes, alongadas e formam colônias 
cinza, achatadas e ásperas. Além das diferenças morfológicas, estas células diferenciam-se quanto à expressão gênica, reprodução e virulência (TAO et al., 2014).

Como requisitos de crescimento, as espécies de Candida spp. exigem fontes de nitrogênio e fontes de carbono, de preferência carboidratos simples como: D-glicose, sacarose, maltose, trealose, entre outros. Quando requisitados, estes carboidratos são fermentados ou assimilados, ou ambos, e os compostos nitrogenados são assimilados. Tais habilidades, fermentativa e assimilativa, representam a base para a diferenciação e identificação bioquímica de espécies de Candida (LACAZ et al., 1998). Por exemplo, Candida glabrata fermenta e assimila a glicose e apenas fermenta a trealose, Candida guilliermondii fermenta e assimila uma série de açúcares com exceção de maltose e lactose, que são apenas assimiladas. Candida tropicalis também possui a capacidade de fermentar e assimilar vários açúcares, exceto lactose e rafinose e Candida krusei apenas fermenta e assimila a glicose (HOOG et al., 2001).

Em suas estruturas celulares, as espécies de Candida possuem parede celular bem definida, com basicamente, a mesma composição: quitina, polissacarídeos (glucanas e mananas) e proteínas (WHIBLEY; GAFFEN, 2015). No entanto, variações nas proporções destes compostos são evidentes entre as diferentes espécies de Candida (HUANG, 2012).

A parede celular de Candida albicans é constituída de $60 \%$ de $\beta$-glucana e cerca de $40 \%$ de mananoproteínas e quitina (HUANG, 2012). Já a parede de Candida glabrata apresenta $50 \%$ a mais de proteínas, mais mananas e menos glucanas do que Candida albicans, e quantidades maiores de quitina são observadas nas paredes de Candida albicans, Candida tropicalis e Candida parapsilosis, quando comparadas com Candida glabrata e Candida krusei (DE GROOT et al., 2008; COSTA-DE-OLIVEIRA et al., 2013). Além disso, variações proporcionais dos constituintes da parede celular, também são vistas em leveduras e hifas verdadeiras, de uma mesma espécie, como ocorre com as espécies de Candida albicans (GOW et al., 2012).

A patogenicidade de Candida spp. está relacionada a vários fatores de virulência como habilidade de crescimento a $37^{\circ} \mathrm{C}, \mathrm{pH}$ fisiológico, tamanho celular, plasticidade fenotípica, adesão às células dos hospedeiros, formação de biofilmes, tropismo e a produção de enzimas extracelulares (proteinases, fosfolipases, lipase) (MODRZEWSKA; KURNATOWSKI, 2013). Entre estes fatores, a produção de proteinases aspartil secretoras (SAPs) é considerada fator 
crítico e está relacionada com a adesão, invasão e dano tecidual. Além disso, os genes $S A P 1-10$, que codificam estas proteinases, estão distribuídos diferentemente entre as espécies de Candida e também estão envolvidos, de forma distinta, com o desenvolvimento e a manutenção de infecções (SILVA; NERY; DIAS, 2014).

Com relação às proteinases produzidas por espécies de Candida, consta que, em Candida albicans, a produção de SAPs é codificada por dez genes $S A P$, que são agrupados em seis subfamílias: $S A P 1-3, S A P 4-6, S A P 7, S A P 8, S A P 9$ e $S A P 10$. No genoma de Candida tropicalis há uma subfamília de quatro genes, $S A P T 1-S A P T 4$ que codificam as proteinases SAPT1-SAPT4. No genoma de Candida parapsilosis, os genes SAPP1-SAPP3 codificam SAPP1-SAPP3 e oito genes codificadores de SAPs foram encontrados em Candida dubliniensis, SAPCD1-SAPCD4 e SAPCD7-SAPCD10, embora estudos in vitro não tenham identificados a produção das proteinases correspondentes. Em espécies como Candida glabrata, Candida krusei e Candida kefyr, genes SAP ainda não foram detectados em seus genomas (HOYER, 2001; SILVA; NERY; DIAS, 2014).

A heterogeneidade do gênero Candida além de ocorrer entre diferentes espécies de Candida acontece também numa mesma espécie. O complexo parapsilosis, por exemplo, engloba três espécies, com relações próximas, ou seja, mesma morfologia e mesmas características bioquímicas de fermentação e assimilação, no entanto apresentam diferenças genômicas entre si, que as classificam como: Candida parapsilosis stricto sensu, Candida orthopsilosis e Candida metapsilosis. As novas espécies identificadas tem também demonstrado diferenças nas características epidemiológicas e terapêuticas e podem representar potenciais patógenos emergentes no futuro (CRISEO; SCORDINO; ROMEO, 2015).

\subsection{Candidíase sistêmica}

Em hospedeiros humanos saudáveis, Candida spp. são considerados constituintes saprófitas da pele, das mucosas oral, vaginal e intestinal, e do trato respiratório (GHANNOUM et al., 2010; DRELL et al., 2013; FINDLEY et al., 2013; HOFFMANN et al., 2013; NGUYEN; VISCOGLIOSI; DELHAES, 2015). Entretanto, quando ocorrem alterações no mecanismo de defesa do hospedeiro ou comprometimento de barreiras anatômicas, 
Candida spp. tornam-se patogênicas e causam infecções denominadas candidíase (GOW et al., 2012; ILIEV; UNDERHILL, 2013).

A candidíase pode ser subdividida em três principais grupos: candidíase superficial, com ocorrência na pele, pelo e unhas; candidíase de mucosas, envolvendo a orofaringe, esôfago e região vulvovaginal, e candidíase sistêmica, que incluem a candidemia e outras formas de candidíase invasiva (PAPON et al., 2013).

A candidíase sistêmica envolve qualquer sítio anatômico e desta forma possui variedade de manifestações clínicas (PAPPAS, 2006). A forma mais comum de candidíase sistêmica é a candidemia e as formas de candidíase invasiva englobam: candidíase disseminada aguda, infecções endovasculares, osteomielites, artrites, endoftalmites, candidíase disseminada crônica (hepatoesplênica), artrites sépticas, tenossinovite, candidíase renal, candidíase na cavidade intra-abdominal, meningite e raramente pneumonia. A pneumonia é vista quase exclusivamente entre pacientes imunodeprimidos e a meningites ocorrem com frequência, como complicações de candidemia, mas também pode ser considerada em pacientes com dispositivos prostéticos no sistema nervoso central e com desvios intraventriculares (MCCARTY; PAPPAS, 2015).

Em geral, a candidíase sistêmica ocorre em pacientes imunodeprimidos, porém alguns casos são constatados em pacientes imunocompetentes (FIGUEIREDO et al., 2014; OSKI et al., 2014). Os fatores de risco, para candidíase sistêmica, podem ser divididos em dois grupos: fatores relacionados ao hospedeiro e fatores associados a procedimentos de intervenções, que incluem procedimentos cirúrgicos, hemodiálise, longos períodos de hospitalização e uso de cateter, nutrição parenteral, antibióticos e outras drogas intravenosas. Os fatores relacionados ao hospedeiro são doenças imunosupressoras, neutropenia, diabetes, pancreatites, sepses, mucosites, deterioração das condições clínicas devido a doenças de base, extremos de idade, desnutrição e colonização por Candida spp. (MCCARTY; PAPPAS, 2015).

Entre os riscos, não inerentes ao hospedeiro, os mais comuns são os longos períodos de hospitalização e estadias em unidades de terapia intensiva que ocorrem, na maioria das vezes, em combinação com outros fatores, incluindo procedimentos de intervenções invasivas e a colonização por Candida spp. Mesmo com a dificuldade de diferenciar colonização de infecção, relatos indicam que a detecção de colonização em alguma parte do corpo corresponde a fator de risco e não a doença e, portanto, nenhuma forma de tratamento precisa 
ser iniciado. A presença ou ausência de colonização é mais importante no desenvolvimento de candidíase sistêmica do que o número de regiões colonizadas, e independentemente, a ausência de colonização é indicador favorável da exclusão de diagnóstico para candidíase sistêmica (YAPAR, 2014; EGGIMANN et al., 2015).

Nos extremos de idades, a vulnerabilidade à candidíase sistêmica, apresentada por pacientes com mais de 65 anos, está relacionada às mudanças nas funções morfológicas e fisiológicas consequentes da idade, comorbidades, altas taxas de colonização de orofaringe e ao concomitante uso de fármacos (FLEVARI et al., 2013). Nos recém-nascidos, além das alterações fisiológicas associadas à idade, o uso de cateter venoso, nutrição parenteral, longos tratamentos com antibióticos de amplo espectro, baixo peso e malformações congênitas fazem com que estes pacientes desenvolvam defeitos no neurodesenvolvimento e infecções com alto risco de morte. Além disso, candidíase em recém-nascidos apresentam sinais e sintomas não específicos e sutis quando comparadas às infecções invasivas em idosos (SIGMUNDSDÓTTIR et al., 2000; MCCARTY; PAPPAS, 2015).

As principais espécies de Candida associadas à candidíase sistêmica são: Candida albicans, Candida glabrata, Candida parapsilosis, Candida tropicalis e Candida krusei. Estas espécies são responsáveis por $90 \%$ dos casos em todo mundo, embora muitas espécies também estejam associadas a esta infecção, como Candida lusitaniae, Candida guilliermondii, Candida kefyr, Candida norvegensis, Candida dubiniensis, Candida lipolytica, Candida pelliculosa, Candida dublinensis, entre outras. O agente etiológico mais frequente ainda é Candida albicans, representando cerca de 40 a 50\% dos casos, entretanto, Candida não albicans tem demonstrado percentual maior que 50\% no contexto atual (PFALLER et al., 2015).

A prevalência de espécies de Candida varia consideravelmente de acordo com sua distribuição geográfica, centro - a - centro e unidade - a - unidade e esta distribuição é importante em todas as formas de candidíase. $\mathrm{Na}$ verdade, candidíase não é uma, mas várias doenças, com cada espécie de Candida apresentando suas próprias características com relação ao tropismo aos tecidos, propensão de causar doenças invasivas, virulência e susceptibilidade a antifúngicos (MCCARTY; PAPPAS, 2015).

Entre tendências marcantes, Candida albicans é a espécie mais comum em todo o mundo e é isolada de diferentes sítios anatômicos em infecções sistêmicas. Candida glabrata 
é mais proeminente na América do norte do que na América Latina, apresenta alta prevalência em pacientes idosos e tem surgido como importante patógeno hospitalar, representando a segunda ou terceira espécie em casos de candidemia. Candida parapsilosis é mais comum na América do norte do que na Europa e representa importante agente de candidemia, com ocorrência elevada em crianças e recém-nascidos prematuros, e ainda está associada à presença de cateter venoso central e uso de nutrição parenteral (PFALLER et.al., 2010; COLOMBO et al., 2013).

Candida tropicalis é frequentemente isolado na Ásia - Pacífico e menos comum no resto do mundo e representa potencial agente oportunista no caso de hospedeiro neutropênico, e quando há supressão da microbiota bacteriana devido ao uso de antibióticos e a danos na mucosa do trato gastrointestinal. Além disso, Candida tropicalis é a segunda ou terceira espécie mais comum em candidemia de pacientes com câncer (leucemia) e ocorre com menos frequência em pacientes com tumores sólidos (PFALLER et.al., 2010; COLOMBO et al., 2013).

Candida krusei é patógeno hospitalar ocasional, particularmente isolado de pacientes com doenças hematológicas e pacientes transplantados. Sua elevada ocorrência em pacientes neutropênicos com candidemia deve-se à exposição a fluconazol, pois esta espécie apresenta resistência intrínseca a este antifúngico. As demais espécies de Candida, potenciais patógenos de candidíase sistêmica, também apresentam peculiares características epidemiológicas e terapêuticas (PFALLER et al., 2010; COLOMBO et al., 2013).

\subsubsection{Diagnóstico laboratorial}

Candidíase sistêmica compreende, síndromes clínicas de diferentes gravidades, com sinais e sintomas que variam de silenciosos a atípicos ou podem ser confundidos com as manifestações clínicas de outras infecções. Desta forma, seu diagnóstico representa grande desafio e requer evidências clínicas, bioquímicas e microbiológicas (FLEVARI et al., 2013).

No diagnóstico microbiológico, a identificação correta de Candida spp. é o principal objetivo, assim como a utilização de métodos rápidos e confiáveis, que garantam melhores resultados aos pacientes. A abordagem no diagnóstico microbiológico de candidíase sistêmica 
envolve, geralmente, métodos clássicos, no entanto, métodos moleculares têm sido, cada vez mais, introduzidos na rotina clínica laboratorial (WILLINGER; HAASE, 2013).

Os métodos clássicos incluem a detecção microscópica de estruturas fúngicas em amostras clínicas, isolamento fúngico em meios de cultura, caracterização micromorfológica, provas bioquímicas e provas sorológicas. Devido à limitada susceptibilidade e especificidade destes métodos, combinações entre eles são necessárias. No entanto, nem sempre é possível aplicar todos os métodos em todos os casos (WILLINGER; HAASE, 2013).

A detecção microscópica realizada em amostras biológicas é considerado método de triagem, pois indica a presença de formas celulares de Candida spp. (leveduras, pseudo-hifas e hifas), sugerindo provável infecção. Neste procedimento, a solução mais utilizada é o hidróxido de potássio $(\mathrm{KOH})$ de 10 a $20 \%$, cuja função é degradar os componentes protéicos presentes nas amostras biológicas, deixando as células fúngicas intactas e permitindo assim sua visualização. Outras soluções também podem ser utilizadas, como o lactofenol com azul de algodão, que se diferencia do $\mathrm{KOH}$ por corar as células de azul e o branco de calcoflúor, que produz fluorescência da quitina presente na parede celular fúngica (WILLINGER; HAASE, 2013).

$\mathrm{O}$ isolamento fúngico é geralmente executado após, ou em paralelo, à detecção microscópica. A finalidade deste procedimento é obter colônias de Candida spp., a partir de seu crescimento em meios de cultura, para posteriormente serem utilizadas na identificação, realizada por técnicas adequadas. No isolamento primário de Candida spp. é empregado ágar Sabouraud dextrose com cloranfenicol, que é incubado à temperatura de 25 a $30^{\circ} \mathrm{C}$, com variação de $\pm 1^{\circ} \mathrm{C}$, entre 24 a 48 horas (WILLINGER; HAASE, 2013; ZAITZ et al., 2010). Em amostras de sangue, o isolamento fúngico é padrão ouro para o diagnóstico de candidemia, mesmo com atraso considerável em sua realização e baixa positividade (ARVANITIS et al., 2014).

Os sistemas comerciais comumente utilizados no cultivo de amostras de sangue são o Bactec ${ }^{\circledR}$ e Bac/TAlert ${ }^{\circledR}$, que apresentam tempo médio de detecção de 14 a 38 horas, podendo chegar a 72 horas. Nestes sistemas, os meios de cultura aeróbios demonstram melhor crescimento de Candida spp. do que os meios anaeróbios e a utilização de meios específicos para fungos não melhora o rendimento do diagnóstico (ARVANITIS et al., 2014). Em outras 
amostras biológicas, como o líquido cefalorraquidiano, o isolamento fúngico de Candida spp. apresenta baixa susceptibilidade (WILLINGER; HAASE, 2013).

Meios cromogênicos são utilizados tanto no isolamento como na identificação presuntiva de espécies de Candida. Baseiam-se na detecção da atividade enzimática, através da hidrólise de um substrato cromogênico específico na presença de um indicador, demonstrando variações de cores. Comercialmente, existem vários meios disponíveis, CHROMagar Candida ${ }^{\circledR}$, Candida ID $\AA$, Candida ID 2 ${ }^{\circledR}$, CHROMagar-PAL $\AA$, Brilliance Candida Agar ${ }^{\circledR}$, Colorex $\AA$, Cromógena albicans $\AA$, Albicans ID2 $\AA$, Candiselect $\AA$, Fluoroplate ${ }^{\circledR}$ e Agar SDCA-MUAG ${ }^{\circledR}$. O sistema mais utilizado é o CHROMagar Candida ${ }^{\circledR}$, onde são detectadas espécies de Candida albicans, Candida tropicalis e Candida krusei (CORONADO-CASTELLOTE; JIMÉNEZ-SORIANO, 2013).

Quanto à susceptibilidade e especificidade dos métodos cromogênicos, CHROMagar Candida ${ }^{\circledR}$ e Candida ID ${ }^{\circledR}$ oferecem bons padrões, uma vez que permitem a identificação presuntiva da maioria das espécies de Candida. Além disso, são simples, acessíveis e fáceis de usar (CORONADO-CASTELLOTE; JIMÉNEZ-SORIANO, 2013).

Após a obtenção de colônias em meios sólidos, procede-se a identificação de Candida, ao nível de espécies, que comumente é realizada utilizando provas bioquímicas de assimilação e fermentação de carboidratos disponíveis na forma de kits comerciais, manuais ou semiautomatizados. A capacidade destes kits de identificar diferentes espécies de Candida dependem do tipo e número de substratos bioquímicos e também da qualidade e quantidade de dados que compõem bancos de dados, que serão utilizados para gerar limiares e algoritmos (PINCUS; ORENGA; CHATELLER, 2007).

Os principais métodos manuais, para a identificação bioquímica, utilizados na rotina laboratorial clínica são: Uni-Yeast-Tek ${ }^{\circledR}$ que detectam reações de assimilações de sete compostos de carbono, urease, assimilação de $\mathrm{KNO}_{3}$ e crescimento em ágar corn meal. Fungifast ${ }^{\circledR}$ contêm 10 testes, incluindo 6 envolvendo carboidratos e 4 enzimas. Fungichrom $\mathbb{}$ que constitui de 16 testes incluindo 7 carboidratos, 8 enzimas e teste de resistência a cicloheximidina. Auxacolor ${ }^{\circledR}$ capaz de detectar reação de assimilação de 13 carboidratos, resistência a cicloheximidina e produção de fenoloxidase. API 20C AUX® que contêm 19 reações de assimilação de carbono, e entre os métodos semiautomatizados, destacam-se o painel de identificação de leveduras do sistema MicroScan ${ }^{\circledR}$ e o cartão bioquímico para 
leveduras do Vitek ${ }^{\circledR}$, ambos com 27 reações colorimétricas (PINCUS; ORENGA; CHATELLER, 2007).

Para algumas espécies de Candida, como Candida albicans, testes tradicionais de identificações presuntivas ainda são utilizados rotineiramente, mesmo com suas limitações. A prova do tubo germinativo identifica Candida albicans quando leveduras são inoculadas em soro ou plasma, a $37^{\circ} \mathrm{C}$ por até 3 horas e a formação de clamidoconídios por Candida albicans que é observada em meios de cultura ricos em amido, como ágar fubá acrescido de Tween 80 ou meio corn meal. (KONEMAN et al., 2001; PINCUS; ORENGA; CHATELLER, 2007; MEZZARI; FUENTEFRIA, 2012).

As provas sorológicas que detectam antígenos e anticorpos possuem reduzido potencial de diagnóstico para candidíase sistêmica, pois sua positividade nem sempre confirma a presença de infecção e resultados negativos não descartam a possibilidade de processos infecciosos. $\mathrm{O}$ valor preditivo relativamente baixo destas provas deve-se à baixa susceptibilidade, ao limitado valor diagnóstico em pacientes imunodeprimidos e além disso, estas provas não são capazes de diferenciar colonização de infecção (ZAITZ et al., 2012).

No entanto, algumas técnicas sorológicas tem sido utilizadas, teste de aglutinação em

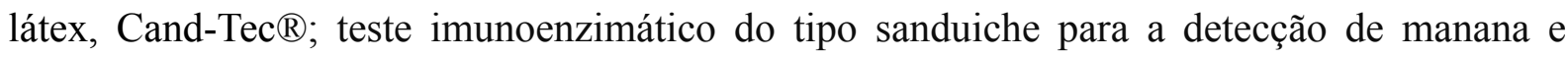
anticorpos anti-manana, Platelia Candida Antigen ${ }^{\circledR}$ e Platelia Candida Antibody ${ }^{\circledR}$; teste de imunofluorescência indireta para a detecção de anticorpos contra estruturas do tubo germinativo de Candida albicans, CAGTA® e vários sistemas comerciais colorimétricos que medem a concentração de ß-glucana como Fungitec-G®; Fungitell®; Wako-WB003® e B-G Star® (MAYR; LASS-FLÖRL, 2011).

Os métodos moleculares representam potenciais ferramentas de diagnóstico microbiológico para candidíase sistêmica, por apresentarem alta acurácia, susceptibilidade e especificidade. No entanto, o uso destes métodos na rotina clínica laboratorial limita-se à falta de padronização e validação. Vários procedimentos têm sido propostos para detectar e diferenciar espécies de Candida, incluíndo métodos baseados na reação em cadeia da polimerase (PCR) e métodos não baseados em PCR (ARVANITIS et al., 2014).

Com relação à técnica de $\mathrm{PCR}$, destacam-se a Restriction Fragment Length Polymorphism (PCR RFLP) que consiste na caracterização de sítios de restrições dos produtos de PCR (PINCUS; ORENGA; CHATELLER, 2007); PCR multiplex que se baseia 
no uso de primers específicos para a amplificação de regiões que são conservadas entre diferentes gêneros fúngicos, e possui a capacidade de detectar várias espécies na mesma amostra (ARVANITIS et al., 2014). PCR nested que utiliza pares de primers para amplificação do DNA, em duas sucessivas corridas de PCR (NEPPELENBROEK et al., 2014). Real Time PCR (qPCR) que permite a quantificação da amplificação do DNA, e recentemente, foi autorizado por Food and Drug Administration (FDA), T2Candida ${ }^{\circledR}$, método baseado na combinação de espectroscopia de ressonância magnética nuclear e amplificação por PCR, seguida de hibridização de nanopartículas que observa o sinal em T2 (ARVANITIS et al., 2014).

Entre os métodos não baseados em PCR, destacam-se a Peptide Nucleic Acid Fluorescent in situ Hybridization (PAN-FISH) que emprega sondas de peptídeos de ácidos nucleicos específicas, para a sequência de rRNA, combinados com análises quantitativas por microscopia fluorescente, e espectrometria de massas com Matrix Assisted Laser Desorption Ionization Time-of-flight (MALDI-TOF) que produz espectros de proteínas característicos de cada espécie, que funciona como impressão digital (Fingerprinting), que são comparados a espectros depositados em bancos de dados. Estes dois métodos também foram, recentemente, autorizados pelo FDA, para o uso em laboratório clínico (NEPPELENBROEK et al., 2014; MCCARTY; PAPPAS, 2015).

\subsubsection{Tratamento}

Os agentes antifúngicos, disponíveis para o tratamento de candidíase sistêmica, pertencem à classe dos poliênicos (anfotericina $\mathrm{B}$ ); dos azólicos, em particular os triazólicos

(fluconazol, itraconazol, voriconazol, posaconazol e isavuconazol); das equinocandinas (caspofungina, micafungina e anidulafungina) e dos análogos de pirimidina (5-fluorocitosina) (McCARTY; PAPPAS, 2015).

Os alvos terapêuticos para estes agentes incluem o ergosterol, esterol presente na membrana citoplasmática fúngica, que sofre ação direta ou indireta de poliênicos e azólicos. A glucana, principal composto da parede celular fúngica, que constitui alvo metabólico explorado pelas equinocandinas e ácidos nucléicos, cuja síntese é inibida por 5-fluorocitosina (MORACE; PERDONI; BORGHI, 2014). 
Entre os poliênicos, anfotericina B é a droga de escolha para as formas severas e invasivas de candidíase e apresenta atividade fungicida contra várias espécies de Candida (COLOMBO et al., 2013). Este agente demonstra propriedades anfipáticas,que permitem sua intercalação entre a membrana contendo ergosterol, induzindo a formação de poros. Os poros formados danificam as funções de barreira da membrana e alteram a permeabilidade da célula, ocorrendo o estravassamento de constituintes citoplasmáticos e consequente morte celular (BAGINSKI; CZUB, 2009).

Resistência adquirida a anfotericina $\mathrm{B}$, entre as espécies de Candida, é rara e a resistência intríseca é observada em Candida lusitaniae. Possivelmente as causas de resistência à anfotericina $\mathrm{B}$ está relacionanda à ausência total de ergosterol na membrana fúngica; estruturas diferentes do ergosterol, que impedem a ligação com os poliênicos ou a alteração na via biossintética do ergosterol, que conduz à substituição do ergosterol por outros esteróis, com menor afinidade pelos poliênicos (MORACE; PERDONI; BORGHI, 2014).

Os azólicos, maior classe terapêutica, dividem-se em imidazólicos e triazólicos. Os triazólicos apresentam atividades fungicida ou fungistática contra muitas espécies de Candida e subdividem em: triazólicos de primeira geração, itraconazol e fluconazol, e triazólicos de segunda geração, voriconazol, posaconazol e isavuconazol (COLOMBO et al., 2013).

O mecanismo de ação dos azólicos consiste na inibição da enzima lanosterol 14- $\alpha$ demetilase codificada pelo gene ERG11, que impossibilita a conversão do lanosterol em ergosterol, provocando a redução do ergosterol e a acumulação de 14- $\alpha$-metil-3,6-diol, produto tóxico sintetizado pela enzima $\delta$-5,6-desaturase, codificada pelo gene ERG3. Como consequência, ocorre alterações na função e estrutura da membrana e, por fim, a inibição do crescimento fúngico (SANGUINETTI; POSTERARO;LASS-FLORL, 2015).

A resistência adquirida por espécies de Candida a azólicos é pouco comum e geralmente está associada a tratamentos prolongados. Existem vários mecanismos através dos quais Candida spp. podem adquirir resistência aos azólicos e é importante lembrar que mais de um mecanismo de resistência pode ocorrer em uma dada espécie. As alterações resultantes podem ter efeitos aditivos ou levar ao desenvolvimento de resistência cruzada (PFALLER, 2012).

Em Candida spp., a resistência aos agentes azólicos envolve a indução de bombas de efluxo, que levam à diminuição da concentração do agente antifúngico no alvo terapêutico. As 
bombas de efluxo em Candida spp. são codificadas pelo gene $C D R$ pertencente aos transportadores ATP - Binding Cassette (ABC) Superfamily, que afeta quase todos os fármacos azólicos e, pelo gene $M D R$ pertencente aos transportadores Major Facilitator superfamily (MFS), que são geralmente seletivos para fluconazol (SANGUINETTI; POSTERARO;LASS-FLORL, 2015).

Também envolve inibição ou superexpressão do gene ERG11, ou mesmo ambos. A mutação no gene $E R G 11$, resultante de substituições de aminoácidos da proteína Erg11p, promove a redução da afinidade entre azólicos e sítio enzimático. Este mecanismo está atribuído à resistência intríseca de Candida krusei ao fluconazol e à superexpressão do gene ERG11 o que resulta em taxas não ideais de droga/enzima (MORACE; PERDONI; BORGHI, 2014; SANGUINETTI; POSTERARO;LASS-FLORL, 2015). Outro mecanismo de resistência compreende a mutação no gene $E R G 3$, que impede a conversão do 14- $\alpha$-metil-3,6diol para 14- $\alpha$-metilfecosterol e, com isso a substituição do ergosterol por fecosterol, conduzindo à funcionalidade da membrana fúngica e, portanto, bloqueia o rompimento da membrana pelos azólicos (SANGUINETTI; POSTERARO;LASS-FLORL, 2015).

As equinocandinas (caspofungina, micafungina e anidulafungina), a mais recente classe do arsenal antifúngico, são fungicidas rápidos contra Candida spp. e exercem seus efeitos através da inibição de $\beta$-(1,3)-D-glucana sintase, enzima responsável pela biosíntese de glucana (COLOMBO et al., 2013). O polissacarídeo glucana, componente essencial à parede celular, consiste em monômeros de D-glicose ligados em si por $\beta$-(1,3)-glucana ou $\beta$ - $(1,6)$ glucana. O bloqueio não competitivoda síntese da $\beta$-(1,3)-D-glucana sintase provoca a diminuição da incorporação de glicose no polímero glucano e, por conseguinte, causa a lise da célula fúngica (KATHIRAVAN et al., 2012).

Mutações pontuais, adquiridas ou intrínsecas, em regiões específicas dos genes $F K S$ (FKS1, FKS2 e $F K S 3)$, responsáveis por substituições de aminoácidos de $\beta$-(1,3)-D-glucana sintase, produzem valores elevados de Concentração Inibitória Mínima (CIM), reduzem a susceptibilidade da $\beta$-(1,3)-D-glucana sintase para o agente antifúngico e conferem resistência cruzadas às equinocandinas (ALEXANDER et al., 2013; SANGUINETTI; POSTERARO;LASS-FLORL, 2015).

Espécies de Candida parapsilosis e Candida guilliermondii apresentam alterações na subunidade $F K S$ naturalmente e possuem CIM mais altas quando comparadas com outras 
espécies de Candida. Outro potencial mecanismo de resistência envolve resposta ao estresse celular como tolerância basal aos danos provocados pelas equinocandinas (SANGUINETTI; POSTERARO;LASS-FLORL, 2015).

A 5-fluorocitosina (5FC), análogo de pirimidina fluorada, é um anti metabólico que também desempenha atividade antifúngica contra Candida spp. O uso deste fármaco como monoterapia, é limitado pela presença de resistência intrínseca e pela facilidade de desenvolver resistência durante o tratamento (MORACE; PERDONI; BORGHI, 2014). Desta forma, este agente é utilizado, frequentemente como adjuvante terapêutico, em combinação com anfotericina B, para pacientes com candidíase sistêmica (FLEVARI et al., 2013).

$\mathrm{Na}$ célula fúngica a 5-fluorocitosina inicia sua atividade com a penetração via permease citosina. No interior da célula é convertida a 5-fluorouracil (5FU) por citosina desaminase. O 5FU é convertido por UMP-pirofosforilase em ácido 5-fluorouridílico, que é fosforilado e incorporado ao ácido ribonucleico (RNA) fúngico, resultando na inibição da síntese protéica. O 5-fluorouracil também pode ser convertido a 5-fluorodeoxiuridina monofosfato que pode inibir a enzima timidilato sintase, responsável pela síntese de ácido dexoribonucleico (DNA) e do processo de divisão nuclear (GHANNOUM; RICE, 1999).

Vários mecanismos de resistência são observados para 5FC, devido às múltiplas enzimas intracelulares requeridas para a sua ação. Entre os mecanismos são incluídas a mutação ou perda da atividade da permease, enzima codificada pelo gene $F C y 2$; alteração na citosina deaminase, codificada pelo gene $F C y l$ e alteração na enzima UMP-pirofosforilase, codificada pelo gene FURl (MORACE; PERDONI; BORGHI, 2014).

A formação de biofilmes por espécies de Candida também apresentam importante papel no desenvolvimento de resistência aos principais agentes antifúngicos utilizados no tratamento de candidíase sistêmica. Com relação aos azólicos, as células presentes no biofilme são 1000 vezes mais resistentes do que as células planctônicas ou livres, tornando esses agentes antifúngicos, opções terapêuticas ineficazes na presença de biofilmes (TAFF et al., 2013).

A resistência de células do biofilme à anfotericina $\mathrm{B}$ é aproximadamente oito vezes maior do que a resistência de células planctônicas e, neste caso, a resistência depende da idade do biofilme. Comparando a resistência de células presentes no biofilme e planctônicas a equinocandinas, células no biofilmes são de 2 a 20 vezes mais resistentes. Em geral, a 
resistência exibida pelas células presentes no biofilme é multifatorial e diversos mecanismos têm sido associados, como: a presença da matrix extracelular, o status metabólico e fisiológico das células, a presença de células persistentes, o aumento do número de células no biofilmes, expressão diferencial de genes associados à resistência, diferente composição de esteróis e resposta ao estresse (TAFF et al., 2013).

O desenvolvimento de resistência aos agentes antifúngicos convencionais, por Candida spp. representa grande desafio clínico e terapêutico, e requer estratégicas, que evitem a disseminação da resistência fúngica, como já ocorreu com as bactérias, que se encontram disseminadas e fora de controle. Entre essas estratégias, as mais utilizadas consistem na identificação de espécies fúngicas, diagnóstico precoce da infecção, testes de sensibilidade aos antifúngicos, disponibilidade de terapias mais eficazes e desenvolvimento de nova geração de potentes antifúngicos (ANDERSON, 2005; ZAITZ et al., 2010).

Atualmente, muitos dos medicamentos utilizados no tratamento de doenças infecciosas são desenvolvidos a partir de produtos naturais, de forma direta ou indireta, especialmente de plantas medicinais, que apresentam grande variedade de compostos com propriedades terapêuticas e são consideradas importante fonte na obtenção de novos medicamentos. O uso de plantas como matéria prima para fármacos é comum em muitos países e está bem estabelecido nos aspectos culturais e tradicionais de algumas nações (SIMÕES et al., 2007; ASSOB et al., 2011; SATI; JOSHI, 2011).

\subsection{Plantas medicinais}

As plantas têm sido utilizadas para o tratamento de várias doenças por diferentes povos em todo o mundo por milhares de anos. Tradicionalmente, as plantas são utilizadas na forma de fármacos brutos como tinturas, chás e outras formulações, e observações populares de seu uso e eficácia contribuem de forma significativa com a divulgação de suas propriedades terapêuticas, de modo que prescrições de plantas são realizadas com frequência, mesmo sem conhecer os seus constituíntes químicos. Na classificação da medicina moderna, as plantas adquirem status medicinal, pois a presença de compostos farmacologicamente ativos possibilita a sua utilização, a nível terapêutico, conferindo benefícios no tratamento de algumas doenças e também atuando como agente preventivo e profilático (SILVA; 
FERNANDES JÚNIO, 2010; KARAKAS; YILDIRIM; TURKER, 2012; MARTINS et al., 2015).

Centenas de compostos químicos com atividade biológica estão presente em cada planta, trabalhando em sinergismo e conferindo ampla variedade de bioatividades. Entre estas bioatividades, a propriedade antifúngica de muitas plantas medicinais têm sido descrita contra espécies de Candida clinicamente importante tanto in vitro como in vivo (MARTINS et al., 2015). Estudos in vitro com extratos e óleos essenciais de Allium tuberosum, Coriandrum sativum, Cymbopogon martini, Cymbopogon winterianus e Santolina chamaecyparissus indicam atividade antifúngica destes extratos para isolados de Candida spp. da cavidade oral de pacientes com doenças peridontais (FURLETTI et al., 2011). Da mesma forma, óleo essencial de Mentha suaveolens monstra atividade in vitro candidacida e candiostática contra Candida albicans isoladas de candidíase vulvo-vaginal de pacientes com AIDS e, em estudo in vivo, usando o óleo de Mentha suaveolens contra infecção vulvo vaginal de ratos, foi observada a eliminação da Candida albicans nesta infecção (PIETRELLA et al., 2011).

Além da atividade antifúngica de plantas medicinais, estudos para a determinação dos alvos de inibição destes produtos e a ocorrência de sinergismo entre fármacos e plantas têm sido desenvolvidos. Estudo com Allium sativum (alho) para determinar seu efeito na transformação morfologica da Candida albicans (leveduras-hifas) e na expressão gênica de SIR2, gene responsável pelo controle morfogenético, demonstra que o Allium sativum e seus constituintes são capazes de suprimir a produção de hifas (fator de virulência) e afetam a expressão do gene SIR2 (LOW et al., 2008). Da mesma forma, foi observada a produção de estresse oxidativo em Candida albicans por constituintes do Allium sativum (LEMAR et al., 2005).

A ocorrência de sinergismo entre produtos naturais e fármacos foi observada em estudo in vitro realizado por Nweze e Eze (2009), a atividade do extrato etanólico de Ocimium gratisimum L contra Candida albicans foi sinérgica com nistatina e cetoconazol. Bankole e colaboradores (2007) também demonstram atividade sinérgica antimicobiana, porém, através da combinação entre produtos naturais, do Sesame radiatum e Sesame indicum contra Candida albicans.

Estudos realizados em diferentes regiões do Brasil demonstram a diversidade de produtos naturais que apresentam atividade antifúngica. Em extratos de plantas coletadas em 
Santa Catarina, foi observado que a aroeira (Schinus terebinthifolius Raddi), a caapaeba do Pará (Piper regnellii), o malvísco (Herissantia crispa), a amora-preta (Rubus urticaefolius), a azederia (Rumex acetosa) e a carqueja - vassoura (Baccharis dracunculifolia) apresentam atividade inibitória por pelo menos uma das cepas ATCC de Candida spp. testadas (JOHANN et al., 2007). Assim como extratos de Croton urucurana Baill (Sagra d'agua) e Lafoensia pacari St. Hil (Dededeira), plantas típicas do cerrado brasileiro (Mato Grosso), também apresentaram atividade antifúngica contra cepas ATCC de Candida spp. (SILVA JUNIOR et al., 2009).

De fato, a rica flora e a vasta biodiversidade do Brasil, acompanhada pelos aspectos culturais e tradicionais associado ao uso popular de plantas medicinais, mantidos ao longo do tempo, torna o país, importante centro para o desenvolvimento de pesquisa e estudos científicos envolvendo plantas medicinais, tanto no desenvolvimento de novos fármacos como na descoberta de modelos para novas moléculas bioativas (SIMÕES et al., 2007) e entre os principais Biomas Brasileiro, o cerrado é o segundo maior, ocupando $21 \%$ de todo território nacional, concentrando-se principalmente no Planalto Central e é constituido por uma das maiores biodiversidade do mundo com cerca de 7.000 espécies de árvores (KLINK; MACHADO, 2005).

1.3.1 Plantas do cerrado selecionadas para o screening da atividade antifúngica

\subsubsection{Erythroxylum daphinites Mart.}

Erythroxylum daphinites Mart. pertence à família Erytroxylaceae e está distribuída no Brasil nas regiões Norte, Centro - Oeste e Sudeste. Na Bolívia está presente em La Paz e em Santa Cruz, e no Peru em Madre de Díos (PLOWMAN; HENSOLD, 2004). Esta espécie encontra-se na forma de arbusto, medindo de 2,5 a 3 metros de altura e possui folhas oblongo - elípticas, coriáceas e discolores com a face abaxial mais clara (PATRÍCIO; PIRANI, 2002).

Suas folhas apresentam flavonoides como: caempferol 3-arabinosídeo, quercitina 3glucosídeo, quercitina 3-rhamnosídeo e ombuin 3-rutinosídeo (BOHM et al., 1988) e, em estudo recente, foi demonstrado que extratos de folhas de Erythroxylum daphinites exibem efeito citotóxico supra aditivo (sinérgico) quando associado à radiação, em células do 
carcinoma escamoso de cabeça e pescoço. Além disso, o extrato hexânico das folhas pode induzir morte das células do câncer oral por apoptose (ELIAS et al., 2014).

\subsubsection{Erythroxylum subrotundum A. St.-Hil}

Pertencente também à família Erythroxylaceae, Erythroxylum subrotundum A. St.-Hil está distribuída nas regiões Nordeste, Centro Oeste e Sudeste do Brasil. Pode ser encontrada em La Paz (Bolívia) e na Venezuela, cuja espécie correspondente é Erythroxylum christii (PLOWMAN; HENSOLD, 2004). Sua forma de vida é arbustiva com até 3 metros de altura e suas folhas são obovais, raramente elípticas, membranáceas, discolores com a face adaxial lúcida e face abaixal opaca (PATRÍCIO; PIRANI, 2002; LOIOLA et al., 2007).

$\mathrm{Na}$ composição química das folhas de Erythroxylum subrotundum encontram-se, flavonoides (ombuin 3-rutinosídeo) (BOHM et al., 1988), alcaloides como calistegina (BROCK et al., 2005) e cocaína (BIERI et al., 2006), com relação à atividade biológica de extratos de Erythroxylum subrotundum, Elias e colaboradores (2014) indicam efeito citotóxico supra aditivo (sinérgico) em associação com radiação em células do carcinoma escamos de cabeça e pescoço.

\subsubsection{Bauhinia rufa (Bong.) Steud.}

Pertencente à família Leguminosae, Bauhinia rufa (Bong.) Steud. ocorre no Brasil, nos estados de Goiás, Minas Gerais e Distrito Federal (VAZ; TOZZI, 2003) e na Bolívia, na cidade de Santa Cruz (HADJU; HOHMANN, 2012). Apresenta-se na forma de arvoreta, subarbusto ou arbusto e suas folhas são bilobadas, coriácea, com face adaxial glabra, exceto na nervura principalque é pilosa e face abaixal fusco ou ferrugíneo, tomentosa a hirsútula (VAZ; TOZZI, 2003). Em suas folhas foram encontrados óleos voláteis como monoterpenos ( $\alpha$-pinene, $\beta$-pinene, $\alpha$-fenchene) e sesquiterpenos ( $\alpha$-gurjenene, allo-aromadendrene, sinularene, $\alpha$-amorphene, germacrene-D, germacrene-B, bicyclogermacrene, $\partial$-cadinene, viridiflorol, spathielenol, aromadendrene, $\mu$-cadinene, globulol e lepidozenol) (DUARTEALMEIDA, 2004). Popularmente é conhecida como "pata-de-vaca" e utilizada 
tradicionalmente na hiperlipidemia e obesidade (SILVA et al., 2010) ou em doenças renais e diabetes (HADJU; HOHMANN, 2012).

\subsubsection{Pouteria ramiflora (Mart.) Radlk}

Pouteria ramiflora (Mart.) Radlk pertence à família Sapotaceae, está amplamente distribuída na América do Sul e é encontrada no Brasil, no cerrado, na Amazônia e floresta Atlântica. Existe na forma de árvores de 10 a 25 metros de altura, com folhas dispostas em espiral, lanceoladas a oblanceolada, cartácea, glabro para púberes (ALVES-ARAÚJO et al., 2014).

Como atividade biológica foi identificado em extrato etanólico das folhas de Pouteria ramiflora, efeito neuroprotetor contra danos oxidativos, que restaura os níveis de proteína de miosina-Va no cérebro e é capaz de evitar a perda neuronal em regiões do hipocampo de ratos diabéticos após 20 dias de tratamento (COSTA et al., 2013) e extrato etanólico de folhas de Pouteria ramiflora também apresenta efeito inibitório da atividade de tirosinase, enzima responsável pela síntese de melanina (SOUSA et al., 2012).

\subsubsection{Pouteria torta (Mart.) Radlk}

Pertencente à família Sapotaceae, Pouteria torta (Mart.) Radlk está distribuída nas florestas Amazônica e Atlântica (Bahia) e no cerrado. Consiste em árvore de 40 metros de altura, com folhas espiralada, oblanceolada a elíptica, cartácea a coriácea, com face adaxial glabrosa, com centro piloso e, a face abaixal glabrosa a pubescente. Além disso, apresenta margem plana, nervação eucamptódroma (raramente eucamptó-broquidódroma) e pecíolo longo, canalizado, glabroso a piloso (ALVES-ARAÚJO et al., 2014).

Em extrato hexânico das folhas de Pouteria torta foi identificado lupeol (PERFEITO et al., 2005). Em extrato etanólico das folhas de Pouteria torta foram isolados flavonides (GOUVEIA et al., 2013) e em extrato aquoso das folhas de Pouteria torta foram identificados derivados de catequinas, derivados de ácidos gálico e myricitrina (falvonide) (SOUSA et al., 2012). Diferentes extratos das folhas de Pouteria torta têm variáveis atividades biológicas como: atividade inibitória (in vitro) de alfa-amilase (GOUVEIA et al., 2013), atividade 
antibacteriana e antifúngica (ALVES et al., 2000) e efeito inibitório da atividade de tirosinase (SOUSA et al., 2012). Popularmente esta espécie de planta é conhecida como "guapeva", “curiola", "acá ferro", “abiu do cerrado" e "grão de galo" (PERFEITO et al., 2005).

\subsubsection{Eugenia dysenterica Mart. DC}

Eugenia dysenterica Mart. DC pertence à família Myrtaceae e está distribuída em toda a extensão do cerrado, em vários Estados Brasileiros, sendo comum o seu predomínio na Bahia, Distrito Federal, Goiás, Maranhão, Mato Grosso, Mato Grosso do Sul, Minas Gerais, Pará, Piauí, São Paulo e Tocantins (LORENZI et al., 2002; OLIVEIRA et al., 2015). Encontra-se na forma de árvore, com cerca de 10 metros. As folhas são membranáceas, aromáticas, simples, oposta-cruzadas, ovada-elíptica, elípticas a oblongo-elíptica, glabras quando na maturidade e pubérulas quando jovens, com brilho na face superior, coriáceas, curto pecioladas a subsésseis. Apresentam tricomas esbranquiçados; ápice ligeiramente acuminado, caudado a agudo, raro apiculado ou ligeiramente emarginado; nervuras médias plana-sulcadas na porção proximal passando a levemente saliente na porção distal da face adaxial, glabra a pubérula em ambas as faces e nervuras laterais (LORENZI et al., 2002; SILVA; CHAVES; NAVES, 2001).

Entre os componentes químicos, já descritos estão: taninos, flavonoides, catequinas, ácido gálico, sesquiterpenos e componentes voláteis como os óleos essenciais ( $\beta$-cariofileno, $\alpha$-humuleno, limoneno, $\alpha$-tujeno, $\alpha$-terpineol e óxido de $\beta$-cariofileno, $\alpha$-pineno, (Z)- $\beta$ ocimeno, (E)- $\beta$-ocimeno, e $\gamma$-cadineno) (SOUSA et al., 2012; CECÍLIO et al., 2012; DUARTE et al., 2010; COSTA et al., 2000). Popularmente, Eugenia dysenterica é conhecida como "cagaita" ou "cagaiteira" e suas folhas são utilizada tradicionalmente como antidiarréica; na diabetes e icterícia (LIMA et al., 2011).

As atividades biológicas de diferentes extratos das folhas de Eugenia dysenterica indicam, atividade antidiarréica (LIMA et al., 2011), efeito inibitório de $\alpha$-amilase e inibição total de $\alpha$-glucosidase (SOUSA et al., 2012), atividade antioxidante (PRADO et al., 2014), atividade antifúngica (COSTA et al., 2000), atividade antiviral (CECÍLIO et al., 2012) e efeito gastroprotetor associado à inibição da produção de HCL (PRADO et al., 2014). 


\section{OBJETIVOS}

\subsection{Objetivo Geral}

Caracterizar isolados clínicos de Candida spp., quanto à epidemiologia, genética e perfil de susceptibilidade aos agentes antifúngicos convencionais e avaliar a atividade biológica de extratos brutos de plantas do cerrado brasileiro frente a estes microrganismos, na busca de potenciais agentes antifúngicos.

\subsection{Objetivos Específicos}

Identificar, espécies de Candida, por métodos clássicos morfológicos, cromogênicos e bioquímicos.

Confirmar, por métodos moleculares, a identificação fenotípica das espécies de Candida, utilizando Reação em Cadeia da Polimerase multiplex (PCR multiplex) e Reação em Cadeia da Polimerase associada a Restriction Fragment Length Polymorphism (PCR RFLP).

Confrontar a acurácia da técnica de espectrometria de massas Matrix Assisted Laser Desorption Ionization Time-of-flight (MALDI-TOF), com as técnicas moleculares, para identificação das espécies de Candida.

Determinar o perfil de susceptibilidade de Candida spp. frente à voriconazol, fluconazol, itraconazol, anfotericina B e 5-fluorocitosina, empregando o método de disco difusão

Testar extratos brutos de plantas do cerrado brasileiro, quanto à atividade antifúngica contra Candida spp., por método de disco difusão. 


\section{MATERIAL E MÉTODOS}

\subsection{Caracterização dos isolados clínicos}

\subsubsection{Material microbiológico}

\subsubsection{Origem dos isolados clínicos}

Foram estudados 150 isolados clínicos provenientes de cultivos de materiais biológicos, realizados pelo Núcleo de Parasitologia e Micologia (NPM) do Laboratório Central de Saúde Pública do Distrito Federal (LACEN-DF) no período de Janeiro/2011 a Dezembro/2012.

Os materiais biológicos cultivados foram: lavado broncoalveolar $(n=54)$, sangue $(n=40)$, escarro $(n=30)$, fragmento de tecido $(n=7)$, urina $(n=7)$, líquor $(n=5)$, secreções $(n=4)$, líquidos corporais $(n=2)$ e ponta de cateter $(n=1)$. Estes materiais foram coletados de pacientes com idade entre 0 a 20 anos $(n=24) ; 21$ a 60 anos $(n=79)$ e acima de 60 anos $(n=47)$, com variação da faixa etária de 0 a 98 anos e média de idade 46,7 anos. Foi observado também que 100 pacientes eram do sexo masculino e 50 do sexo feminino (Tabela 1).

$\mathrm{O}$ envio dos materiais biológicos ao LACEN-DF foi realizado pelas seguintes unidades de saúde da rede pública do Distrito Federal: Hospital de Base do Distrito Federal (HBDF); Hospital Regional da Asa Norte (HRAN); Hospital Regional da Asa Sul (HRAS); Hospital Regional do Guará (HRGu); Hospital Regional de Taguatinga (HRT); Hospital Regional de Ceilândia (HRC); Hospital Regional de Samambaia (HRSam); Hospital Regional de Brazlândia (HRBz); Hospital Regional do Gama (HRG); Hospital Regional de Sobradinho (HRS); Hospital Regional de Planaltina (HRPl); Hospital Regional do Paranoá (HRPa); Hospital Universitário de Brasília (HUB); Hospital das Forças Armadas (HFA) e Hospital de Apoio de Brasília (HAB). 
Tabela 1 - Materiais biológicos coletados e características da população em estudo

\begin{tabular}{|c|c|c|}
\hline Aspectos analisados & Número & $\%$ \\
\hline \multicolumn{3}{|l|}{ Materiais biológicas } \\
\hline Lavado broncoalveolar & 54 & 36 \\
\hline Sangue & 40 & 27 \\
\hline Escarro & 30 & 20 \\
\hline Fragmento de tecido & 7 & 5 \\
\hline Urina & 7 & 5 \\
\hline Líquor & 5 & 3 \\
\hline Secreções & 4 & 2 \\
\hline Líquidos corporais & 2 & 1,3 \\
\hline Ponta de cateter & 1 & 0,7 \\
\hline Total & 150 & 100 \\
\hline \multicolumn{3}{|l|}{ Idade } \\
\hline $0-20$ & 24 & 16 \\
\hline $21-60$ & 79 & 53 \\
\hline Acima de 60 & 47 & 31 \\
\hline Total & 150 & 100 \\
\hline \multicolumn{3}{|l|}{ Gênero } \\
\hline Feminino & 50 & 33 \\
\hline Masculino & 100 & 67 \\
\hline Total & 150 & 100 \\
\hline
\end{tabular}

\subsubsection{Isolamento fúngico}

A obtenção dos isolados clínicos foi realizada a partir de cultivos de materiais biológicos a $25^{\circ} \mathrm{C}\left( \pm 2^{\circ} \mathrm{C}\right)$ em tubos de ágar Sabouraud dextrose com cloranfenicol (HiMedia, Mumbai, Índia) e ágar Niger (HiMedia, Mumbai, Índia) e, a $35^{\circ} \mathrm{C}\left( \pm 2^{\circ} \mathrm{C}\right)$ em tubos de ágar Infusão de Cérebro e Coração (BHIA) (Merck, Darmstadt, Alemanha) e ágar Fava Neto. O período de incubação para o cultivo de materiais biológicos associadas à micose sistêmica foi de 30 dias, no entanto, o crescimento de leveduras foi observado até 72 horas (LARONE, 1995).

\subsubsection{Conservação dos isolados clínicos}

Os isolados clínicos foram conservados em água destilada estéril em tubos de micro centrifugação de $2,0 \mathrm{~mL}$ à temperatura de $20^{\circ} \mathrm{C}$ negativo, para recuperação e processamento posterior (NEUFELD, 1999). 


\subsubsection{Aspecto ético}

Este estudo foi aprovado pelo parecer no 639/2011 do Comitê de Ética em Pesquisa da Secretaria de Estado de Saúde do DF (CEP/SES-DF) (ANEXO).

\subsubsection{Cepas Padrões}

Foram utilizados, cepas padrões de Candida guilliermondii (ATCC 6260), Candida tropicalis (ATCC 28707), Candida parapsilosis (ATCC 22019), Candida albicans (ATCC 90028), Candida glabrata (ATCC 2001), Candida famata (ATCC 62894) e Candida krusei (ATCC 34135) cedidas gentilmente pela Fundação Osvaldo Cruz do Rio de Janeiro (FIOCRUZ-RJ).

\subsubsection{Métodos clássicos}

Para a identificação fenotípica, os isolados clínicos foram subcultivados em tubos de ágar Sabouraud dextrose com cloranfenicol (HiMedia, Mumbai, Índia) a $35^{\circ} \mathrm{C}\left( \pm 2^{\circ} \mathrm{C}\right)$ por 24 a 48 horas, até que ocorresse crescimento adequado (LARONE, 1995). A partir de colônias frescas e puras, foram observadas as características macroscópicas e microscópicas e foram realizadas a prova do tubo germinativo (PTG), a identificação presuntiva em meio cromogênico e provas bioquímicas, baseadas em reações enzimáticas e colorimétricas, utilizando sistema semiautomatizado.

\subsubsection{Identificação Macroscópica e Microscópica}

A identificação macroscópica foi realizada a partir da visualização das colônias em ágar Sabouraud dextrose com cloranfenicol em tubos de vidro (HiMedia, Mumbai, Índia) após 48 horas de incubação a $35^{\circ} \mathrm{C}$ e para a identificação microscópica, uma a duas colônias foram dissolvidas em 1 gota de lactofenol azul de algodão (Newprov, Pinhais, PR, Brasil), previamente colocada sobre lâmina para microscopia e, em seguida, cobertas com lamínula. 
A preparação de lâmina e lamínula foi observada no microscópio óptico com aumento de 400X, a fim de visualizar e caracterizar as estruturas leveduriformes (LARONE, 1995).

\subsubsection{Prova do tubo germinativo (PTG)}

A prova do tubo germinativo foi realizada com o propósito de diferenciar Candida albicans (PTG positivo) de espécies de Candida não albicans (PTG negativo) (TASCHDJIAN et al., 1959). Para isto, cerca de quatro colônias com 24 horas de crescimento foram inoculadas em $0,5 \mathrm{~mL}$ de soro humano contidos em tubos de ensaios e incubados à temperatura de $35^{\circ} \mathrm{C}\left( \pm 2^{\circ} \mathrm{C}\right)$ por 3 horas. A produção de projeções alongadas, denominadas “Tubo Germinativo", foi observada no microscópio óptico (400X), utilizando preparações com lâminas e lamínulas (LARONE, 1995). Para esta prova, foi empregada cepa de referência American Type Culture Colletion (ATCC) de Candida albicans ATCC 90028 como controle positivo.

\subsubsection{Meio cromogênico}

Foi utilizado para identificar, de forma presuntiva, Candida albicans, Candida tropicalis e Candida krusei, meio cromogênico em placas. Estas espécies de Candida produzem colônias de diferentes cores ao reagirem com os substratos cromogênicos presentes no meio. As colônias de Candida albicans aparecem com coloração verde clara a verde médio, as colônias de Candida tropicalis são azul esverdeada a azul metalizada, com ou sem halo violeta, e as colônias de Candida krusei são cor de rosa claro a vermelho claro com rebordo esbranquiçado. A presença de colônias com outras colorações foram atribuídas as outras espécies de leveduras do gênero Candida como: Candida parapsilosis, Candida guilliermondii, Candida famata, Candida glabrata, entre outras. No entanto, estas espécies não foram identificadas por este método (ODDS; BERNAERTS, 1994).

O uso do meio cromogênico para identificação de Candida spp. procedeu da seguinte forma: inicialmente, foi preparado inóculo fúngico com turvação equivalente a 0,5 da escala de McFarland ( $1 \times 10^{6}$ a $5 \times 10^{6}$ células $/ \mathrm{mL}$ ) em tubos de ensaio contendo 3,0mL de solução salina estéril a $0,85 \%$. O inóculo foi espalhado no meio de cultura com auxílio de alça de 
inoculação e, em seguida, o meio foi incubado à $35^{\circ} \mathrm{C}\left( \pm 2^{\circ} \mathrm{C}\right)$ por 48 horas. Após período de incubação, as placas foram submetidas a leitura visual, a fim de detectar a presença de colônias de coloração específica para as espécies de Candida. Como controle positivo foram utilizadas cepas de referência de Candida albicans ATCC 90028, Candida tropicalis ATCC 28707 e Candida krusei ATCC 34135.

\subsubsection{Provas bioquímicas}

As provas bioquímicas foram realizadas, utilizando painéis de identificação rápida para leveduras, constituídos por 96 poços de microdiluição com 27 substratos e 2 controles (Tabela 2).

Tabela 2 - Controles e substratos utilizados na identificação bioquímica de leveduras

\begin{tabular}{|c|c|}
\hline Controles & Abreviaturas \\
\hline$\overline{B-N a f t i l a m i d a}$ & BNAC \\
\hline Nitrofenil & NPC \\
\hline Substratos & Abreviaturas \\
\hline Hidroxiprolina- $\beta$-Naftilamida & HPR \\
\hline L-Isoleucina- $\beta-N a f t i l a m i d a$ & ILE \\
\hline L-Prolina- $ß-N a f t i l a m$ & PRO \\
\hline L-Tirosina-ß3-Naftilamida & TYR \\
\hline Glicina-ß-Naftilamida & GLY \\
\hline Glicilglicina- $\beta-N a f t i l a m i d a$ & GGLY \\
\hline 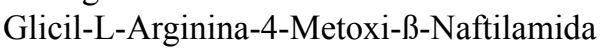 & GLAR \\
\hline Glicil-L-Prolina-4-Metoxi-ß-Naftilamida & GLPR \\
\hline L-Arginil-L-Arginina- $\beta-N a f t i l a m i d a$ & AARG \\
\hline L-Lisil-L-Alanina-4-Metoxi-ß-Naftilamida & LYAL \\
\hline L-Alanina-4-Metoxi-ß-Naftilamida & ALA \\
\hline L-Senil-L-Tirosina- 3 -Naftilamida & STY \\
\hline p-Nitrofenil-N-Acetil-ß-D-Glicosamina & NAG \\
\hline p-Nitrofenil- $\alpha$-D-Glicopiranósido 1 & AGL1 \\
\hline p-Nitrofenil- $\alpha$-D-Glicopiranósido 2 & AGL2* \\
\hline p-Nitrofenil-ß-D-Glicopiranósido & BGL \\
\hline p-Nitrofenil-ß3-D-Galactopiranósido & BGAL \\
\hline p-Nitrofenil-ß3-D-Fucopiranósido & $\mathrm{BDF}$ \\
\hline p-Nitrofenil- $\alpha$-D-Galactopiranósido & AGAL \\
\hline 3-Indoxilfosfato & IDX \\
\hline L-Histidina- $3-N a f t i l a m i d a$ & HIS \\
\hline Sucrose 1 & SUC1 \\
\hline Sucrose 2 & SUC2* \\
\hline Trealose & TRE \\
\hline Ureia & URE \\
\hline
\end{tabular}

(*) Nos substratos SUC1 e SUC2 e AGL1 e AGL2, utilizam-se formulações diferentes dos mesmos substratos. 
$\mathrm{Na}$ preparação dos painéis, foi pipetado $50 \mu \mathrm{L}$ de suspensão fúngica nos poços com substratos e nos poços dos controles. Após inoculação da suspensão fúngica, os painéis foram incubados à temperatura de $35^{\circ} \mathrm{C}\left( \pm 2^{\circ} \mathrm{C}\right)$ sem $\mathrm{CO}_{2}$. Em seguida foi adicionado uma gota $(50 \mu \mathrm{L})$ de reagente peptidase nos poços BNAC, HPR, ILE, PRO, TYR, GLY, GGLY, GLAR, GLPR, AARG, LYAL, ALA, STY e HIS e 1 gota ou $50 \mu \mathrm{L}$ de Hidróxido de Sódio $(\mathrm{NaOH})$ 0,05N aos poços AGL2, BDF, AGAL, NPC, NAG, CELL e NGAL. A leitura foi realizada após 4 horas de incubação.

A avaliação dos resultados das reações enzimáticas colorimétricas, permitiu a identificação da espécie e sua probabilidade relativa cumulativa da identificação. Foram considerados resultados válidos e, portanto, identificação completa das leveduras, quando o percentual de probabilidade foi igual ou maior a $85 \%$. Como controle positivo, foi utilizado cepa de referência de Candida albicans ATCC 90028.

\subsubsection{Métodos moleculares}

As técnicas moleculares empregadas na identificação dos isolados clínicos de Candida spp. foram: Reação em Cadeia da Polimerase multiplex (PCR multiplex), Reação em Cadeia da Polimerase associada a Restriction Fragment Length Polymorphism (PCR RFLP) e espectrometria de massas Matrix Assisted Laser Desorption Ionization Time-of-flight (MALDI-TOF).

As técnicas de PCR foram realizadas no Laboratório de Micologia do Instituto de Higiene e Medicina Tropical da Universidade Nova de Lisboa, Portugal e, a espectrometria de massas foi realizada no Núcleo de Parasitologia e Micologia do LACEN-DF.

\subsubsection{Reação em Cadeia da Polimerase multiplex (PCR multiplex)}

Para a realização da técnica de PCR multiplex, foram utilizados primers universais específicos para leveduras de relevância clínica (UNI1 e UNI2) com o objetivo de amplificar as regiões Internal Transcribed Spacer 1 (ITS1) e 2 (ITS2), incluindo a região 5,8S do ácido ribonucléico ribossômico (rRNA), e primers espécies específicos para Candida albicans (Calb), Candida glabrata (Cgla), Candida tropicalis (Ctro), Candida parapsilosis (Cpar), 
Candida krusei (Ckru), Candida lusitaniae (Clus), Candida guilliermondii (Cgui) e Candida dubliniensis (Cdub) (Tabela 3) (CARVALHO et al., 2007).

Tabela 3 - Primers universais e espécies específicos utilizados na PCR multiplex e dimensões dos fragmentos amplificados para Candida spp. Adaptado de CARVALHO et al., 2007

\begin{tabular}{llll}
\hline Espécies & Primers & Sequência (5'-3') & $\begin{array}{l}\text { Tamanho dos fragmentos } \\
\text { amplificados em pares de } \\
\text { base (pb) }\end{array}$ \\
\hline $\begin{array}{l}\text { Leveduras de relevância } \\
\text { clínica }\end{array}$ & UNI1 & GTCAAACTTGGTCATTTA & $950 / 970$ \\
Candida albicans & UNI2 & TTCTTTTCCTCCGCTTATTG & $583 / 446$ \\
Candida glabrata & Calb & AGCTGCCGCCAGAGGTCTAA & $929 / 839$ \\
Candida tropicalis & Cgla & TTGTCTGAGCTCGGAGAGAG & $583 / 507$ \\
Candida parapsilosis & Ctro & GATTTGCTTAATTGCCCCAC & $570 / 370$ \\
Candida krusei & Ckru & GTCAACCGATTATTTAATAG & $590 / 169$ \\
Candida lusitaneae & Clus & TTCGGAGAGCGAACTAGACT & $433 / 329$ \\
Candida guilliermondii & Cgui & TTGGCCTAGAGATAGGTTCGG & $668 / 512$ \\
Candida dubliniensis & Cdub & CTCAAACCCCTAGGGTTTGG & $591 / 217$ \\
\hline
\end{tabular}

Antes da preparação da mistura reacional da PCR multiplex, os isolados clínicos, congelados, foram cultivados em ágar Sabouraud dextrose com cloranfenicol (HiMedia, Mumbai, Índia) à $35^{\circ} \mathrm{C}\left( \pm 2^{\circ} \mathrm{C}\right)$ por 24 a 48 horas, até que ocorresse crescimento adequado. Após crescimento, colônias foram aplicadas em placa de ágar malte (Liofilchem, Roseto degli Abruzzi, Itália) e incubadas à $35^{\circ} \mathrm{C}\left( \pm 2^{\circ} \mathrm{C}\right)$ por 24 horas (CARVALHO et al., 2007).

Para a reação de PCR multiplex, foram utilizados tampão 0,8X [160mM $\left(\mathrm{NH}_{4}\right)_{2} \mathrm{SO}_{4}$, 670mM Tris-HCL (pH 8,8)] (Bioline, Kleve, Alemanha), $\mathrm{MgCl}_{2}$ 3,5mM (Bioline, Kleve, Alemanha), mistura de dNTP [200 $\mu \mathrm{M}$ cada (Invitrogen, Glasgow, Reino Unido)], mistura de primers (UNI1 e UNI2 $0,55 \mu \mathrm{M}$ cada; Cgui $0,05 \mu \mathrm{M}$; Calb e Ckru $0,15 \mu \mathrm{M}$ cada; Cgla, Ctro e

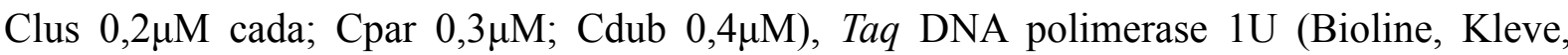
Alemanha) e água bidestilada estéril (Braun, Melsungen, Alemanha). A esta mistura, foi adicionada, com auxílio de aplicador estéril, quantidade mínima da colônia crescida em ágar malte (Liofilchem, Roseto degli Abruzzi, Itália) e o volume final da reação foi $20 \mu \mathrm{L}$ (CARVALHO et al., 2007).

A PCR multiplex foi processada no termociclador Tpersonal® (Whatman Biometra, Goettingen, Alemanha) nas seguintes condições de ciclagem: 10 minutos a $94^{\circ} \mathrm{C}$ para desnaturação do DNA e ativação da enzima, 40 ciclos de 15 segundos a $94^{\circ} \mathrm{C}, 30$ segundos a 
$55^{\circ} \mathrm{C}$, e 45 segundos a $65^{\circ} \mathrm{C}$ para anelamento, extensão e amplificação (CARVALHO et al., 2007).

À cada produto amplificado, foi adicionado tampão de corrida (glicerol $(30 \%(\mathrm{p} / \mathrm{v}))$ e azul bromofenol $(0,25 \%))$, e alíquotas de $10 \mu \mathrm{L}$ de cada produto foram separadas por eletroforese em gel de agarose (Gibco, Bolton, Reino Unido) a 2\% (p/v) em TBE 0,5X (Tris 0,09M, ácido bórico 0,09M e EDTA 20mM, pH 8,3) com GreenSafe Premium ${ }^{\circledR}$ (Nzytech, Lisboa, Portugal) incorporado. A corrida eletroforética ocorreu a 50 volts, durante 60 minutos (CARVALHO et al., 2007).

As bandas formadas foram visualizadas pelo sistema UVIDOC ${ }^{\circledR}$ (Uvitec, Cambridge, Inglaterra) e o marcador de pesos moleculares utilizado foi o GeneRuler 100 bp DNA Ladder Plus [0,5 mg DNA/mL (Fermentas, Burlington, Canada)](CARVALHO et al., 2007).

\subsubsection{Reação em Cadeia da Polimerase associada à Restriction Fragment Length} Polymorphism (PCR RFLP)

Para a técnica PCR Restriction Fragment Length Polymorphism (PCR RFLP) ou Reação em Cadeia da Polimerase associada ao Polimorfismo do Tamanho do Fragmento de Restrição, foi realizado extração de DNA de acordo com Millar e colaboradores (2002) com algumas adaptações. Colônias cultivadas em ágar Sabouraud com cloranfenicol (HiMedia, Mumbai, Índia) a $35^{\circ} \mathrm{C}\left( \pm 2^{\circ} \mathrm{C}\right)$ durante 48 horas foram suspensas em tubo de micro centrifugação $(1,5 \mathrm{~mL})$ contendo $500 \mu \mathrm{L}$ de tampão de lise (Tris $10 \mathrm{mM}$, EDTA $1 \mathrm{mM} \mathrm{pH} 8$, SDS $1 \%, \mathrm{NaCl} 100 \mathrm{mM}$, Triton $\mathrm{X}-1002 \%)$ e $200 \mu \mathrm{L}$ de esferas de vidro $(0,4$ a $0,6 \mathrm{~mm}$ de diâmetro (Sigma-Aldrich, Missouri, EUA). Em seguida, a suspensão foi fortemente agitada durante 3 minutos, colocada em ThermoBlock ${ }^{\circledR}$ (banho-maria seco) (Biosan, Michigan, EUA) a $65^{\circ} \mathrm{C}$ durante 1 hora e, quando retirada do banho-maria seco, foi novamente agitada durante 3 minutos e centrifugada durante 10 minutos a $11000 g$. O sobrenadante foi recuperado para um novo tubo e guardado a temperatura inferior a $20^{\circ} \mathrm{Candida} \mathrm{O} \mathrm{DNA}$ extraído foi diluído (1:750) em tampão TE (Tris $10 \mathrm{mM}$, EDTA $1 \mathrm{mM})$ e alíquotas $(100 \mu \mathrm{L})$ foram conservadas também a $20^{\circ} \mathrm{C}$ negativos.

Após extração de DNA, foi preparado a mistura reacional com volume final de $25 \mu \mathrm{L}$. Para a preparação da mistura foram utilizados: tampão 10X [160mM $\left(\mathrm{NH}_{4}\right)_{2} \mathrm{SO}_{4}, 670 \mathrm{mM}$ 
Tris-HCL (pH 8,8)] (Bioline, Kleve, Alemanha), $\mathrm{MgCl}_{2}$ 3,5mM (Bioline, Kleve, Alemanha), mistura de dNTP $200 \mu \mathrm{M}$ cada (Invitrogen, Glasgow, Reino Unido), mistura de primers (ITS1 5'TCCGTAGAACGTGCG3’ e ITS4 (5'TCGTCGGCTTATTGATATGC3', 0,2 $\mu \mathrm{M}$ cada), Taq DNA polimerase 1U (Bioline, Kleve, Alemanha), água bidestilada estéril (Braun, Melsungen, Alemanha) e $5 \mu \mathrm{L}$ de DNA (diluição 1:750) (MIRHENDI et al., 2006).

A mistura reacional foi submetida à temperatura de $94^{\circ} \mathrm{C}$ durante 5 minutos no termociclador Tpersonal ${ }^{\circledR}$ (Whatman Biometra, Goettingen, Alemanha), seguida por 25 ciclos de $94^{\circ} \mathrm{C}$ por 30 segundos, $56^{\circ} \mathrm{C}$ por 45 segundos e $72^{\circ} \mathrm{C}$ durante 1 minuto. A extensão final ocorre a $72{ }^{\circ} \mathrm{C}$ durante 7 minutos (MIRHENDI et al., 2006).

Os produtos amplificados foram submetidos à eletroforese em gel de agarose (Gibco, Bolton, Reino Unido) a 1,5\% (p/v) em TBE 0,5X (Tris 0,09M, ácido bórico 0,09M e EDTA 20mM, pH 8,3) e corado com GreenSafe Premium ${ }^{\circledR}$ (Nzytech, Lisboa, Portugal). Foi aplicado no gel $8 \mu \mathrm{L}$ de produto amplificado com tampão de corrida (glicerol $(30 \%(\mathrm{p} / \mathrm{v}))$ e azul bromofenol (0,25\%)), e $6 \mu \mathrm{L}$ de marcador molecular GeneRuler 100 bp DNA Ladder Plus [0,5 mg DNA/mL (Fermentas, Burlington, Canada)]. A eletroforese foi realizada durante 30 minutos a 100 volts em tampão TBE 0,5X (Tris 0,09M, ácido bórico 0,09M e EDTA 20mM, $\mathrm{pH} 8,3$ ), os géis foram visualizados sob luz UV e as imagens captadas e registadas pelo sistema UVIDOC ${ }^{\circledR}$ (Uvitec, Cambridge, Inglaterra) (MIRHENDI et al., 2006).

Para a restrição dos fragmentos de DNA, obtidos na reação anterior, foram utilizados $2 \mu \mathrm{L}$ de tampão RE 10 x (Promega, Wisconsin, EUA); $0,2 \mu \mathrm{L}$ de tampão BSA acetilado 10 $\mu \mathrm{g} /$ $\mu \mathrm{L}$ (New England Biolab, Hitchin, Reino Unido); 0,5 $\mu \mathrm{L}$ de enzima MspI $10 \mu \mathrm{g} / \mu \mathrm{L}$ (Promega, Wisconsin, EUA) e 16,3 $\mu \mathrm{L}$ de água destilada (Braun, Melsungen, Alemanha). A esta mistura, adicionou-se $1 \mu \mathrm{L}$ do produto de amplificação da região ITS do rDNA de cada amostra, perfazendo um volume final de $20 \mu \mathrm{L}$. Os tubos foram incubados a $37^{\circ} \mathrm{C}$ durante 2 horas e, após período de incubação, os produtos foram observados em eletroforese de gel de agarose (Gibco, Bolton, Reino Unido) a 2,0\% Depois da corrida eletroforética a 50 volts durante 90 minutos, foram visualizados sob luz UV. As imagens foram captadas e registadas pelo sistema UVIDOC® (Uvitec, Cambridge, Inglaterra). As dimensões dos fragmentos esperados para as diferentes espécies de Candida está representada na Tabela 4 (MIRHENDI et al., 2006). 
Tabela 4 - Dimensões dos fragmentos amplificados para Candida spp. após PCR RFLP e restrição com MspI. Adaptado de MIRHENDI et al., 2006

\begin{tabular}{lll}
\hline Espécie & Região ITS $(\mathbf{p b})$ & Produto de Restrição $(\mathbf{p b})$ \\
\hline Candida albicans & 535 & $297 / 238$ \\
Candida glabrata & 871 & $557 / 314$ \\
Candida guilliermondii & 608 & $371 / 155 / 82$ \\
Candida krusei & 510 & $261 / 249$ \\
Candida tropicalis & 524 & $340 / 184$ \\
Candida parapsilosis & 520 & 520 \\
\hline
\end{tabular}

3.1.5.3 Espectrometria de massas (MS) e Matrix Assisted Laser Desorption Ionization Time-of-flight (MALDI-TOF)

Colônias cultivadas em ágar Sabouraud com cloranfenicol (HiMedia, Mumbai, Índia) a $35^{\circ} \mathrm{C}\left( \pm 2^{\circ} \mathrm{C}\right)$ durante 48 horas foram utilizadas na realização da técnica de espectrometria de massa MALDI-TOF. Quantidade mínima das colônias de Candida spp. foram aplicadas nos splots dos slides alvos (Biomérieux, Marcy I'Etoile, França) e, após secagem à temperatura ambiente foi adicionado $0,5 \mu \mathrm{L}$ de ácido fórmico 25\% (v/v) (Biomérieux, Marcy I'Etoile, França). Novamente, o material aplicado sobre o slide foi mantido à temperatura ambiente para secagem e sobre a camada formada entre a colônia de Candida spp e o ácido fórmico foi aplicado $1 \mu \mathrm{L}$ de solução de matriz 3,1\% (ácido alfa-ciano-4-hidroxicinâmico - CHCA, Biomérieux, Marcy I'Etoile, França). Após secagem da matrix, também à temperatura ambiente, o slide foi transferido para a estação da leitura, onde a identificação microbiana foi alcançada por meio da obtenção de espectros. Estes espectros foram analisados utilizando banco de dados de referência, onde são feitas comparações dos picos formados com os padrões característicos da espécie, gênero ou família do microrganismo, resultando na identificação do organismo. Foram considerados resultados válidos quando o percentual de probabilidade de identificação foi igual ou maior a $85 \%$. Como controle positivo foi utilizado cepa de referência de Escherichia coli ATCC 8739 (KIM et al., 2014).

\subsection{Determinação do perfil de susceptibilidade dos isolados clínicos}

O perfil de susceptibilidade dos isolados clínicos de Candida spp. foi realizado pelo método de disco difusão de acordo com o documento M44-A do Clinical and Laboratory Standards Institute (CLSI) dos Estados Unidos da América (CLSI, 2004). 


\subsubsection{Agentes antifúngicos}

Foram utilizados discos de voriconazol $1 \mu \mathrm{g}$ (Bio-Rad, Marnes-la-Coquette, França),

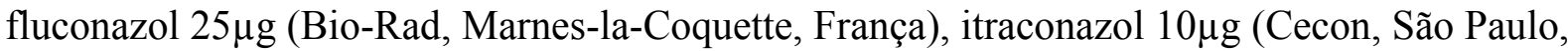
SP, Brasil), 5-fluorocitosina $1 \mu \mathrm{g}$ (Bio-Rad, Marnes-la-Coquette, França), e anfotericina B $100 \mu \mathrm{g}$ (Bio-Rad, Marnes-la-Coquette, França). Todos os discos são comerciais e foram adquiridos estéreis e conservados a temperatura de 2 e $8^{\circ} \mathrm{C}$ (CLSI, 2004).

\subsubsection{Preparo do inóculo fúngico}

A partir de subcultivos dos isolados clínicos, em ágar Sabouraud dextrose com cloranfenicol (HiMedia, Mumbai, Índia) à $35^{\circ} \mathrm{C}\left( \pm 2^{\circ} \mathrm{C}\right)$ por 24 a 48 horas, foram preparados inóculos fúngicos. Para isto, foram suspensas colônias em $5,0 \mathrm{~mL}$ de solução salina estéril $0,85 \%$, contidas em tubos de ensaios, até obter uma suspensão equivalente a 0,5 da escala de McFarland ( 1 x $10^{6}$ a 5 x $10^{6}$ células/mL) (CLSI, 2004).

Além dos isolados clínicos, foram utilizados, como controle, cepas padrões de Candida parapsilosis (ATCC 22019) e Candida albicans (ATCC 90028).

\subsubsection{Execução do método de disco difusão}

Para o método de disco difusão foi utilizado o ágar Mueller-Hinton (HiMedia, Mumbai, Índia) com $2 \%$ de glicose e $0,5 \mu \mathrm{g} / \mathrm{mL}$ de azul de metileno, no qual foi inoculado, com swab, o inóculo fúngico, através da técnica de esgotamento em estria com rotação da placa em ângulo de $60^{\circ}$ por três vezes. Após a inoculação, foram aplicados os discos com os antifúngicos sobre o meio e as placas foram incubadas a $35^{\circ} \mathrm{C}\left( \pm 2^{\circ} \mathrm{C}\right)$ por até 48 horas (CLSI, 2004).

\subsubsection{Leitura e interpretação dos resultados}

A leitura dos resultados foi realizada utilizando paquímetro para medir os diâmetros dos halos de inibição do crescimento em milímetros ( $\mathrm{mm})$, observados em volta dos discos 
com os antifúngicos. Diante os valores obtidos, as espécies de Candida foram categorizadas em Resistente (R), Sensível Dose Dependente (SDD) e Sensível (S) (Tabela 5).

Tabela 5 - Padrões interpretativos dos diâmetros dos halos de inibição e CIM dos agentes antifúngicos

\begin{tabular}{llcccccc}
\hline \multirow{2}{*}{ Agentes antifúngicos } & \multirow{2}{*}{ Carga } & \multicolumn{3}{c}{ Diâmetros $(\mathbf{m m})$} & \multicolumn{3}{c}{ CIM $(\boldsymbol{\mu g} / \mathbf{m L})$} \\
\cline { 2 - 7 } & & $\mathbf{R}$ & SDD & S & R & SDD & S \\
\hline Voriconazol $^{\mathrm{a}}$ & $1 \mu \mathrm{g}$ & $\leqq 13$ & $14-16$ & $\geqq 17$ & $\geqq 4$ & 2 & $\leqq 1$ \\
Fluconazol $^{\mathrm{a}}$ & $25 \mu \mathrm{g}$ & $\leqq 14$ & $15-18$ & $\geqq 19$ & $\geqq 64$ & $16-32$ & $\leqq 8$ \\
Itraconazol $^{\mathrm{b}}$ & $10 \mu \mathrm{g}$ & $\leqq 11$ & $19-12$ & $\geqq 20$ & - & - & - \\
5-Fluorocitosina $^{\mathrm{b}}$ & $1 \mu \mathrm{g}$ & $<10$ & $20-10$ & $>20$ & $>25$ & $1.56-25$ & $<1.56$ \\
Anfotericina $^{\mathrm{b}}$ & $100 \mu \mathrm{g}$ & $\leqq 10^{\mathrm{c}}$ & - & $\geqq 20$ & $\geqq 1^{\mathrm{c}}$ & - & $<1$ \\
\hline
\end{tabular}

a - Valores de acordo com o documento M44-S2 do CLSI (CLSI, 2007). b - Valores de acordo com as bulas dos fabricantes. c - Valores correspondentes a categoria SDD ou R.

Segundo a CLSI (2004), são considerados "Resistentes", os micro-organismos que não são inibidos pela concentração normalmente alcançada pelo agente antifúngico com doses normais padronizadas ou quando a eficácia clínica não tem sido comprovada em estudos, "Sensível Dose Dependente" - os micro-organismos que se encontram numa faixa de susceptibilidade em que a Concentração Inibitória Mínima (CIM) aproxima-se ou excede o nível que o agente antifúngico atinge e "Sensível", os micro-organismos que podem ser apropriadamente tratados com a dose recomendada do agente antifúngico.

\subsection{Avaliação da atividade antifúngica de extratos brutos vegetais}

\subsubsection{Material botânico}

Partes das plantas de Eugenia dysenterica DC (Hexachlamys macedoi Legrand), Pouteria ramiflora (Mart.) Radlk, Pouteria torta (Mart.) Radlk, Bauhinia rufa (Bong.) Steud, Erythroxylum subrotundum A. St.-Hil e Erythroxylum daphnites Mart. foram coletadas na região do Cerrado e entorno de Brasília, identificadas e depositadas pelos professores Christopher William Fagg e Suelí Maria Gomes, em exsicata, no Herbário da Universidade de Brasília (UnB) (Table 6). 
Tabela 6 - Espécies de plantas utilizadas, família botânica e voucher

\begin{tabular}{lll}
\hline Espécies de plantas & Família & Voucher \\
\hline Eugenia dysenterica DC (Hexachlamys macedoi Legrand) & Myrtaceae & $914(\mathrm{UnB})$ \\
Pouteria ramiflora (Mart.)Radlk & Sapotaceae & $3671(\mathrm{UnB})$ \\
Pouteria torta (Mart.)Radlk & Sapotaceae & $3674(\mathrm{UnB})$ \\
Bauhinia rufa (Bong.) Steud & Fabaceae & $32144(\mathrm{UnB})$ \\
Erythroxylum subrotundum A. St.-Hil & Erythroxylaceae & $2194(\mathrm{UnB})$ \\
Erythroxylum daphnites Mart & Erythroxylaceae & $2193(\mathrm{UnB})$ \\
\hline
\end{tabular}

\subsubsection{Extração botânica}

Para a obtenção dos extratos, folhas foram secadas à temperatura ambiente e pulverizadas em moinho de facas. Os extratos etanólicos e hexânicos foram obtidos por maceração, por três vezes, durante sete dias cada um. Primeiro, o material botânico pulverizado $(40 \mathrm{~g})$ foi embebido no hexano $(2 \mathrm{~L})$ e macerado, à temperatura ambiente. A remoção dos solventes foi realizada em pressão reduzida à temperatura inferior a $40^{\circ} \mathrm{C}$. Com o material resultante, o mesmo procedimento foi realizado, utilizando etanol a 95\% (SOUZA et al., 2012). Os extratos aquosos foram obtidos por infusão, utilizando $400 \mathrm{~g}$ do material botânico e água destilada (3L). Após filtração, a água foi removida por liofilização (SOUZA et al., 2012). Todos os extratos utilizados neste ensaio fazem parte da coleção de extratos do Grupo de Pesquisa, Desenvolvimento, Produção e Controle da Qualidade de Medicamentos e foram produzidos pelo Laboratório de Produtos Naturais da Universidade de Brasília (UnB) (Tabela 7).

Tabela 7 - Plantas utilizadas, partes da planta, solventes e extratos brutos vegetais

\begin{tabular}{llll}
\hline Espécies de plantas & Parte & Solventes & Extratos brutos \\
\hline Eugenia dysenterica DC (Hexachlamys macedoi Legrand) & Folhas & Água & A \\
Pouteria ramiflora (Mart.)Radlk & Folhas & Água, Etanol & A, E \\
Pouteria torta (Mart.)Radlk & Folhas & Etanol & E \\
Bauhinia rufa (Bong.) Steud & Folhas & Água, Etanol & A, E \\
Erythroxylum subrotundum A. St.-Hil & Folhas & Água, Etanol & A, E \\
Erythroxylum daphnites Mart & Folhas & Água, Etanol & A, E \\
\hline
\end{tabular}

A - Extrato aquoso, E - extrato etanólico 


\subsubsection{Preparação dos discos}

Na preparação dos discos, 100mg dos extratos etanólico, aquoso e hexânico foram solubilizados com $1 \mathrm{~mL}$ dos solventes específicos (etanol 95\%, água destilada estéril e hexano), obtendo soluções estoques com concentração de $100 \mathrm{mg} / \mathrm{mL}$. Em seguida, $10 \mu \mathrm{L}$ da solução estoque foi adicionada em discos de papel de filtro de $6 \mathrm{~mm}$ de diâmetro, que foram submetidos à temperatura ambiente, durante 24 horas, para secagem. A concentração final do extrato por disco foi de $1000 \mu \mathrm{g}$. Também foram preparados discos com os solventes, etanol 95\%, água destilada estéril e hexano, que foram utilizados como controle negativo (RAZMAVAR et al., 2014).

\subsubsection{Preparo do inóculo fúngico}

A partir de subcultivos dos isolados clínicos de Candida spp., em ágar Sabouraud dextrose com cloranfenicol (HiMedia, Mumbai, Índia) à $35^{\circ} \mathrm{C}\left( \pm 2^{\circ} \mathrm{C}\right)$ por 24 a 48 horas, foram preparados inóculos fúngicos. Para isto, foram suspensas colônias em 5,0mL de solução salina estéril $0,85 \%$, contidas em tubos de ensaios, até obter uma suspensão equivalente a 0,5 da escala de McFarland (1 x 106 a 5 x 106 células/mL) (CLSI, 2004).

\subsubsection{Execução do método de disco difusão}

Para o método de disco difusão foi utilizado o ágar Mueller-Hinton (HiMedia, Mumbai, Índia) com $2 \%$ de glicose e azul de metileno $(0,5 \mu \mathrm{g} / \mathrm{mL})$, no qual foi inoculado, com swab, o inóculo fúngico, através da técnica de esgotamento em estria com rotação da placa em ângulo de $60^{\circ}$ por três vezes. Após a inoculação, foram aplicados os discos, com os extratos impregnados, sobre o meio e as placas foram incubadas a $35^{\circ} \mathrm{C}\left( \pm 2^{\circ} \mathrm{C}\right)$ por até 48 horas (CLSI, 2004). Foram utilizados como controle positivo disco de Fluconazol 25 $\mu \mathrm{g}$ (BioRad, Marnes-la-Coquette, França) e, como controles negativos, discos de papel com etanol 95\%, água destilada e hexano. Todos os extratos e controles foram testados em triplicata e calculado a média dos diâmetros dos halos de inibição (RAZMAVAR et al., 2014). 


\subsubsection{Concentração Inibitória Mínima (CIM)}

A avaliação da CIM, também foi realizada pelo método disco difusão e foram utilizadas diluições seriadas com a solução estoque dos extratos $(1 / 2 ; 1 / 4 ; 1 / 8 ; 1 / 32 ; 1 / 64$; 1/128). Em seguida, $10 \mu \mathrm{L}$ de cada diluição foi impregnada em discos de papel de filtro $(6 \mathrm{~mm})$ que foram submetidos à temperatura ambiente, por 24 horas, para secagem. A concentração final dos extratos por disco foi de $500 \mu \mathrm{g}$ a $7,8 \mu \mathrm{g}$. O inóculo fúngico foi semeado na superfície do agar Mueller Hinton com 2,0\% de glicose e de azul de metileno $(0,5 \mu \mathrm{g} / \mathrm{mL})$ pelo mesmo método descrito acima e os discos foram depositados no meio de cultura semeado com o inóculo fúngico. As placas foram incubadas a $35^{\circ} \mathrm{C}\left( \pm 2^{\circ} \mathrm{C}\right)$ por 24 a 48 horas. Discos com os solventes foram utilizados como controle negativos e todos os extratos e controles foram testados em triplicata e calculado a média dos diâmetros dos halos de inibição (CLSI, 2004; RAZMAVAR et al., 2014). A determinação da CIM dos extratos brutos vegetais foi realizada apenas com as cepas padrão ATCC de Candida spp. A CIM foi definida como a menor concentração que impede o crescimento de microrganismos (CLSI, 2004).

\subsubsection{Leitura e interpretação dos resultados}

A leitura dos resultados foi realizada medindo com paquímetro os diâmetros dos halos de inibição do crescimento observadas em volta dos discos. Para este estudo, foram considerados extratos com atividade inibitória aqueles que apresentaram diâmetro de inibição $\geq 10 \mathrm{~mm}$ e os extratos sem atividade inibitória aqueles que apresentaram diâmetro $<10 \mathrm{~mm}$. 


\section{RESULTADOS E DISCUSSÃO}

\subsection{Identificação dos isolados clínicos por métodos clássicos}

$\mathrm{Na}$ identificação macroscópica, todos os isolados clínicos $(\mathrm{n}=150)$ apresentaram morfologia característica de fungos leveduriformes em ágar Sabouraud dextrose com cloranfenicol após 48 horas de incubação a $35^{\circ} \mathrm{C}\left( \pm 2^{\circ} \mathrm{C}\right)$, aspecto cremoso ou seco, liso ou enrugado, brilhoso ou pálido e coloração branca a creme. Quando analisados microscopicamente, com lactofenol azul de algodão, apresentaram formato oval, com ou sem brotamento (Figura 2).
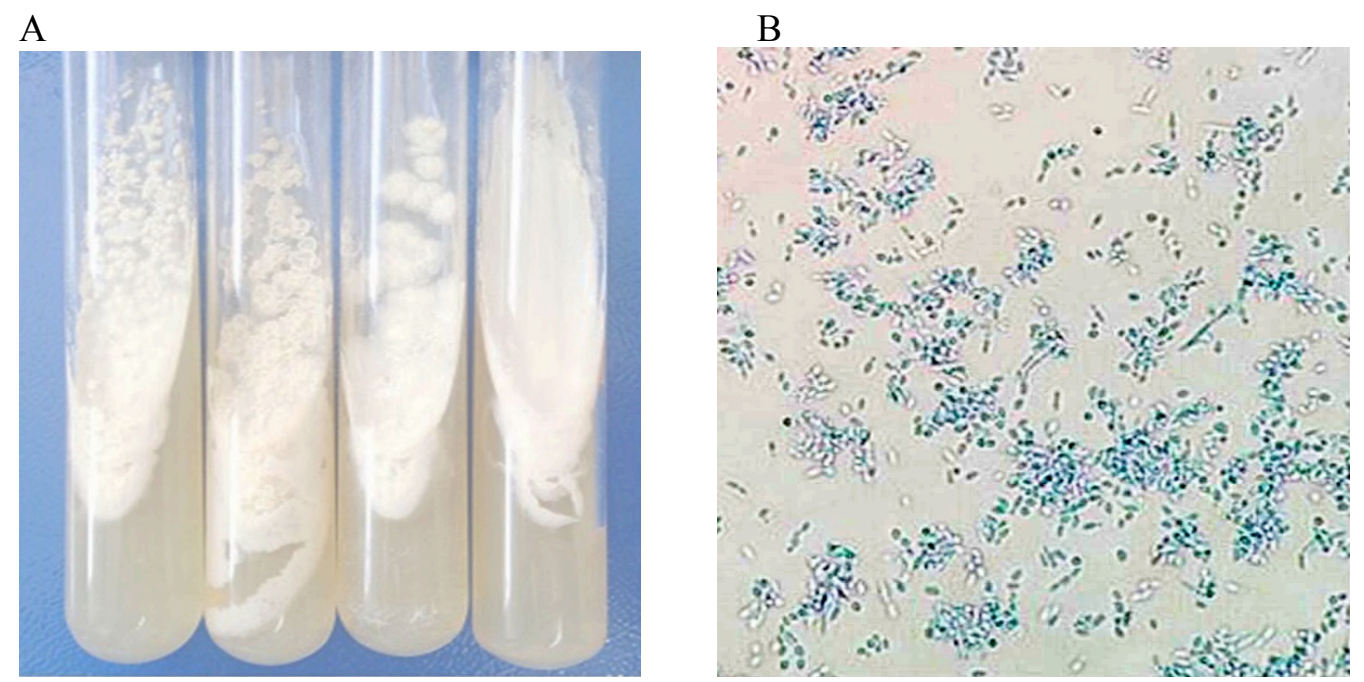

Figura 2 - Características macroscópicas e microscópicas dos isolados clínicos

(A) Característica macroscópica: colônias após 48 horas de incubação a $25^{\circ} \mathrm{C}\left( \pm 2{ }^{\circ} \mathrm{C}\right)$ em ágar Sabouraud dextrose com cloranfenicol. (B) Característica microscópica: estruturas leveduriformes em lactofenol azul de algodão (400X)

Na Prova do Tubo Germinativo (PTG), 51,3\% ( $\mathrm{n}=77)$ dos isolados produziram tubo germinativo $(\mathrm{PTG}+)$ e foram identificadas como Candida albicans e 48,7\% (n=73) não produziram tubo germinativo (PTG-) e foram identificados como Candida não albicans. A cepa de referência, Candida albicans ATCC 90028, apresentou resultado positivo, ratificando a execução e condições da prova (Figura 3). 
A

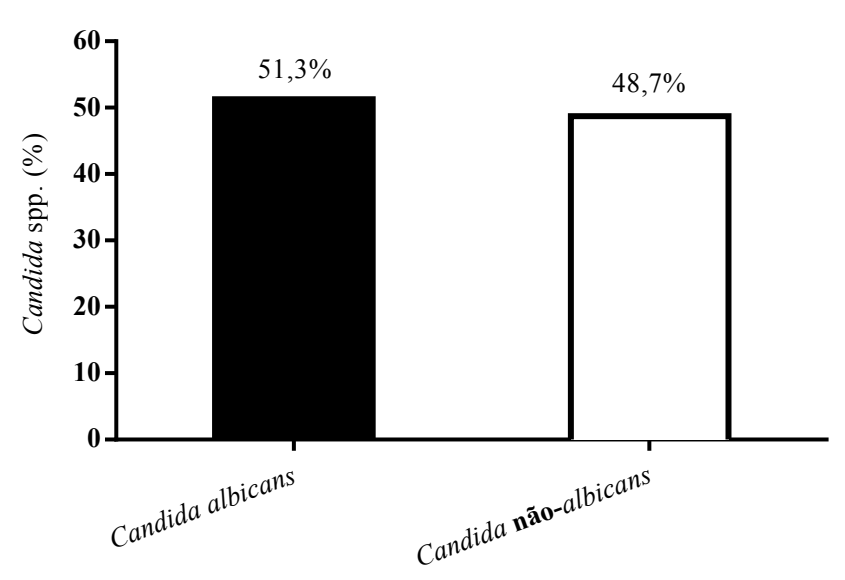

B

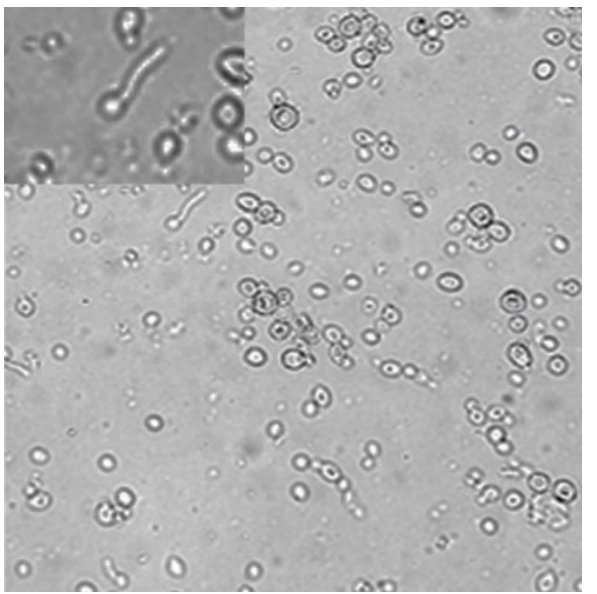

Figura 3 - Resultados da prova do tubo germinativo (PTG)

(A) Distribuição dos isolados clínicos. (B) Controle positivo - Candida albicans ATCC 90028, formação do tubo germinativo

$\mathrm{Na}$ identificação presuntiva com o meio cromogênico, os isolados que apresentaram colônias em tons de verde foram identificados como Candida albicans $(50 \% ; n=75)$, os que demonstraram colônias de tons azul a cinza, foram identificadas como Candida tropicalis $(14,7 \% ; n=22)$ e aqueles que formaram colônias de tons rosa foram identificadas como Candida krusei $(1,3 \% ; \mathrm{n}=2)$. Também foram detectados, isolados mistos $(1,3 \% ; \mathrm{n}=2)$ com duas colônias de cores diferentes [verde + malva (Candida albicans + Candida não albicans) e verde + cinza (Candida albicans + Candida tropicalis) $]$ e os demais isolados, $32,7 \%(\mathrm{n}=49)$, não apresentaram colônias de colorações específicas e foram agrupadas como Candida spp. As cepas de referências, Candida albicans ATCC 90028, Candida tropicalis ATCC 28707 e Candida krusei ATCC 34135, utilizadas como controle, apresentaram cores equivalentes aos padrões pré estabelecidos pelo fabricante (Figura 4). 


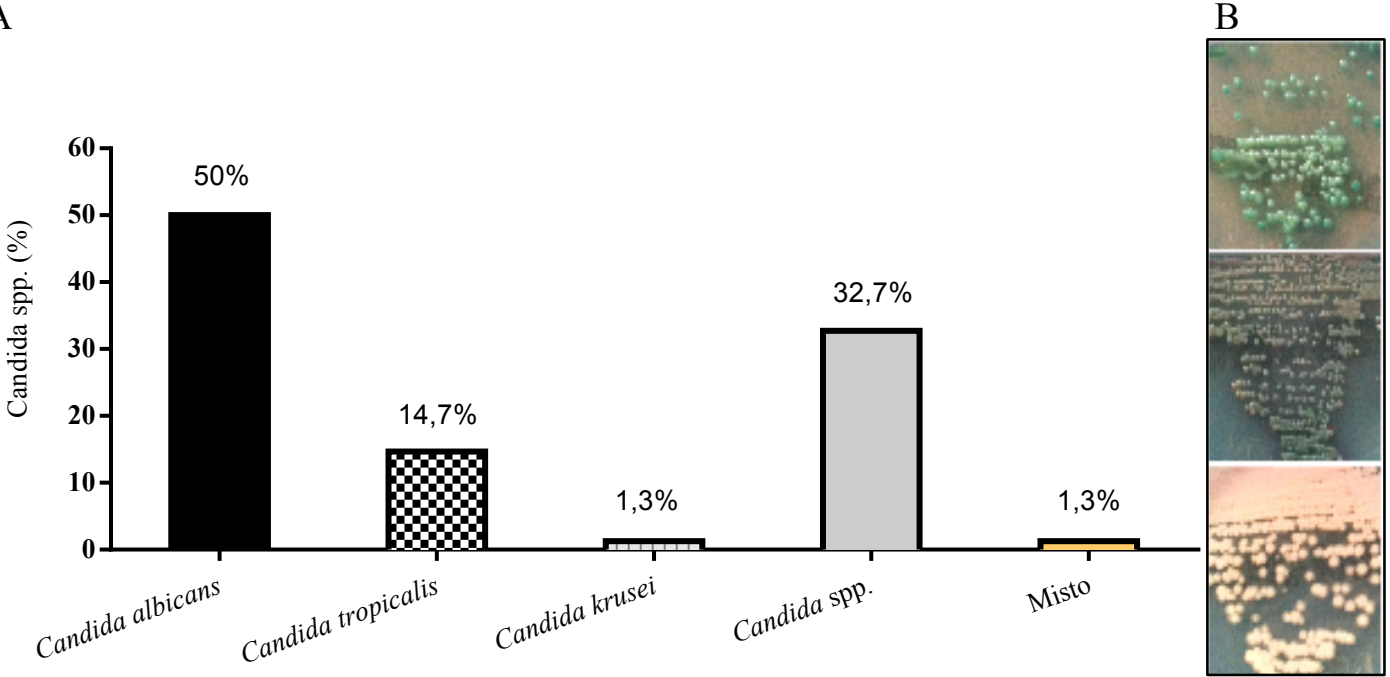

Figura 4 - Resultados da identificação presuntiva em meio cromogênico

(A) Distribuição dos isolados clínicos (B) Controle Positivo - Candida albicans ATCC 90028, Candida tropicalis ATCC 28707 e Candida krusei ATCC 34135

$\mathrm{Na}$ identificação bioquímica, todos os isolados apresentaram percentual de probabilidade de acerto igual ou superior a $85 \%$. As espécies identificadas foram: Candida albicans 50\% (n=75), Candida tropicalis 15,3\% (n=23), Candida krusei 1,3\% (n=2), Candida parapsilosis 18,7\% (n=28), Candida glabrata 9,3\% (n=14), Candida guilliermondii 0,7\% $(\mathrm{n}=1)$ e Candida famata 4,7\% (n=7). A cepa de referência, Candida albicans ATCC 90028 foi identificada com 99,9\% de probabilidade de acerto (Figura 5).

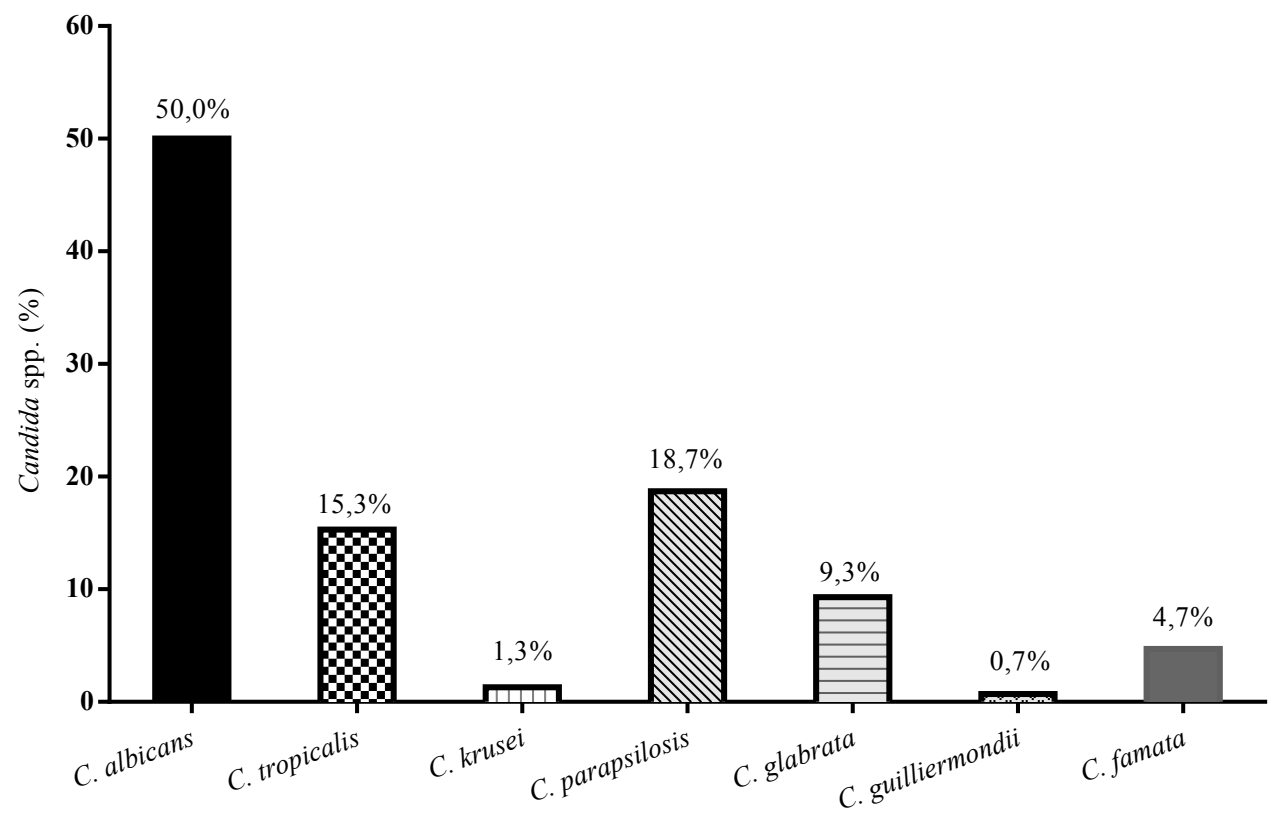

Figura 5 - Resultados da identificação bioquímica por reações enzimáticas e colorimétricas 
A análise final da identificação fenotípica foi realizada, comparando os resultados obtidos nos três métodos, prova do tubo germinativo, meio cromogênico e provas bioquímicas, que podem ser vistos na Tabela 8 .

Tabela 8 - Comparação das metodologias de identificação fenotípica utilizadas no estudo

\begin{tabular}{llll}
\hline \multicolumn{2}{l}{ Metodologias de identificação } & \\
\hline Espécies de Candida & Tubo germinativo (PTG) Meio cromogênico & $\begin{array}{l}\text { Provas } \\
\text { bioquímicas }\end{array}$ \\
\hline Candida albicans & $51,3 \%$ & $50,0 \%$ & $50,0 \%$ \\
\hline Candida spp. / Candida não albicans & $48,7 \%$ & $32,7 \%$ & - \\
\hline Candida tropicalis & - & $14,7 \%$ & $15,3 \%$ \\
\hline Candida krusei & - & $1,3 \%$ & $1,3 \%$ \\
\hline Mista & & $1,3 \%$ & - \\
\hline Candida parapsilosis & - & - & $18,7 \%$ \\
\hline Candida glabrata & - & - & $9,3 \%$ \\
\hline Candida guilliermondii & - & - & $0,7 \%$ \\
\hline Candida famata & - & - & $4,7 \%$ \\
\hline
\end{tabular}

$\mathrm{Na}$ comparação dos resultados, apenas dois isolados clínicos (1,3\%) apresentaram discordância. Estes isolados, apontados como Candida albicans na prova do tubo germinativo, foram identificados como isolados mistos pelo CHROMagar Candida ${ }^{\circledR}$ e caracterizados como Candida tropicalis e Candida glabrata pelo sistema MicroScan WalkAway ${ }^{\circledR}$ (Figura 6). Como não houve concordância entre os métodos, estes dois isolados foram reclassificados como Candida spp (Figura 6).

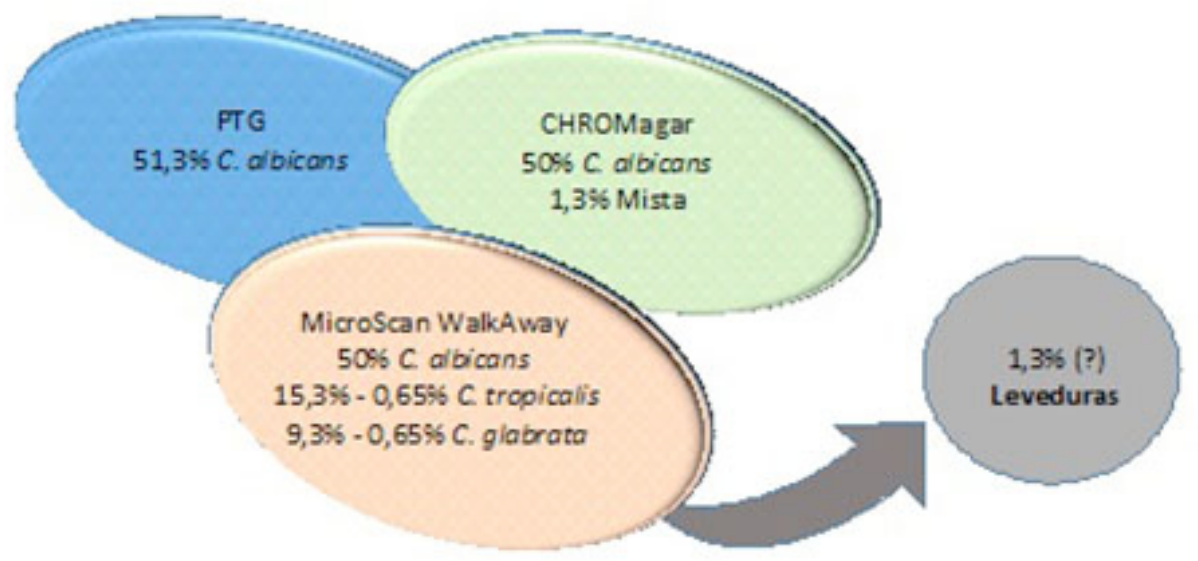

Figura 6 - Resultados divergentes nas metodologias empregadas na caracterização fenotípica de isolados clínicos 
As explicações para tais discordâncias podem estar relacionadas às limitações apresentadas por estes métodos ou a características inerentes às leveduras. A prova do tubo germinativo, embora rápida e de fácil execução, depende de expertise técnica para sua realização e nem sempre apresenta $100 \%$ de acurácia, pois isolados de Candida tropicalis, Candida parapsilosis e outras leveduras como Cryptococcus gastricus também podem formar tubo germinativo, apresentando resultado falso positivo (CAMPBELL et al., 1998; FREYDIERE; GUINET, 1997; LIPPERHEIDE et al., 1993; PERRY et al., 1990). Assim como cerca de $5 \%$ dos isolados de Candida albicans não produzem tubo germinativo (LIPPERHEIDE et al., 1993) e podem apresentar resultados falso negativos.

Uma das vantagens do meio cromogênico é a caracterização de duas ou mais espécies de Candida na mesma placa de isolamento. No entanto, a taxa de desenvolvimento da cor característica de espécies de Candida pode sofrer influência da temperatura de incubação. Por exemplo, Candida albicans, a $37^{\circ} \mathrm{C}$ durante 48 horas de incubação, apresenta colônias esverdeadas e, se alterarmos a faixa de temperatura para o intervalo de 25 a $30^{\circ} \mathrm{C}$, apresentará coloração rosa. Além disso, falta consenso para a identificação de outras espécies de Candida, diferentes de Candida albicans, Candida krusei e Candida tropicalis, que são identificadas por este método (CÁRDENES et al., 2002; PINCUS; ORENGA;CHATELLER, 2007; ESTRADA-BARRAZA et al., 2011).

Alguns autores também relatam, que Candida tropicalis representa a principal fonte de falsa identificação para este meio de cultura, devido a sua ampla faixa de variação de cores (CÁRDENES et al., 2002; ESTRADA-BARRAZA et al., 2011).

Com relação as provas bioquímicas enzimáticas e colorimétricas relatos apontam identificações errôneas relacionadas ao crescimento lento ou ao metabolismo das leveduras (ST.GERMAIN; BEAUCHESNE, 1991). Os erros de identificação mais comuns tem ocorrido entre espécies de Candida tropicalis, Candida albicans, Candida krusei e Candida parapsilosis, assim como ocorre com leveduras pouco frequentes, como Wickerhamomyces anomalus (Pichia), Candida kefyr, Cryptococcus unigutulatus, entre outras. Contudo, resultados errôneos apontam a necessidade de confirmar com outras provas complementares (FERRARA et al., 2014). 


\subsection{Identificação dos isolados clínicos por métodos moleculares}

A fim de confirmar a caracterização fenotípica das espécies de Candida, foi realizada a identificação molecular por PCR multiplex. Os resultados obtidos por este método foram analisado por meio da visualização do padrão eletroforético, definido por dois fragmentos amplificados. A amplificação dos dois fragmentos permitiu a diferenciação das espécies de Candida (Figura 7). O aparecimento de apenas um fragmento amplificado, indicou presença de fungo, porém a espécie a qual pertencia este fungo não pode ser identificado e a não amplificação dos fragmentos foi sugestivo de falha na reação. Neste caso, a reação foi repetida.

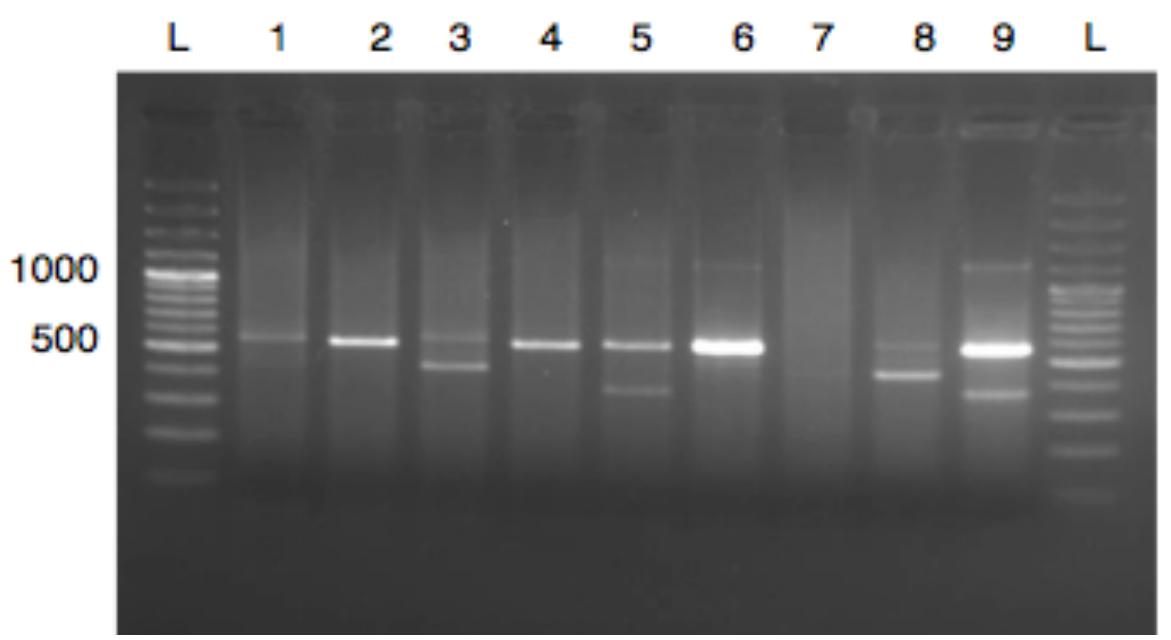

Figura 7 - Gel de agarose mostrando os resultados obtidos por PCR multiplex

Linhas: L - marcador DNA Ladder Plus 100 pb; 1 - Candida albicans; 2 - espécie não identificada; 3 - Candida albicans; 4 - espécie não identificada; 5 - Candida parapsilosis; 6 - espécie não identificada; 7 - falha na reação; 8 - Candida albicans e 9 - Candida parapsilosis

Ainda nesta metodologia, os isolados foram identificados como: Candida albicans 50,7\% (n=76), Candida tropicalis 15,3\% ( $\mathrm{n}=23)$, Candida krusei 0,7\% ( $\mathrm{n}=1)$, Candida parapsilosis 16,6\% (n=25), Candida glabrata $8 \%(\mathrm{n}=12)$ e Candida guilliermondii $0,7 \%$ $(\mathrm{n}=1)$. Também foi detectado um $(0,7 \%)$ isolado misto [Candida albicans + Candida glabrata $(n=1)]$ e $7,3 \%(n=11)$ dos isolados não foram identificados (Figura 8). 


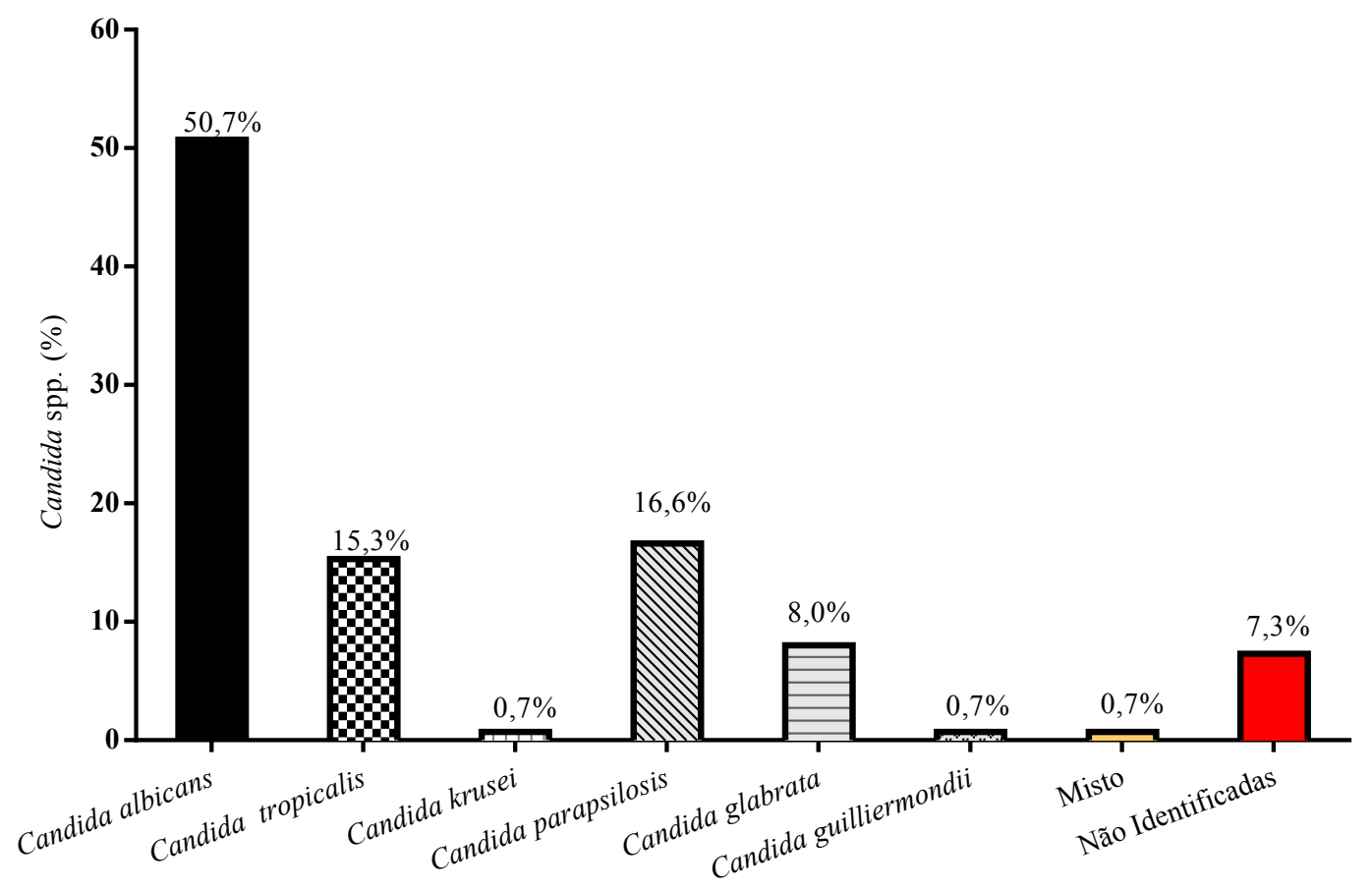

Figura 8 - Resultados da identificação dos isolados clínicos por PCR multiplex

A partir da identificação molecular por PCR multiplex foi possível confirmar 131 (87,3\%) isolados clínicos caracterizados fenotipicamente e os demais isolados $(12,7 \%, \mathrm{n}=19)$ apresentaram resultados discrepantes. Tendo em vista que, foi utilizada quantidade mínima de colônia leveduriforme na realização da PCR multiplex e que não houve controle da concentração do material genético, o que poderia acarretar inibição ou não amplificação do DNA, os isolados discrepantes, que representam três experimentos independentes, foram selecionados e submetidos a outra identificação molecular, empregando a metodologia PCR RFLP, que utiliza DNA extraído.

Na identificação por PCR RFLP, os resultados também foram analisados com base no padrão eletroforético obtido após digestão com a enzima MspI. A princípio, antes da digestão enzimática, foi constatado à amplificação da região ITS,que foi bem-sucedida para todos os isolados analisados. Os fragmentos amplificados, referentes à região ITS, demostraram tamanhos diferentes, que variaram aproximadamente em 400 a 800 pares de base (Figura 9). 


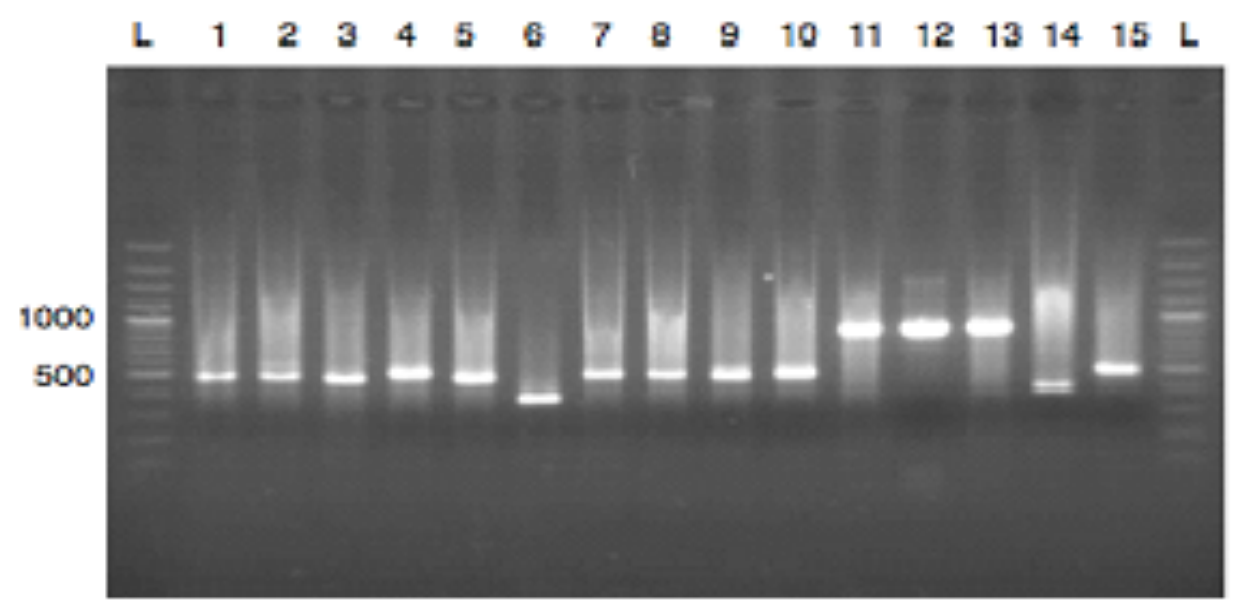

Figura 9 - Gel de agarose mostrando a amplificação da região ITS por PCR RFLP

Linhas: L - marcador DNA Ladder Plus 100 pb; 11, 12, 13 - fragmentos amplificados com 800 pb; 1, 2, 3, 4, 5, 7, $8,9,10,15$ - fragmentos amplificados com $500 \mathrm{pb}$ e 6 e 14 - fragmentos amplificados com $400 \mathrm{pb}$.

Após digestão enzimática, os 19 isolados discrepantes foram identificados como: Candida guilliermondii $(\mathrm{n}=1)$, que produziu perfil de restrição com três sítios, Candida albicans $(\mathrm{n}=3)$, Candida tropicalis $(\mathrm{n}=4)$ e Candida intermedia $(\mathrm{n}=1)$ que apresentaram dois sítios de restrição e Candida parapsilosis $(\mathrm{n}=8)$ que demonstrou apenas um sítio de restrição. Também foram detectados 1 isolado misto de Candida albicans + Candida glabrata com quatro sítios de restrição e 1 isolado demonstrou um sítio de restrição, com aproximadamente $400 \mathrm{pb}$, que foi classificado como levedura pertencente a outro gênero (Figura 10).

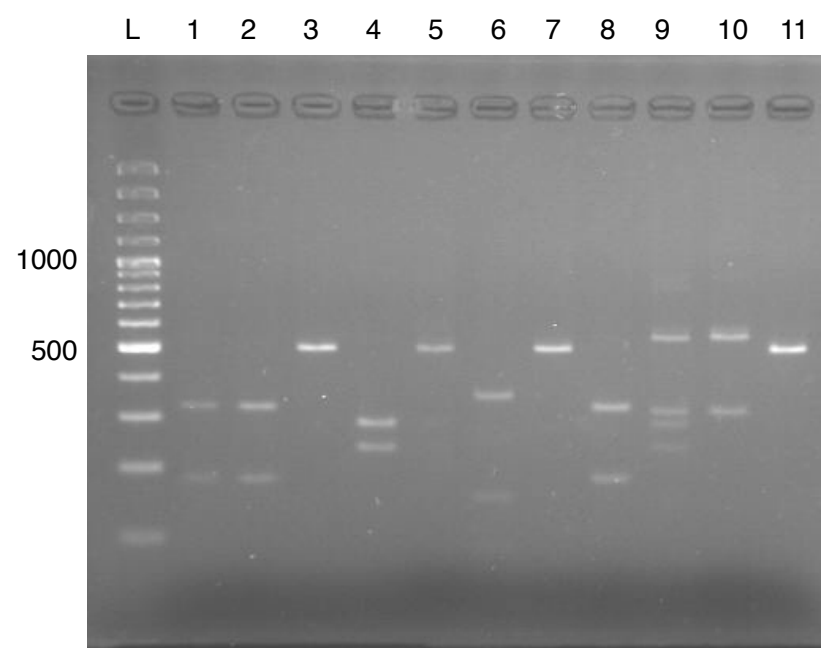

Figura 10 - Gel de agarose mostrando os resultados obtidos por PCR RFLP

Linhas: L, marcador DNA Ladder Plus 100 pb; 1, 2 - Candida tropicalis; 3 - Candida parapsilosis; 4 - Candida albicans; 5 - Candida parapsilosis; 6 - Candida guilliermondii; 7 - Candida parapsilosis; 8 - Candida tropicalis; 9 - Candida albicans + Candida glabrata; 10 - Candida glabrata e 11-Candida parapsilosis. 
Nossos resultados revelam que a técnica PCR multiplex apresentou 57,8\% de falha de especificidade, não identificando 11 das 19 amostras avaliadas. Diferentemente disso, a técnica de RFLP, mostrou-se altamente discriminatória na identificação de espécies de Candida, onde a especificidade foi $94,7 \%$. Comparando a susceptibilidade dos métodos, PCR RFLP apresentou 90,9\% de susceptibilidade, enquanto o PCR multiplex apresentou 42,1\% de susceptibilidade. O PCR RFLP foi 2 vezes mais, sensível que o PCR multiplex, e 1,6 vezes mais, específico (Tabela 9).

Tabela 9 - Comparação entre os métodos moleculares PCR multiplex e PCR RFLP

\begin{tabular}{lll}
\hline Isolados & PCR multiplex & PCR RFLP \\
\hline 2 & Candida albicans & Candida albicans \\
12 & Candida tropicalis & Candida tropicalis \\
17 & Não identificada & Candida parapsilosis \\
19 & Não identificada & Candida tropicalis \\
22 & Não identificada & Candida parapsilosis \\
24 & Candida albicans & Candida albicans \\
25 & Não identificada & Candida parapsilosis \\
33 & Não identificada & Candida intermedia \\
35 & Não identificada & Candida tropicalis \\
54 & Não identificada & Candida parapsilosis \\
55 & Candida tropicalis & Candida tropicalis \\
93 & Não identificada & Não identificada \\
99 & Não identificada & Candida parapsilosis \\
121 & Candida albicans & Candida albicans \\
122 & Candida parapsilosis & Candida parapsilosis \\
137 & Candida guilliermondii & Candida guilliermondii \\
139 & Não identificada & Candida parapsilosis \\
166 & Candida albicans + Candida glabrata & Candida albicans + Candida glabrata \\
175 & Não identificada & Candida parapsilosis \\
\hline & &
\end{tabular}

A identificação dos isolados clínicos, por espectrometria de massas MALDI-TOF, foi realizada como complementar à caracterização molecular das leveduras do gênero Candida, a fim de confrontar sua acurácia frente as técnicas moleculares, PCR multiplex e PCR RFLP. Para isto foram analisados os 19 isolados que apresentaram discrepância entre os métodos de identificação fenotípica e molecular.

A acurácia da espectrometria de massa MALDI-TOF frente aos métodos moleculares para a identificação de Candida parapsilosis, Candida guilliermondii e Candida intermedia foi de $100 \%$. Para Candida tropicalis foi de $75 \%$ e para Candida albicans $66,7 \%$. Por este 
método, não foi possível identificar isolado misto e o isolado que demonstrou perfil de restrição com aproximadamente 400 pb na PCR RFLP foi caracterizado como Kodamaea ohmeri.

Os resultados de todos os métodos realizados para identificação dos 19 isolados que demonstraram discrepância estão apresentados na Tabela 10.

Tabela 10 - Discrepância entre métodos clássicos, moleculares e espectrometria de massas MALDI TOF

\begin{tabular}{|c|c|c|c|c|c|c|}
\hline Isolados & PTG & Meio cromogênico & Provas bioquímcas & PCR multiplex & PCR RFLP & Espectrometria \\
\hline 2 & $\begin{array}{l}\text { Candida não } \\
\text { albicans }\end{array}$ & Candida spp. & Candida famata & Candida albicans & Candida albicans & Candida tropicalis \\
\hline 12 & $\begin{array}{l}\text { Candida não } \\
\text { albicans }\end{array}$ & Candida spp. & Candida guilliermondii & Candida tropicalis & Candida tropicalis & Candida tropicalis \\
\hline 17 & $\begin{array}{l}\text { Candida não } \\
\text { albicans }\end{array}$ & Candida spp. & Candida parapsilosis & Não identificada & Candida parapsilosis & $\begin{array}{l}\text { Candida } \\
\text { parapsilosis }\end{array}$ \\
\hline 19 & $\begin{array}{l}\text { Candida } \\
\text { albicans }\end{array}$ & $\begin{array}{l}\text { Candida albicans }+ \\
\text { Candida tropicalis }\end{array}$ & Candida tropicalis & Não identificada & Candida tropicalis & Candida tropicalis \\
\hline 22 & $\begin{array}{l}\text { Candida não } \\
\text { albicans }\end{array}$ & Candida spp. & Candida parapsilosis & Não identificada & Candida parapsilosis & $\begin{array}{l}\text { Candida } \\
\text { parapsilosis }\end{array}$ \\
\hline 24 & $\begin{array}{l}\text { Candida não } \\
\text { albicans }\end{array}$ & Candida tropicalis & Candida tropicalis & Candida albicans & Candida albicans & Candida albicans \\
\hline 25 & $\begin{array}{l}\text { Candida não } \\
\text { albicans }\end{array}$ & Candida spp. & Candida parapsilosis & Não identificada & Candida parapsilosis & $\begin{array}{l}\text { Candida } \\
\text { parapsilosis }\end{array}$ \\
\hline 33 & $\begin{array}{l}\text { Candida não } \\
\text { albicans }\end{array}$ & Candida spp. & Candida famata & Não identificada & Candida intermedia & C. intermedia \\
\hline 35 & $\begin{array}{l}\text { Candida não } \\
\text { albicans }\end{array}$ & Candida krusei & Candida krusei & Não identificada & Candida tropicalis & Candida krusei \\
\hline 54 & $\begin{array}{l}\text { Candida não } \\
\text { albicans }\end{array}$ & Candida spp. & Candida famata & Não identificada & Candida parapsilosis & $\begin{array}{l}\text { Candida } \\
\text { parapsilosis }\end{array}$ \\
\hline 55 & $\begin{array}{l}\text { Candida } \\
\text { albicans }\end{array}$ & Candida albicans & Candida albicans & Candida tropicalis & Candida tropicalis & Candida tropicalis \\
\hline 93 & $\begin{array}{l}\text { Candida não } \\
\text { albicans }\end{array}$ & Candida spp. & Candida famata & Não identificada & Não identificada & Kodameae ohmeri \\
\hline 99 & $\begin{array}{l}\text { Candida não } \\
\text { albicans }\end{array}$ & Candida spp. & Candida famata & Não identificada & Candida parapsilosis & $\begin{array}{l}\text { Candida } \\
\text { parapsilosis }\end{array}$ \\
\hline 121 & $\begin{array}{l}\text { Candida não } \\
\text { albicans }\end{array}$ & Candida spp. & Candida parapsilosis & Candida albicans & Candida albicans & Candida albicans \\
\hline 122 & $\begin{array}{l}\text { Candida não } \\
\text { albicans }\end{array}$ & Candida spp. & Candida glabrata & Candida parapsilosis & Candida parapsilosis & $\begin{array}{l}\text { Candida } \\
\text { parapsilosis }\end{array}$ \\
\hline 137 & $\begin{array}{l}\text { Candida não } \\
\text { albicans }\end{array}$ & Candida spp. & Candida famata & Candida guilliermondi & Candida guilliermondii & $\begin{array}{l}\text { Candida } \\
\text { guilliermondii }\end{array}$ \\
\hline 139 & $\begin{array}{l}\text { Candida não } \\
\text { albicans }\end{array}$ & Candida spp. & Candida famata & Não identificada & C. parapsilosis & $\begin{array}{l}\text { Candida } \\
\text { parapsilosis }\end{array}$ \\
\hline 166 & $\begin{array}{l}\text { Candida } \\
\text { albicans }\end{array}$ & $\begin{array}{l}\text { Candida albicans }+ \\
\text { Candida glabrata }\end{array}$ & Candida glabrata & $\begin{array}{l}\text { Candida albicans }+ \\
\text { Candida glabrata }\end{array}$ & $\begin{array}{l}\text { Candida albicans }+ \\
\text { Candida glabrata }\end{array}$ & Candida tropicalis \\
\hline 175 & $\begin{array}{l}\text { Candida } \\
\text { albicans }\end{array}$ & Candida albicans & Candida albicans & Não identificada & Candida parapsilosis & $\begin{array}{l}\text { Candida } \\
\text { parapsilosis }\end{array}$ \\
\hline
\end{tabular}

Para análise final dos resultados, a técnica de PCR RFLP foi considerada decisiva dada sua elevada especificidade. Além disso, os resultados obtidos por PCR RFLP foram corroborados pela técnica de MALDI-TOF que apresentou concordância de 84,2\% com o PCR RFLP. Os 15,8\% de amostras discordantes na técnica de MALDI-TOF foram representados por 3 isolados (2, 35 e 166), que foram descartados e, neste caso, novamente os dados do PCR RFLP foram considerados corretos. 
Analisando o método de PTG e comparando com o método de PCR RFLP, verificamos que amostras produtoras de tubo germinativo e classificadas como Candida albicans, foram identificadas como Candida tropicalis (isolados 19 e 55) e Candida parapsilosis (isolados 175), e amostras não produtoras de tubo germinativo, portanto consideradas não albicans neste método, foram classificadas como Candida albicans (isolados 2, 24 e 121). Além disso, o isolado 166 considerado misto Candida albicans e Candida glabrata melo método PCR RFLP, foi identificado como Candida albicans pelo método PTG.

Quanto à identificação de isolados mistos, o método de PTG, embora basei-se apenas em características morfológicas, apresentou resultado coerente porque evidenciou a presença de tubo germinativo em algumas leveduras, o que a rigor identificaria esta levedura como Candida albicans. Entretanto, ficou evidente que o método apresenta limitações e pode falhar em situações onde mais de um tipo de levedura esteja presente.

No meio cromogênico, 7 isolados $(2,19,24,35,55,121$ e 175) apresentaram resultados discordantes quando comparados com o método de PCR RFLP. As falhas encontradas chamam atenção porque o método possui a capacidade de distinguir as espécies de Candida albicans, Candida tropicalis e Candida krusei, e falhou exatamente na identificação destas espécies (isolados 2, 24, 35, 55, 121 e 175). Além disso, o método apresenta grande capacidade de identificar isolados mistos e apresentou falhas exatamente na identificação do isolado 19, que foi confirmado pelo método de PCR RFLP como Candida tropicalis.

Avaliando os resultados das provas bioquímicas, encontramos as falhas de identificação mais importantes, o percentual de concordância foi de apenas $21 \%$, quando comparado ao método PCR RFLP. O erro de identificação mais relevante foi relacionado a identificação de Candida famata, 100\% das amostras apresentaram identificação errada comparada com o método PCR RFLP, e nenhuma identificação de amostras mistas foi encontrada.

O resultado final da caracterização dos isolados clínicos demonstrou que, Candida albicans foi a espécie mais isolada 50,6\% $(\mathrm{n}=76)$ seguida de Candida parapsilosis 21,3\% $(\mathrm{n}=32)$, Candida tropicalis $16,6 \%(\mathrm{n}=25)$, Candida glabrata $8 \%(\mathrm{n}=12)$, Candida krusei $0,7 \% \quad(\mathrm{n}=1)$, Candida guilliermondii $0,7 \% \quad(\mathrm{n}=1)$, Candida intermedia $0,7 \% \quad(\mathrm{n}=1)$ e 
Kodamaea ohmeri $0,7 \%(\mathrm{n}=1)$. Ainda foi detectado $1(0,7 \%)$ isolado misto constituido de Candida albicans e Candida glabrata (Figura 11).

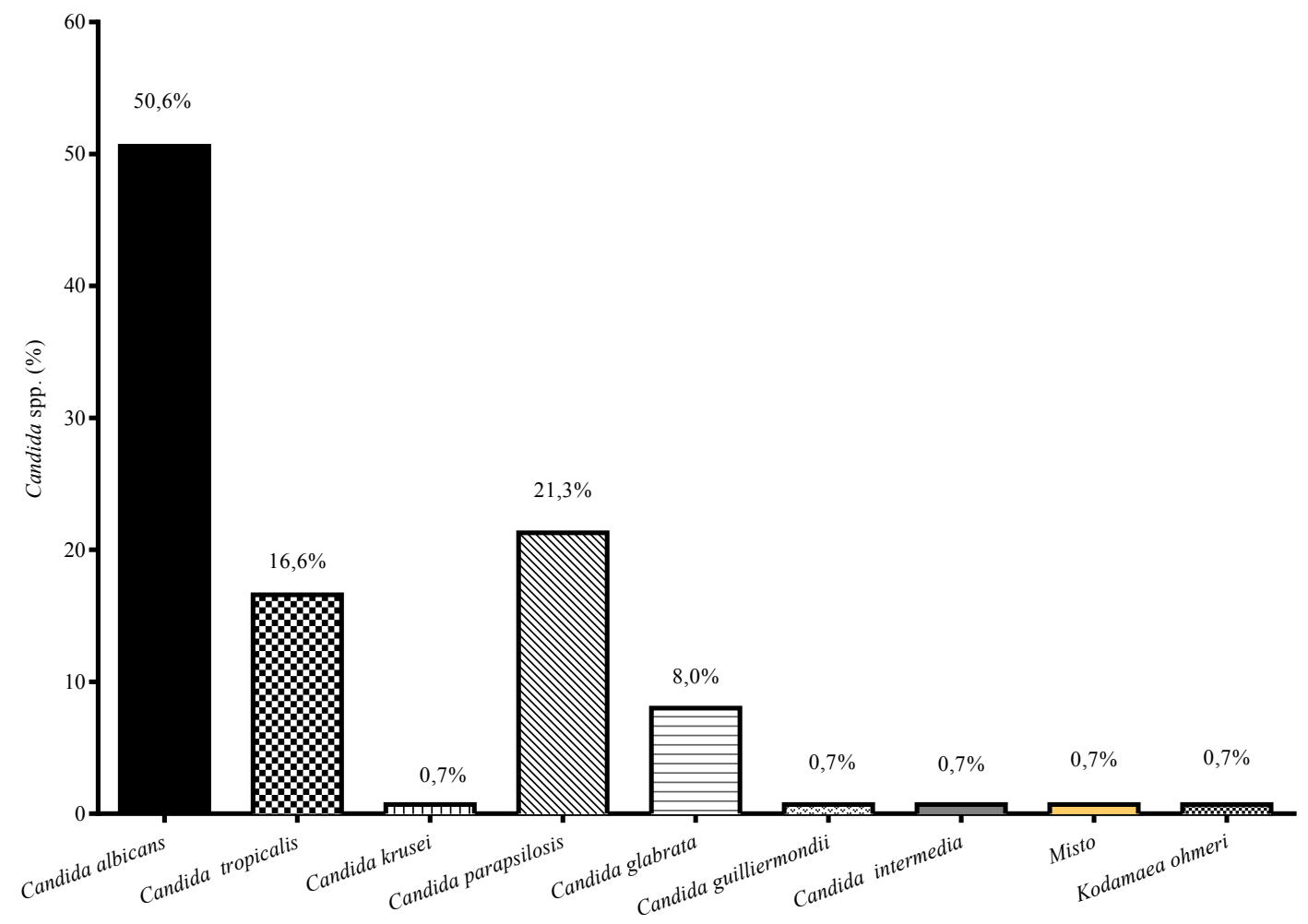

Figura 11 - Resultados final da identificação dos isolados clínicos

\subsection{Aspectos epidemiológicos dos isolados clínicos}

No presente estudo, Candida albicans $(50,6 \%)$ foi a mais prevalente de todas as espécies isoladas de materiais biológicos de pacientes com suspeita clínica de infecções sistêmicas, no Distrito Federal, entre Janeiro de 2011 a Dezembro de 2012 e, as espécies de Candida não albicans demonstraram percentual de 49,4\%.

A predominância de Candida albicans, em casos de candidíase sistêmica, é evidenciada em várias regiões do Brasil e do mundo. Em todo o mundo, tem sido observado variabilidade do percentual de espécies de Candida não albicans, que era considerada irrelevante até a última década e passou a ganhar importância com o crescente aumento de sua prevalência nos casos de candidíase sistêmica (PLALLER et al., 2015; NEUFELD et al., 2015; MENEZES et al., 2015; MAGALHÃES et al., 2015). 
Neste estudo, foram isoladas entre as espécies não albicans: Candida parapsilosis 21,3\%, Candida tropicalis 16,6\%, Candida glabrata 8\%, Candida krusei 0,7\%, Candida guilliermondii $0,7 \%$ e Candida intermedia $0,7 \%$. O ranque de prevalência destas espécies é variável e pode estar associado a alguns fatores como a fonte de material biológico em que foi isolada a levedura, o perfil clínico do paciente (hematológico, transplantados, oncológico, cirúrgico, entre outros), uso constante e prolongado de determinados antifúngicos, idade, entre outros (CORNISTEIN et al., 2013; COSTA et al., 2014; COLOMBO et al., NG et al., 2015).

Na América Latina, a prevalência observada de espécies não albicans é semelhante a encontrada em nossos resultados, Candida parapsilosis, Candida tropicalis, Candida glabrata, Candida krusei, Candida guilliermondii e outras. Já na América do Norte, esse perfil de prevalência ocorre com: Candida glabrata, Candida parapsilosis, Candida tropicalis, Candida krusei, Candida guilliermondii e outras. Na Europa, a ocorrência de prevalência é Candida parapsilosis, Candida glabrata, Candida tropicalis, Candida krusei, Candida guilliermondii e outras (PFALLER et al., 2015).

Dados de prevalência no Brasil apresentam um perfil de prevalência que muda de região para região. No Estado do Rio de Janeiro Candida parapsilosis, Candida tropicalis, Candida guilliermondii, Candida famata, Candida glabrata, Candida krusei e Candida lambica (NEUFELD et al., 2015). No Estado de Minas Gerais (Uberlândia), a espécie de Candida parapsilosis foi mais prevalente que Candida albicans, seguido de Candida tropicalis e outras (MENEZES et al., 2015). No Estado do Maranhão, em São Luís, a prevalência encontrada foi de Candida tropicalis, Candida glabrata, Candida parapsilosis, Candida krusei, Candida norvegensis (MAGALHÃES et al., 2015).

Com relação à distribuição em materiais biológicos, Candida albicans foi isolada principalmente de lavado broncoalveolar $(n=37)$, escarro $(n=16)$ e sangue $(n=13)$. A maioria das espécies de Candida parapsilosis $(\mathrm{n}=17)$ e Candida tropicalis $(\mathrm{n}=8)$ foi recuperada de amostras de sangue, Candida glabrata $(\mathrm{n}=6)$ foi mais isolada de lavado broncoalveolar, Candida krusei $(\mathrm{n}=1)$, Candida guilliermondii $(\mathrm{n}=1)$ e $K$. ohmeri $(\mathrm{n}=1)$ foram isoladas de amostras do trato respiratório, Candida intermedia $(\mathrm{n}=1)$ foi isolada de amostra de urina e a suspeita de infecção mista ocorreu em amostra de lavado brônquico (n=1) (Tabela 11). 
Tabela 11 - Distribuição das espécies de leveduras por materiais biológicos

\begin{tabular}{llllllllll}
\hline Materiais biológicos & Calb & Cpar & Cgla & Ctro & Ckru & Cgui & Cint & Kohm & Misto \\
\hline Lavado broncoalveolar & 37 & 2 & 6 & 6 & 0 & 1 & 0 & 1 & 1 \\
Sangue & 13 & 17 & 1 & 9 & 0 & 0 & 0 & 0 & 0 \\
Escarro & 16 & 3 & 3 & 7 & 1 & 0 & 0 & 0 & 0 \\
Fragmento de tecido & 3 & 3 & 0 & 1 & 0 & 0 & 0 & 0 & 0 \\
Urina & 3 & 2 & 0 & 1 & 0 & 0 & 1 & 0 & 0 \\
Líquor & 2 & 3 & 0 & 0 & 0 & 0 & 0 & 0 & 0 \\
Secreções & 2 & 1 & 1 & 0 & 0 & 0 & 0 & 0 & 0 \\
Líquidos corporais & 0 & 0 & 1 & 1 & 0 & 0 & 0 & 0 & 0 \\
Ponta de cateter & 0 & 1 & 0 & 0 & 0 & 0 & 0 & 0 & 0 \\
\hline
\end{tabular}

Candida albicans (Calb), Candida parapsilosis (Cpar), Candida glabrata (Cgla), Candida tropicalis (Ctro), Candida krusei (Ckru), Candida guilliermondii (Cgui), Candida intermedia (Clus) e Kodamaea ohmeri (Kohm)

Quanto à faixa etária, foi observado que Candida albicans $(\mathrm{n}=46)$ e Candida glabrata $(\mathrm{n}=8)$ foram mais frequentes em pacientes entre 21 a 60 anos de idade. Candida parapsilosis foi isolada e, tanto em pacientes mais jovens, 0 a 20 anos $(n=13)$, como em pacientes com 21 a 60 anos $(\mathrm{n}=12)$. O isolamento de Candida tropicalis foi predominante em pacientes na faixa etária acima de 60 anos $(\mathrm{n}=13)$. Os isolados de Candida krusei $(\mathrm{n}=1)$ e Candida guilliermondii $(\mathrm{n}=1)$ foram recuperados de paciente na faixa etária de 21 a 60 anos e os isolados de Candida intermedia $(\mathrm{n}=1)$, Kodamaea ohmeri $(\mathrm{n}=1)$ e misto $(\mathrm{n}=1)$ foram isolados de pacientes com idade acima de 60 anos (Tabela 12).

De fato, há relatos na literatura que algumas espécies de Candida não albicans possuem relação de prevalência ligada à faixa etária. Em revisão, Lockhart e e colaboradores (2014) citam, que Candida albicans e Candida tropicalis são organismos mais comuns em adultos, Candida glabrata é frequente em pacientes idosos, corresponde à terceira espécie mais prevalente em crianças, e é relativamente rara em neonatos. Enquanto Candida parapsilosis é a segunda mais prevalente em pacientes pediátricos.

Tabela 12 - Distribuição das espécies de leveduras por faixa etária

\begin{tabular}{llllllllll}
\hline Idade & Calb & Cpar & Cgla & Ctro & Ckru & Cgui & Cint & Kohm & Misto \\
\hline $0-20$ & 9 & 13 & 0 & 2 & 0 & 0 & 0 & 0 & 0 \\
$21-60$ & 46 & 12 & 8 & 10 & 1 & 1 & 0 & 0 & 0 \\
Acima de 60 & 21 & 7 & 4 & 13 & 0 & 0 & 1 & 1 & 1
\end{tabular}

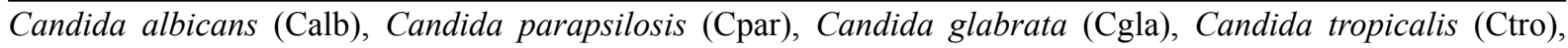
Candida krusei (Ckru), Candida guilliermondii (Cgui), Candida intermedia (Clus) e Kodamaea ohmeri (Kohm)

Com relação ao gênero, houve predominância de isolamento das leveduras no sexo masculino, Candida albicans $(\mathrm{n}=51)$, Candida parapsilosis $(\mathrm{n}=20)$, Candida tropicalis 
$(\mathrm{n}=17)$, Candida glabrata $(\mathrm{n}=8)$, K. ohmeri $(\mathrm{n}=1)$, Candida guilliermondii $(\mathrm{n}=1)$ e isolado misto ( $\mathrm{n}=1)$ (Tabela 13).

Tabela 13 - Distribuição das espécies de leveduras por gênero

\begin{tabular}{llllllllll}
\hline Sexo & Calb & Cpar & Cgla & Ctro & Ckru & Cgui & Cint & Kohm & Misto \\
\hline Feminino & 25 & 12 & 4 & 8 & 1 & 0 & 1 & 0 & 0 \\
Masculino & 51 & 20 & 8 & 17 & 0 & 1 & 0 & 1 & 1 \\
\hline
\end{tabular}

Candida albicans (Calb), Candida parapsilosis (Cpar), Candida glabrata (Cgla), Candida tropicalis (Ctro), Candida krusei (Ckru), Candida guilliermondii (Cgui), Candida intermedia (Clus) e Kodamaea ohmeri (Kohm)

Referente à espécie de leveduras não Candida, Kodamaea ohmeri consiste em espécie raramente associada a infecções, embora esteja envolvida na ocorrência de casos de fungemia (BERGMAN et al., 1998; MATUTE et al., 2000; HITOMI et al., 2002; SHIN et al., 2003; HAN et al., 2004), peritonite (CHOY; WONG, 2000), endocardite (JOÃO et al., 2002; REINA; LARONE, 2002) e infecções de feridas (HAN et al., 2004).

Em relação à ocorrência de infecções mistas, prevalente $0,7 \%$ em nosso estudo, sabese que geralmente ocorrem com Candida albicans e, Candida glabrata, Candida tropicalis ou Candida krusei. Entretanto poucos estudos evidenciam as interações ecológicas entre estas espécies. Em estudo recente, Rossoni e colaboradores (2015) demonstraram que, em modelo animal, Candida albicans isolada é mais agressiva do que quando presente nas infecções mistas com Candida não albicans, sugerindo que Candida albicans estabelece uma interação competitiva com Candida krusei e Candida glabrata durante formação de biofilme e desenvolvimento de candidíase experimental.

\subsection{Perfil de susceptibilidade dos isolados clínicos aos agentes antifúngicos convencionais}

O perfil de susceptibilidade frente a voriconazol $(1 \mu \mathrm{g})$, fluconazol $(25 \mu \mathrm{g})$, itraconazol $(10 \mu \mathrm{g}), 5$-fluorocitosina $(1 \mu \mathrm{g})$ e anfotericina B $(100 \mu \mathrm{g})$ foi determinado para os 148 isolados clínicos de Candida spp e para o isolado de Kodamaea ohmeri. O isolado misto foi excluído, pois a realização do teste de disco difusão, com amostras contendo dois ou mais microrganismos, de acordo com o documento M44-A consiste em parâmetro fora dos padrões e pode acarretar erros de interpretação dos resultados (CLSI, 2004). 
A faixa de variação dos diâmetros de inibição, para cada antifúngico foi de 0 a $50 \mathrm{~mm}$ para voriconazol $(1 \mu \mathrm{g}), 0$ a $50 \mathrm{~mm}$ para fluconazol $(25 \mu \mathrm{g}), 0$ a $30 \mathrm{~mm}$ para itraconazol $(10 \mu \mathrm{g}), 0$ a $30 \mathrm{~mm}$ para 5 -fluorocitosina $(1 \mu \mathrm{g})$ e 10 a $30 \mathrm{~mm}$ para anfotericina B $(100 \mu \mathrm{g})$.

As cepas padrões (ATCC) de Candida parapsilosis (ATCC 22019) e Candida albicans (ATCC 90028), utilizadas como controle, apresentaram resultados compatíveis com a literatura, garantindo a execução e condições do teste (CLSI, 2004) (Tabela 14).

Tabela 14 - Diâmetros dos halos de inibição para as cepas padrões ATCC

\begin{tabular}{lccccc}
\hline \multirow{2}{*}{ Agentes antifúngicos } & Carga & \multicolumn{2}{c}{ Candida parapsilosis ATCC22019 } & \multicolumn{2}{c}{ Candida albicans ATCC90028 } \\
\cline { 2 - 6 } & & $\begin{array}{c}\text { Diâmetro (mm) } \\
\text { obtido }\end{array}$ & $\begin{array}{c}\text { Diâmetro (mm) } \\
\text { recomendado }\end{array}$ & $\begin{array}{c}\text { Diâmetro (mm) } \\
\text { obtido }\end{array}$ & $\begin{array}{c}\text { Diâmetro (mm) } \\
\text { recomendado }\end{array}$ \\
\hline Voriconazol & $1 \mu \mathrm{g}$ & 37 & $28-37$ & 40 & $31-42$ \\
Fluconazol & $25 \mu \mathrm{g}$ & 33 & $22-33$ & 39 & $28-39$ \\
\hline
\end{tabular}

No presente estudo, os isolados de Candida albicans $(\mathrm{n}=76)$ montraram susceptibilidade a voriconazol (76S), fluconazol (76S), itraconazol (69S) e anfotericina B (74S) e, exibiram susceptibilidade reduzida a 5-fluorocitosina (65R e 11SDD), itraconazol (1R e 6SDD) e anfotericina B (2R) (Figura 12).
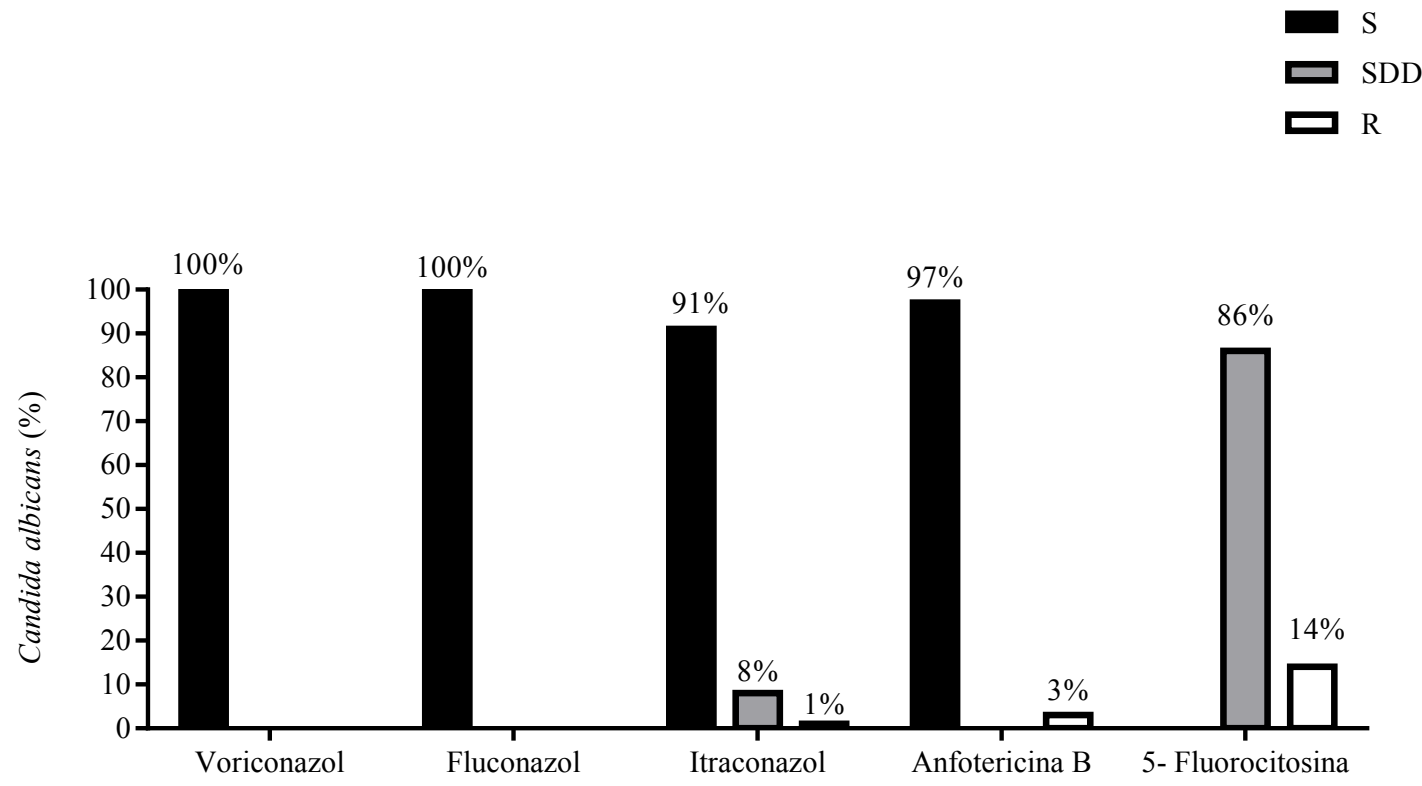

Figura 12 - Perfil de susceptibilidade de Candida albicans aos agentes antifúngicos convencionais Sensível (S), Resistente (R) e Sensível Dose Dependente (SDD) 
Os isolados de Candida parapsiolosis $(\mathrm{n}=32)$ também monstraram susceptibilidade a voriconazol (32S), fluconazol (31S), itraconazol (16S) e anfotericina B (32S) e apresentaram alta taxa de resistência à 5-fluorocitosina (32R). Além disso, alguns isolados exibiram susceptibilidade reduzida a fluconazol (1R) e a itraconazol (2R e 14SDD) (Figura 13).

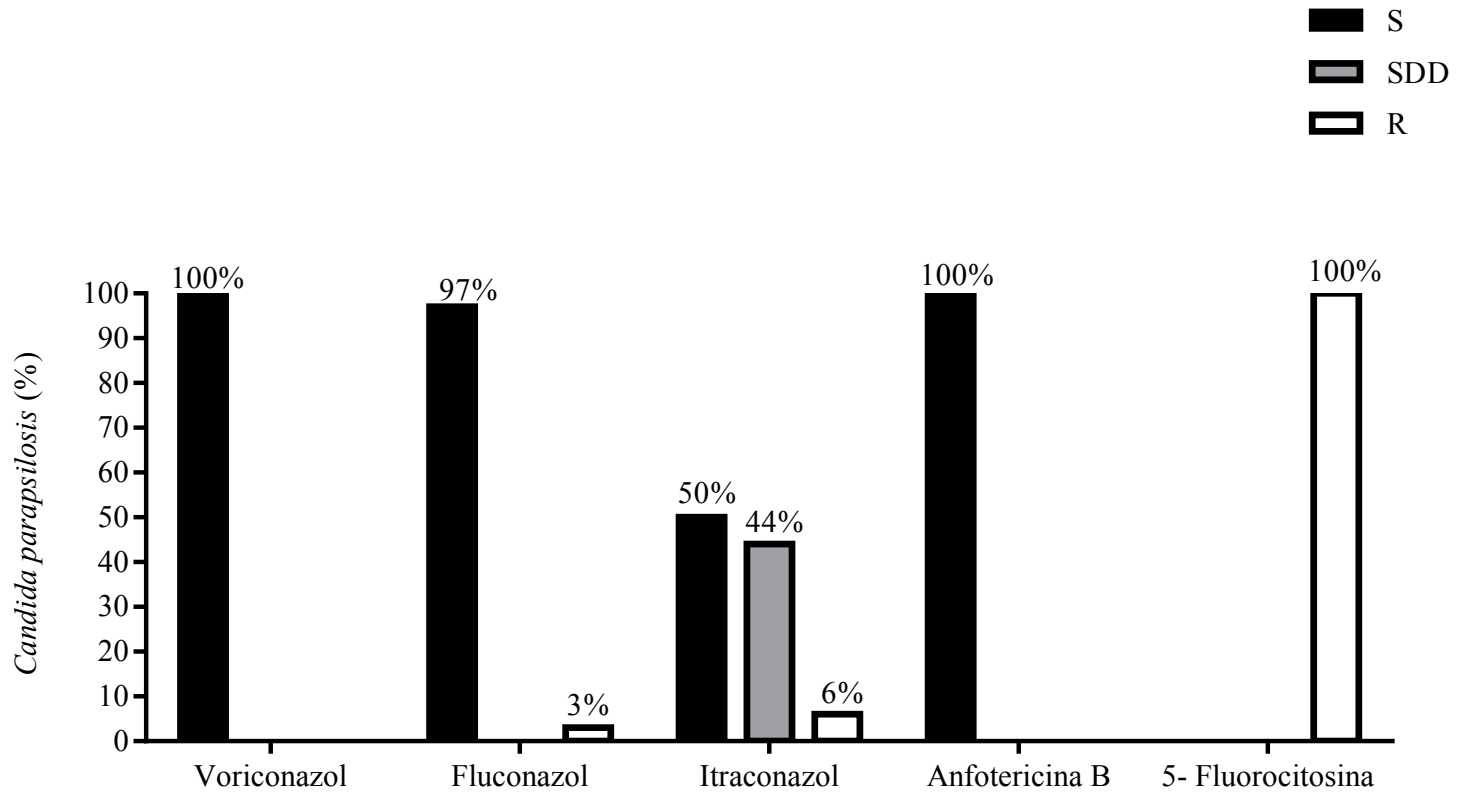

Figura 13 - Perfil de susceptibilidade de Candida parapsilosis aos agentes antifúngicos convencionais

Sensível (S), Resistente (R) e Sensível Dose Dependente (SDD)

Os isolados de Candida tropicalis $(\mathrm{n}=25)$ apresentaram susceptibilidade a todos os antifúngicos, com taxas mais elevadas para voriconazol (25S), fluconazol (25S), itraconazol (21S) e anfotericina B (24S) e taxa menor para 5-fluorocitosina (4S). Quanto à sensibilidade reduzida a este antifúngico foram observadas para anfotericina B (1R), itraconazol (4SDD) e 5-fluorocitosina (17R e 4SDD) (Figura 14). 


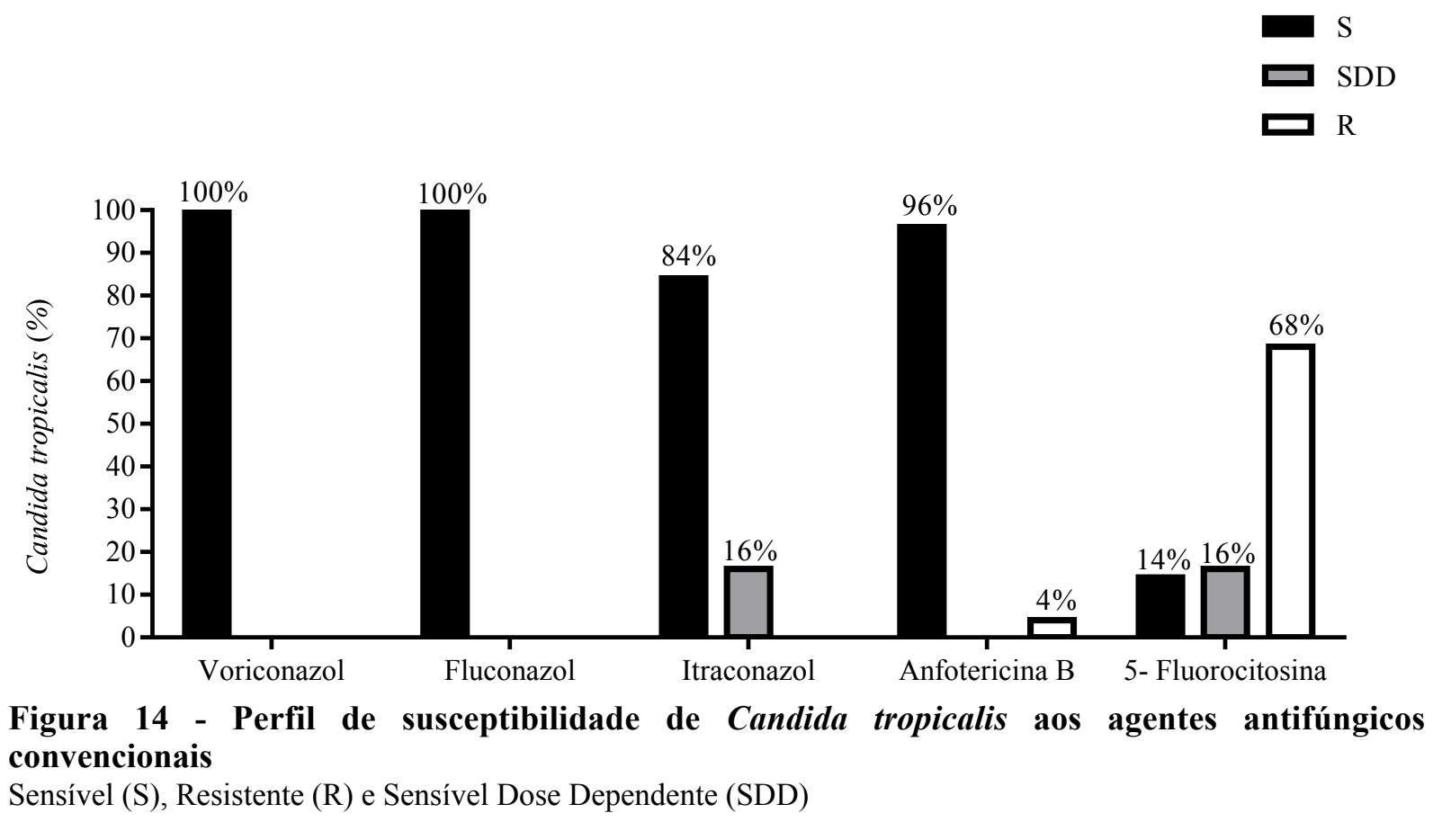

Os isolados de Candida glabrata $(\mathrm{n}=12)$ apresentaram elevada taxa de resistência à voriconazol (11R), fluconazol (11R), itraconazol (11R) e 5-flurocitosina (12R) e, monstram-se altamente sensíveis à anfotericina B (12S) (Figura 15).

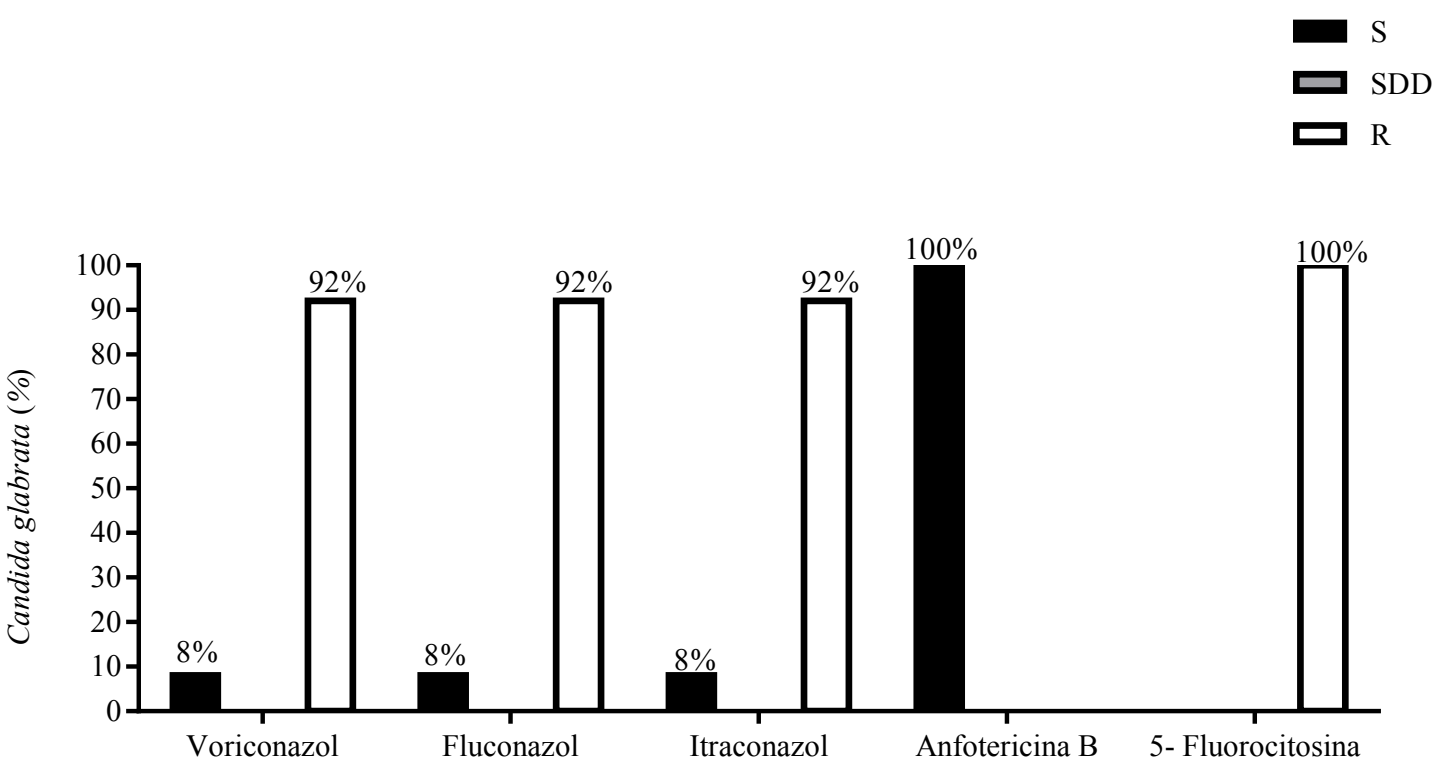

Figura 15 - Perfil de susceptibilidade de Candida glabrata aos agentes antifúngicos convencionais Sensível (S), Resistente (R) e Sensível Dose Dependente (SDD)

O isolado de Candida krusei $(\mathrm{n}=1)$ foi sensível a voriconazol, fluconazol e anfotericina $\mathrm{B}$ e, demonstrou susceptibilidade reduzida a itraconazol (1SDD) e à 5- 
fluorocitosina (1R), o isolado de Candida guilliermondii $(\mathrm{n}=1)$ apresentou susceptibilidade a voriconazol, fluconazol, itraconazol e anfotericina $\mathrm{B}$ e foi resistente somenteà 5fluorocitosina, o isolado de Candida intermedia $(\mathrm{n}=1)$ foi sensível apenas à anfotericina $\mathrm{B}$ e foi resistente a voriconazol, fluconazol, itraconazol e 5-fluorocitosina e o isolado de Kodamaea ohmeri foi sensível a voriconazol, fluconazol, itraconazol e anfotericina B e resistente à 5-fluorocitosina (Tabela 15).

Tabela 15 - Perfil de susceptibilidade de Candida krusei, Candida guilliermondii, Candida intermedia e K. ohmeri aos agentes antifúngicos convencionais

\begin{tabular}{llllll}
\hline $\begin{array}{l}\text { Agentes } \\
\text { antifúngicos }\end{array}$ & Carga & $\begin{array}{l}\text { Candida } \\
\text { krusei }\end{array}$ & $\begin{array}{l}\text { Candida } \\
\text { guilliermondii }\end{array}$ & $\begin{array}{l}\text { Candida } \\
\text { intermedia }\end{array}$ & $\begin{array}{l}\text { Kodamaea } \\
\text { ohmeri }\end{array}$ \\
\hline Voriconazol & $1 \mu \mathrm{g}$ & $\mathrm{S}$ & $\mathrm{S}$ & $\mathrm{R}$ & $\mathrm{S}$ \\
Fluconazol & $25 \mu \mathrm{g}$ & $\mathrm{S}$ & $\mathrm{S}$ & $\mathrm{R}$ & $\mathrm{S}$ \\
Itraconazol & $10 \mu \mathrm{g}$ & $\mathrm{SDD}$ & $\mathrm{S}$ & $\mathrm{R}$ & $\mathrm{S}$ \\
5-Fluorocitosina & $1 \mu \mathrm{g}$ & $\mathrm{R}$ & $\mathrm{R}$ & $\mathrm{R}$ & $\mathrm{R}$ \\
Anfotericina B & $100 \mu \mathrm{g}$ & $\mathrm{S}$ & $\mathrm{S}$ & $\mathrm{S}$ & $\mathrm{S}$ \\
\hline
\end{tabular}

Observa-se que a maioria dos isolados clínicos monstraram susceptibilidade à anfotericina B (97,9\%; $n=146)$, voriconazol $(91,9 \% ; n=137)$, fluconazol $(91,3 \% ; n=136)$ e itraconazol $(67 \% ; n=109)$, e 97,3\% $(n=145)$ dos isolados exibiram susceptibilidade reduzida a 5-fluorocitocina (Figura 16).

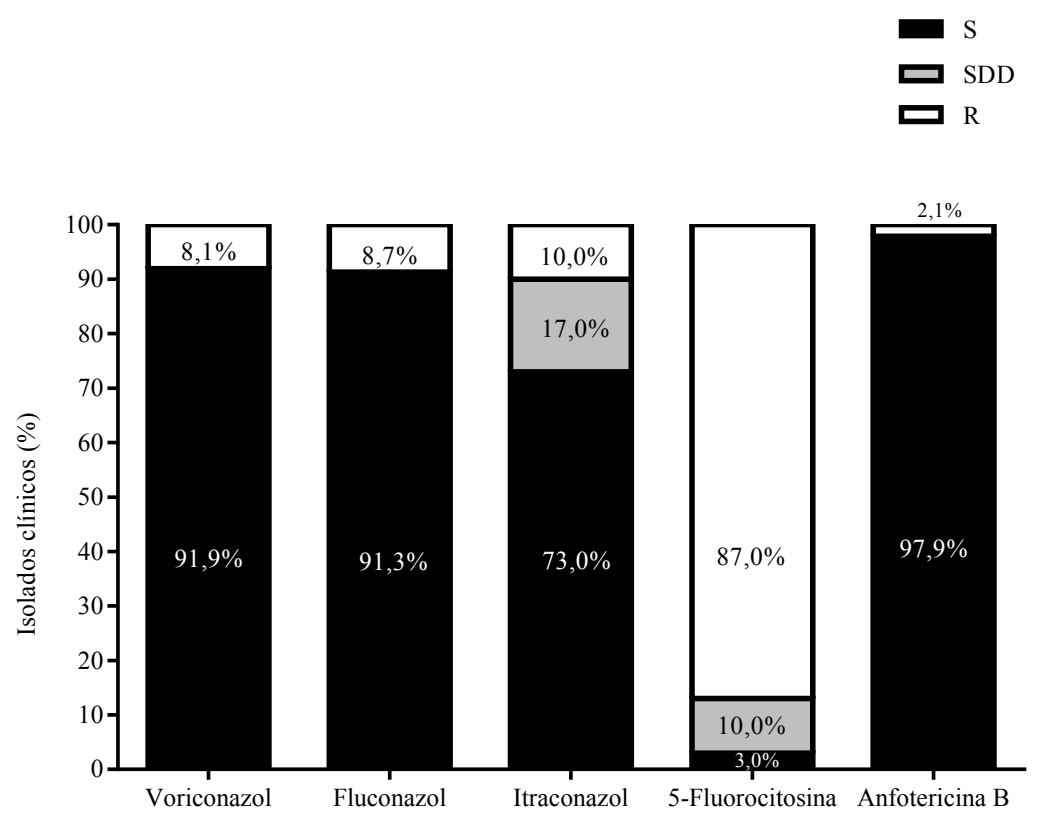

Figura 16 - Perfil de susceptibilidade de todos os isolados clínicos aos agentes antifúngicos convencionais

Sensível (S), Resistente (R) e Sensível Dose Dependente (SDD) 
Este perfil é relatado em vários estudos (COLOMBO et al., 2006; KALKANCI et al., 2007; CHANG et al., 2013; COSTA et al., 2014; RAZZAGHI-ABYANEH et al., 2014; ZHANG et al., 2015) No entanto, sofre variações de acordo com a região geográfica. Além disso, a resistência adquirida por espécies de Candida frequentemente está associada ao uso de terapia profiláticas, que contribui de forma direta com o aumento de espécies de Candida não albicans, que são naturalmente menos sensíveis aos antifúngicos e também possuem maior capacidade de desenvolver resistência cruzada, principalmente aos agentes azólicos (CHANDER, 2013).

A resistência cruzada, tem sido principal causa de falha terapêutica de infecções fúngicas, e é definida como a resistência de micro-organismos a várias drogas que compartilham alvos terapêuticos em comum (CHANDER, 2013). Em nosso estudo, algunas espécies de Candida também monstraram múltiplas resistências. Candida glabrata e Candida intermedia foram resistentes a voriconazol, fluconazol, itraconazol. Estas espécies também monstraram resistência a 5-fluorocitosina, podendo ser classificadas também como multirresistentes. Outras espécies de Candida, monstraram resistência a três ou dois antifúngicos como: Candida tropicalis e Candida parapsilosis foram resistentes a fluconazol, itraconazol e 5-fluorocitosina. Candida albicans e Candida parapsilosis foram resistentes a itraconazol e 5-fluorocitosina e Candida albicans e Candida tropicalis foram resistentes a 5fluorocitocina e anfotericina B (Figura 17).

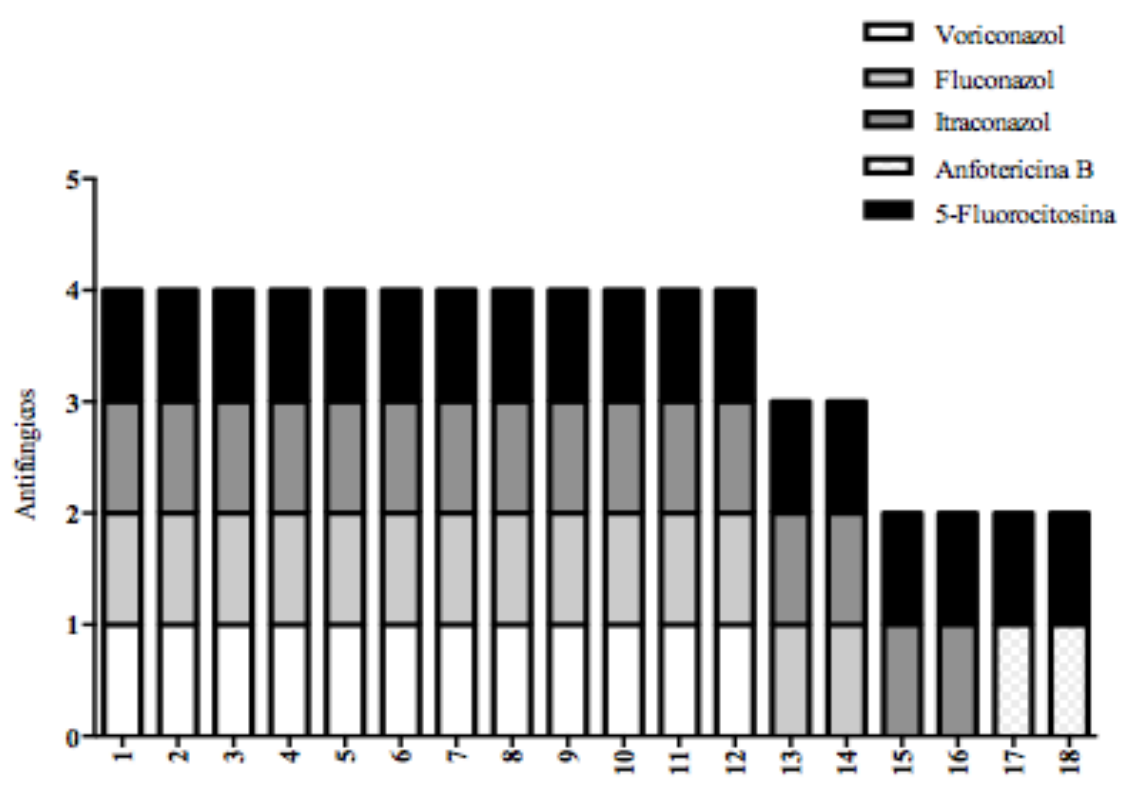

Figura 17 - Isolados clínicos com múltiplas resistências

Candida glabrata (1-11), Candida intermedia (12), Candida tropicalis (13), Candida parapsilosis (14), Candida albicans (15-16), Candida tropicalis (17), Candida parapsilosis (18). 


\subsection{Atividade antifúngica de extratos brutos vegetais}

Inicialmente, foram testados os extratos brutos vegetais de Eugenia dysenterica (A), Pouteria ramiflora (A, E), Pouteria torta (E), Erythroxylum subrotundum (A, E), Erythroxylum daphnites (A, E) e Bauhinia rufa (A, E) sobre cepas padrões de Candida albicans (ATCC 90028), Candida parapsilosis (ATCC 22019), Candida tropicalis (ATCC 28707), Candida glabrata (ATCC 2001), Candida guilliermondii (ATCC 6260), Candida krusei (ATCC 34135) e Candida famata (ATCC 62894), com a finalidade de selecionar extratos com atividade antifúngica.

Dos dez extratos testados, nove extratos exibiram atividade contra pelo menos uma cepa padrão, entre eles, todos os extratos aquosos (5/5) e a maioria dos extratos etanólicos (4/5). A atividade inibitória dos extratos foi caracterizada pela formação de halo de inibição com diâmentro $\geqq 10 \mathrm{~mm}$.

Os valores máximos dos diâmetros de inibição, para os extratos aquosos, foi de $15 \mathrm{~mm}$ para Eugenia dysenterica; 20mm para Pouteria ramiflora, $30 \mathrm{~mm}$ para Erythroxylum subrotundum, $24 \mathrm{~mm}$ para Erythroxylum daphnites e $25 \mathrm{~mm}$ para Bauhinia rufa. Para os extratos etanólicos, foi $23 \mathrm{~mm}$ para Pouteria ramiflora: $15 \mathrm{~mm}$ para Pouteria torta; $20 \mathrm{~mm}$ para Erythroxylum subrotundum e $25 \mathrm{~mm}$ para Bauhinia rufa. O extrato etanólico de Erythroxylum daphnites não foi ativo contra nenhuma cepa, mesmo na maior concentração testada $(1000 \mu \mathrm{g})$ (Figura 18).

A

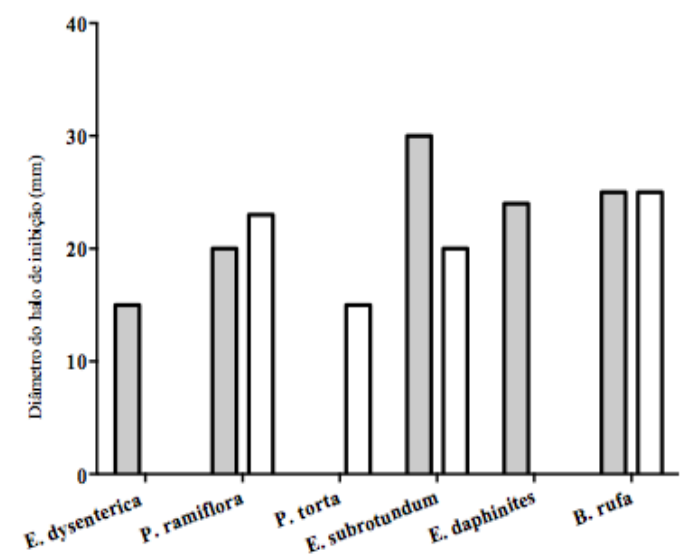

B

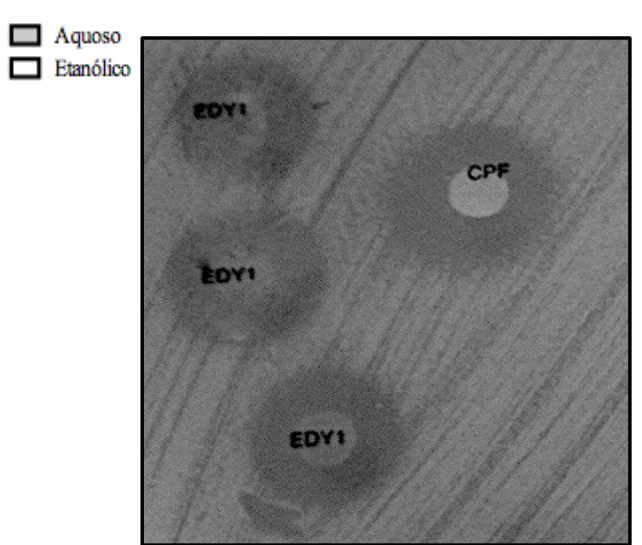

Figura 18 - Extratos brutos vegetais com atividade antifúngica

(A) Valores máximos dos diâmetros de inibição dos extratos ativos (B) Halos de inibição do extrato aquoso de

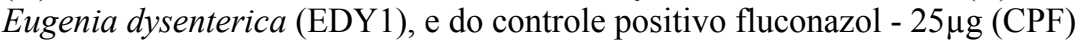


Entre os extratos ativos, o extrato aquoso de Eugenia dysenterica inibiu cinco das sete espécies de Candida, exceto Candida glabrata e Candida albicans. Foi ativo contra Candida parapsilosis (15mm), Candida guillermondii (12mm), Candida tropicais (12mm), Candida krusei (13mm) e Candida famata (12mm).

O extrato etanólico de Pouteria ramiflora foi ativo contra três espécies de Candida, com halos de inibição de $23 \mathrm{~mm}$ (Candida glabrata), 13mm (Candida tropicalis) e 10mm (Candida krusei). Da mesma foram, o extrato etanólico de Pouteria torta e o extrato aquoso de Erythroxylum subrotundum, inibiram três espécies e apresentaram atividade antifúngica contra as mesmas espécies, Candida glabrata (15 e 30mm), Candida parapsilosis (10 e $11 \mathrm{~mm})$ e Candida guilliermondii (10 e 10mm).

O extrato etanólico de Erythroxylum subrotundum e o extrato aquoso de Bauhinia rufa apresentaram halo de inibição de $10 \mathrm{~mm}$ para Candida parapsilosis e halos de 20 e $25 \mathrm{~mm}$ para Candida glabrata, respectivamente. O extrato aquoso de Pouteria ramiflora inibiu duas espécies de Candida (Candida glabrata - 20mm e Candida tropicalis - 14mm) e os extratos de E.rythroxylum daphnites (aquoso) e Bauhinia rufa (etanólico), ambos foram ativos apenas contra uma espécie, Candida glabrata (24 e $25 \mathrm{~mm})$.

Estes resultados revelaram que, em geral, Candida glabrata foi a espécie mais sensível, seguido por Candida parapsilosis, e Candida albicans que foi a espécie mais resistente, pois não foi inibida por nenhum dos extratos testados. O controle positivo, fluconazol $(25 \mu \mathrm{g})$ e os controles negativos (água e etanol 95\%) confirmaram o desempenho do método e contribuíram na interpretação correta dos resultados (Tabela 16).

Tabela 16 - Atividade antifúngica dos extratos brutos sobre cepas padrões ATCC pelo método de Disco Difusão

\begin{tabular}{|c|c|c|c|c|c|c|c|c|c|c|c|c|c|}
\hline \multirow[b]{3}{*}{ ATCC } & \multicolumn{13}{|c|}{ Diâmetro de Inibição } \\
\hline & \multicolumn{6}{|c|}{ Extrato aquosos } & \multicolumn{7}{|c|}{ Extrato etanólico } \\
\hline & 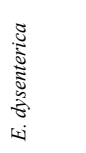 & 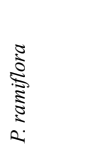 & 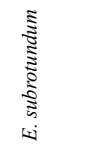 & 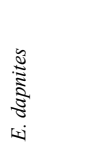 & $\frac{\sqrt{2}}{2}$ & 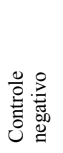 & 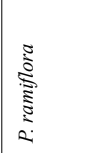 & $\begin{array}{l}\frac{3}{3} \\
\stackrel{3}{2} \\
0\end{array}$ & 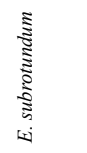 & 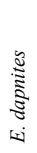 & $\underset{\substack{5 \\
\infty}}{\infty}$ & 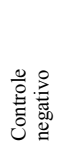 & 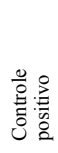 \\
\hline C.glabrata (2001) & - & $20 \pm 0,0$ & $30 \pm 0,0$ & $24 \pm 0,0$ & $25 \pm 0,0$ & - & $23 \pm 0,0$ & $15 \pm 0,0$ & $20 \pm 0,0$ & - & $25 \pm 0,0$ & - & 40 \\
\hline C. parapsilosis (22019) & $15 \pm 0,0$ & - & $11 \pm 1,1$ & - & $10 \pm 0,0$ & - & - & $10 \pm 0,0$ & $10 \pm 0,0$ & - & - & - & 33 \\
\hline C. guilliermondii (6260) & $12 \pm 0,0$ & - & $10 \pm 0,0$ & - & - & - & - & $10 \pm 0,0$ & - & - & - & - & 50 \\
\hline C.tropicalis (28707) & $12 \pm 0,0$ & $12 \pm 0,0$ & - & - & - & - & $13 \pm 2,8$ & - & - & - & - & - & 30 \\
\hline C. krusei (34135) & $13 \pm 0,0$ & - & - & - & - & - & $10 \pm 0,0$ & - & - & - & - & - & 18 \\
\hline C.famata (62894) & $12 \pm 0,0$ & - & - & - & - & - & - & - & - & - & - & - & 35 \\
\hline C.albicans (90028) & - & - & - & - & - & - & - & - & - & - & - & - & 39 \\
\hline
\end{tabular}

(-) Ausência de atividade antifúngica 
Para os extratos selecionados, foram determinadas as concentrações inibitórias mínimas (CIM), com o objetivo de confirmar a atividade antifúngica e verificar a potência contra as cepas testadas. O extrato aquoso de Eugenia dysenterica exibiu as menores CIM e

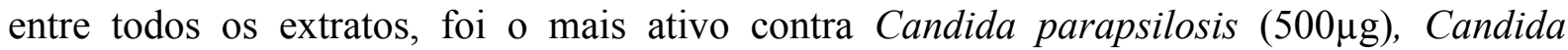
guilliermondii $(500 \mu \mathrm{g})$, Candida tropicalis $(125 \mu \mathrm{g})$, Candida krusei $(250 \mu \mathrm{g})$ e Candida famata $(125 \mu \mathrm{g})$. Os extratos de Pouteria ramiflora, aquoso e etanólico, ocupou o segundo lugar de efetividade antifúngica contra Candida tropicalis $(500 \mu)$ e os demais extratos demonstraram atividade contra as cepas de Candida spp. apenas na concentração inicial de

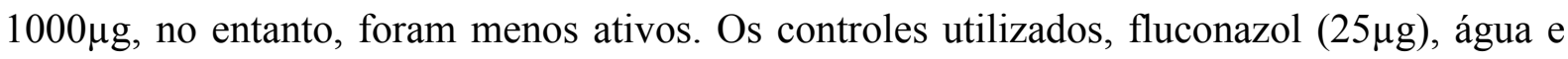
etanol 95\%, também confirmaram o desempenho do método e contribuíram na interpretação dos resultados (Tabela 17).

Tabela 17 - Concentrações inibitórias mínimas dos extratos brutos vegetais de plantas do cerrado brasileiro, contra cepas padrões ATCC de Candida spp.

\begin{tabular}{|c|c|c|c|c|c|c|c|c|c|c|c|}
\hline \multirow[b]{3}{*}{ Cepas ATCC } & \multirow[b]{3}{*}{ Origem } & \multicolumn{10}{|c|}{ CIM $(\mu \mathrm{g})$} \\
\hline & & \multicolumn{5}{|c|}{ Extratos aquosos } & \multicolumn{5}{|c|}{ Extratos etanólicos } \\
\hline & & 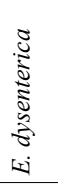 & 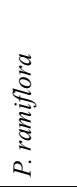 & 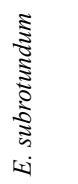 & 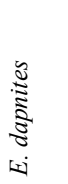 & $\frac{\sqrt[3]{0}}{\infty}$ & 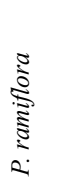 & $\begin{array}{l}\frac{0}{0} \\
\frac{0}{2} \\
0\end{array}$ & 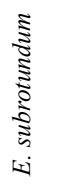 & 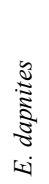 & $\frac{\sqrt{0}}{\infty}$ \\
\hline C. glabrata (2001) & Fezes & - & 1000 & 1000 & 1000 & 1000 & 1000 & 1000 & 1000 & - & 1000 \\
\hline C. parapsilosis (22019) & Fezes (diarréia crônica) & 500 & - & 1000 & - & 1000 & - & 1000 & 1000 & - & - \\
\hline C. guilliermondii (6260) & Saliva (broncomicose) & 500 & - & 1000 & - & - & - & 1000 & - & - & - \\
\hline C. tropicalis (28707) & Urina (pielonefrite) & 125 & 500 & - & - & - & 500 & - & - & - & - \\
\hline C. krusei (34135) & Espécime clínico & 250 & - & - & - & - & 1000 & - & - & - & - \\
\hline C. famata (62894) & Ponta de cateter & 125 & - & - & - & - & - & - & - & - & - \\
\hline C. albicans (90028) & Sangue & - & - & - & - & - & - & - & - & - & - \\
\hline
\end{tabular}

(-) Ausência de atividade antifúngica

Em seguida, os nove extratos com atividade antifúngica foram testados contra os 148 isolados clínicos de Candida spp. e contra o isolado clínico de Kodamaea ohmeri. Para isto, foram mantidas as concentrações iniciais dos extratos, $1000 \mu \mathrm{g}$ e também o padrão de interpretação da caracterização da atividade inibitória, formação de halo de inibição $\geqq 10 \mathrm{~mm}$ de diâmetro.

O extrato aquoso de Eugenia dysenterica foi ativo contra a maioria $(n=30)$ dos isolados clínicos de Candida parapsilosis (halo de inibição até $15 \mathrm{~mm}$ ), quatro isolados de 
Candida tropicalis (10 e 15mm) e os isolados de Candida guilliermondii (12mm) e Candida krusei (12mm). Embora não tenha apresentado atividade inibitória contra as cepas ATCC de Candida albicans e Candida glabrata, revelou halos de inibição de até $11 \mathrm{~mm}$ para os isolados de Candida albicans $(\mathrm{n}=7)$ e até $30 \mathrm{~mm}$ para grande parte dos isolados de Candida glabrata $(\mathrm{n}=10)$. Este extrato foi o único que inibiu o crescimento dos isolados de Candida intermedia (12mm) e Kodamaea ohmeri (12mm) (Figura 19).

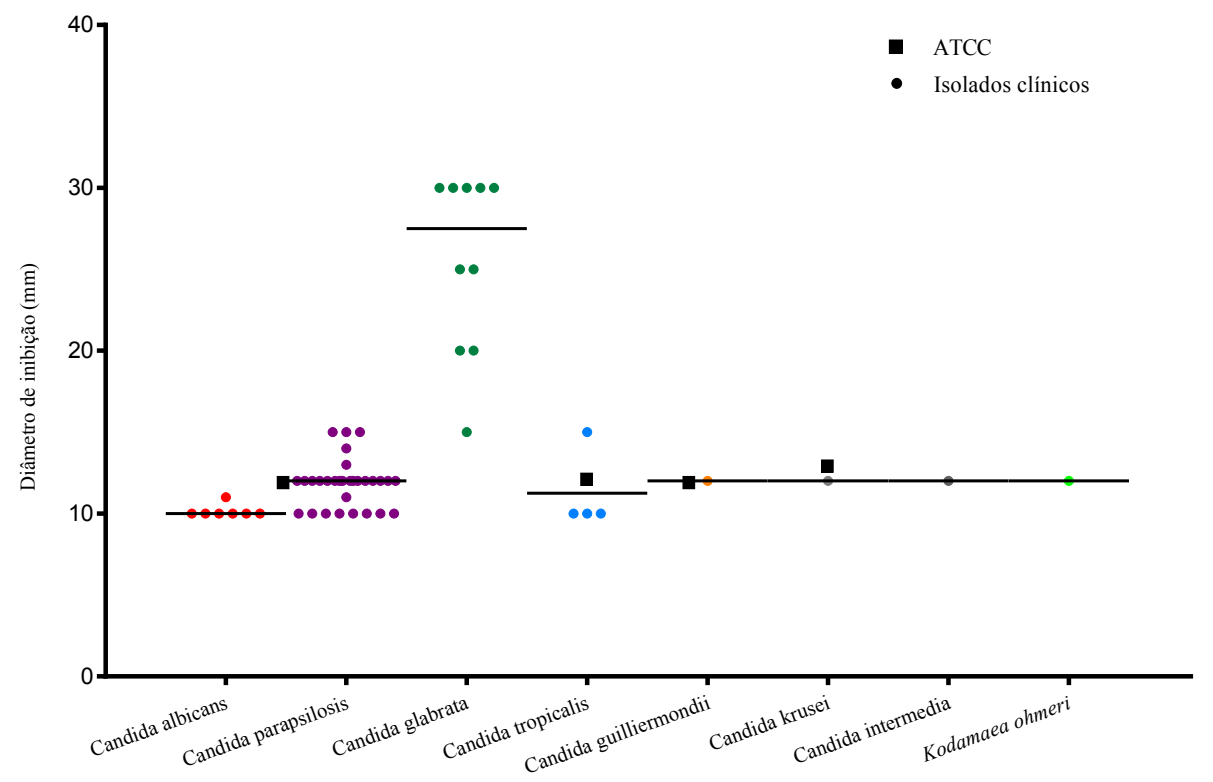

Figura 19 - Atividade antifúngica do extrato aquoso de Eugenia dysenterica

O extrato aquoso de Pouteria ramiflora, apesar de não apresentar atividade inibitória contra isolado clínico de Candida tropicalis, inibiu todos $(\mathrm{n}=12)$ os isolados de Candida glabrata (variação do halo de inibição 15 a 25mm). Além disso inibiu o crescimento de três isolados clínicos de Candida albicans $(13,15$ e 15mm) e dois isolados clínicos de Candida parapsilosis (11 e 11mm) (Figura 20). 


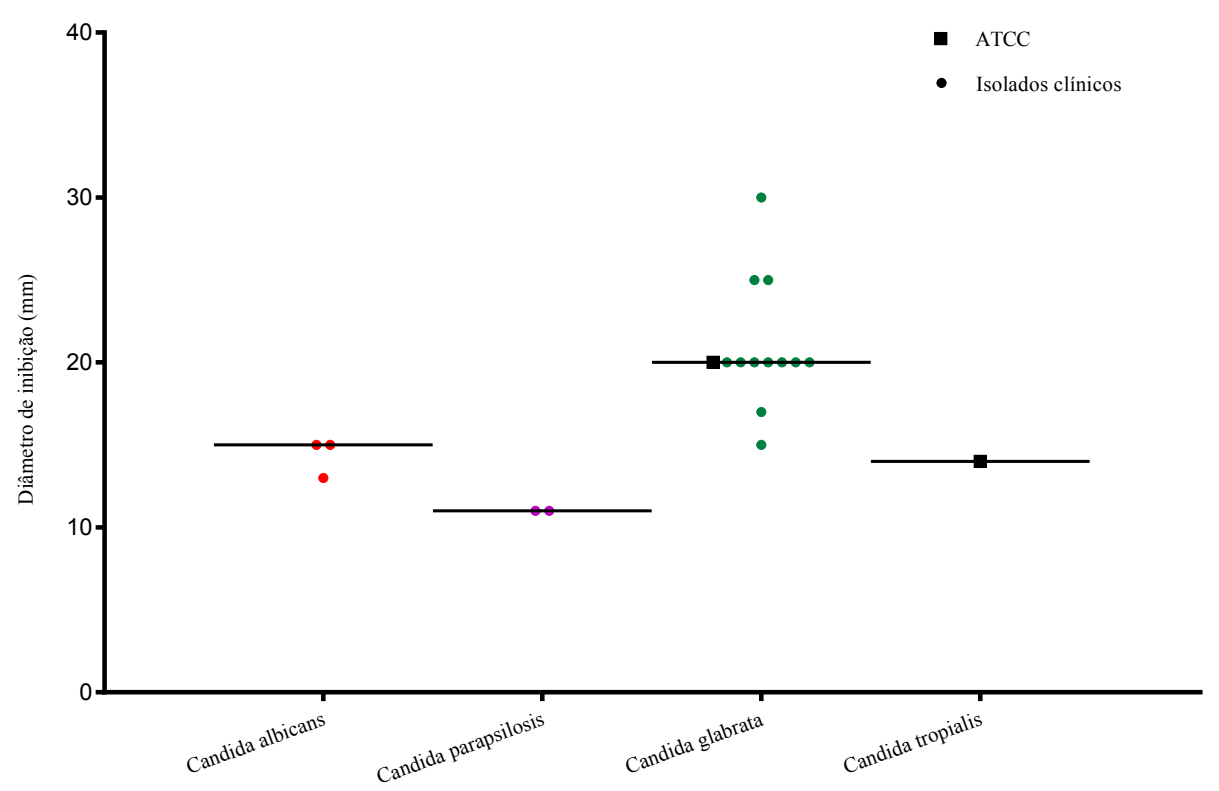

Figura 20 - Atividade antifúngica do extrato aquoso de Pouteria ramiflora

O extrato etanólico de Pouteria ramiflora, foi ativo contra todos os isolados de Candida glabrata (variação do halo de inibição 15 a 25mm), contra o isolado de Candida krusei $(10 \mathrm{~mm})$ e contra um isolado de Candida tropicalis $(10 \mathrm{~mm})$ e também exibiu atividade inibitória contra dois isolados de Candida albicans (10 e 10mm) (Figura 21).

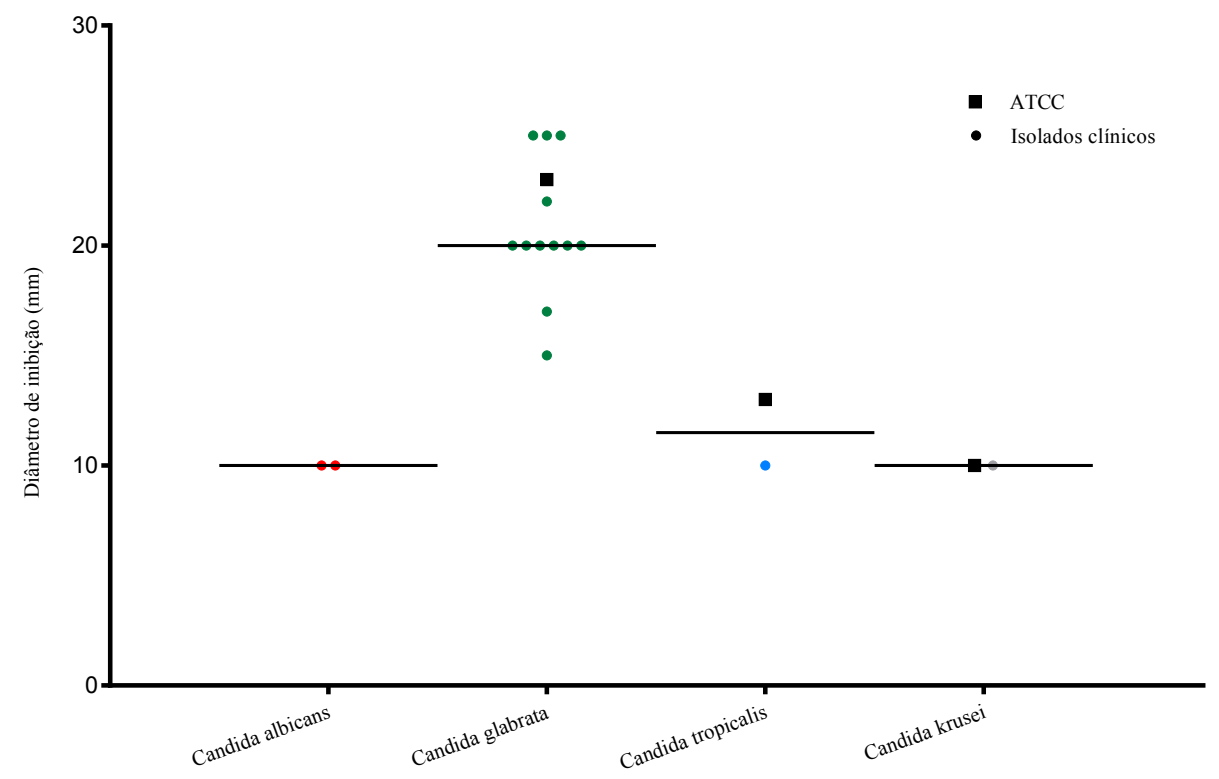

Figura 21 - Atividade antifúngica do extrato etanólico de Pouteria ramiflora 
O extrato etanólico de Pouteria torta, não inibiu isolados clínicos de Candida parapsilosis e Candida guilliermondii. Foi ativo contra todos os isolados de Candida glabrata (variação do halo de inibição 15 a $25 \mathrm{~mm}$ ) e revelou atividade antifúngica contra um isolado de Candida tropicalis (10mm) (Figura 22).

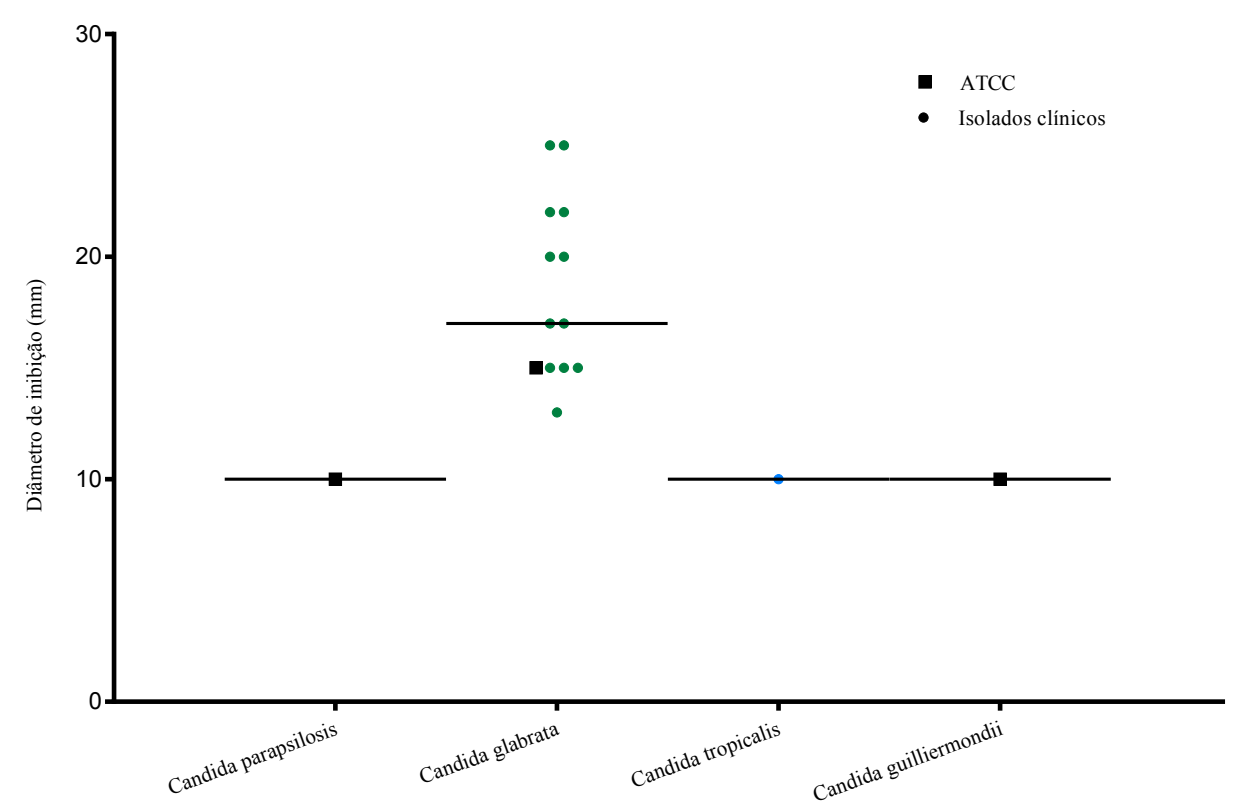

Figura 22 - Atividade antifúngica do extrato etanólico de Pouteria torta

O extrato aquoso de Erythroxylum subrotundum foi ativo contra todos $(\mathrm{n}=12)$ os isolados de Candida glabrata (variação do halo de inibição 20 a 30mm) e dois isolados de Candida parapsilosis (10 e 10mm). Não foi ativo contra Candida guilliermondii e revelou atividade inibitória contra um isolado de Candida tropicalis (10mm) (Figura 23). 


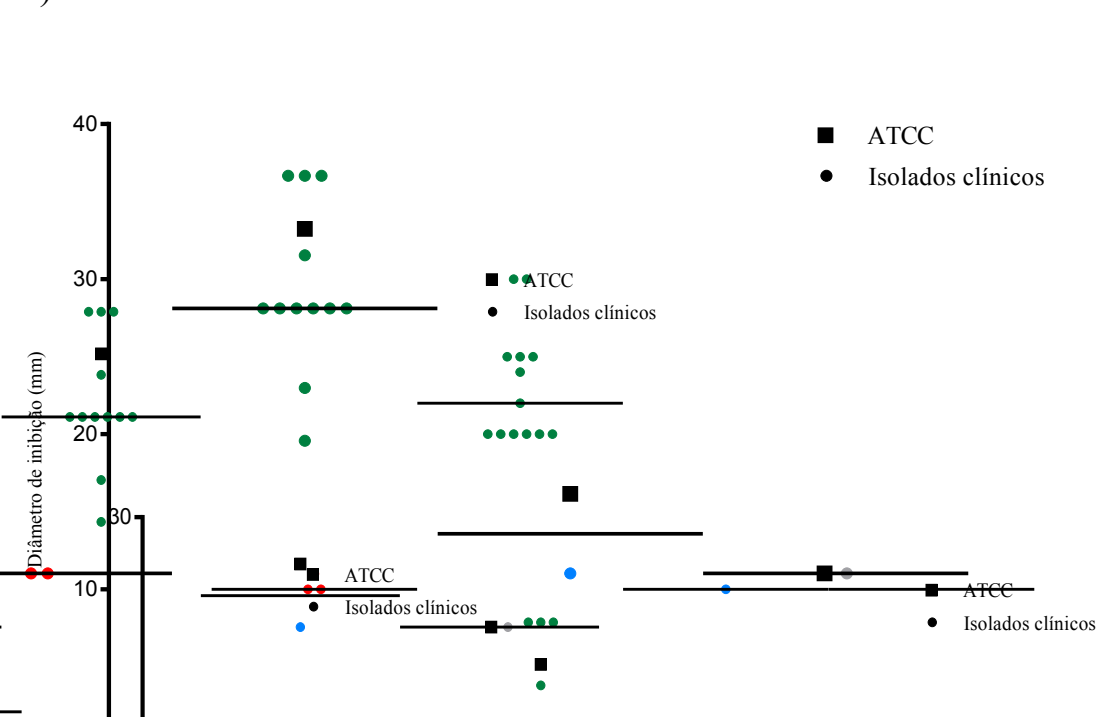

Figura 23 - Atividade antifúngica do extrato aquoso de Erythroxylum subrotundum

O extrato etanólico de Erythroxylum subrotundum e o extrato aquoso de Bauhinia rufa, ambos foram ativos contra as cepas ATCC de Candida glabrata e Candida parapsilosis. No entando, contra os isolados clínicos nenhum inibiu o crescimento dos isolados de Candida parapsilosis, porém inibiram o crescimento de todos os isolados de Candida glabrata $(\mathrm{n}=12)$, com variação do halo de inibição de 15 a $25 \mathrm{~mm}$ para o extrato etanólico de Erythroxylum subrotundum e 14 a 25mm para o extrato aquoso de Bauhinia rufa (Figuras 24 e 25).

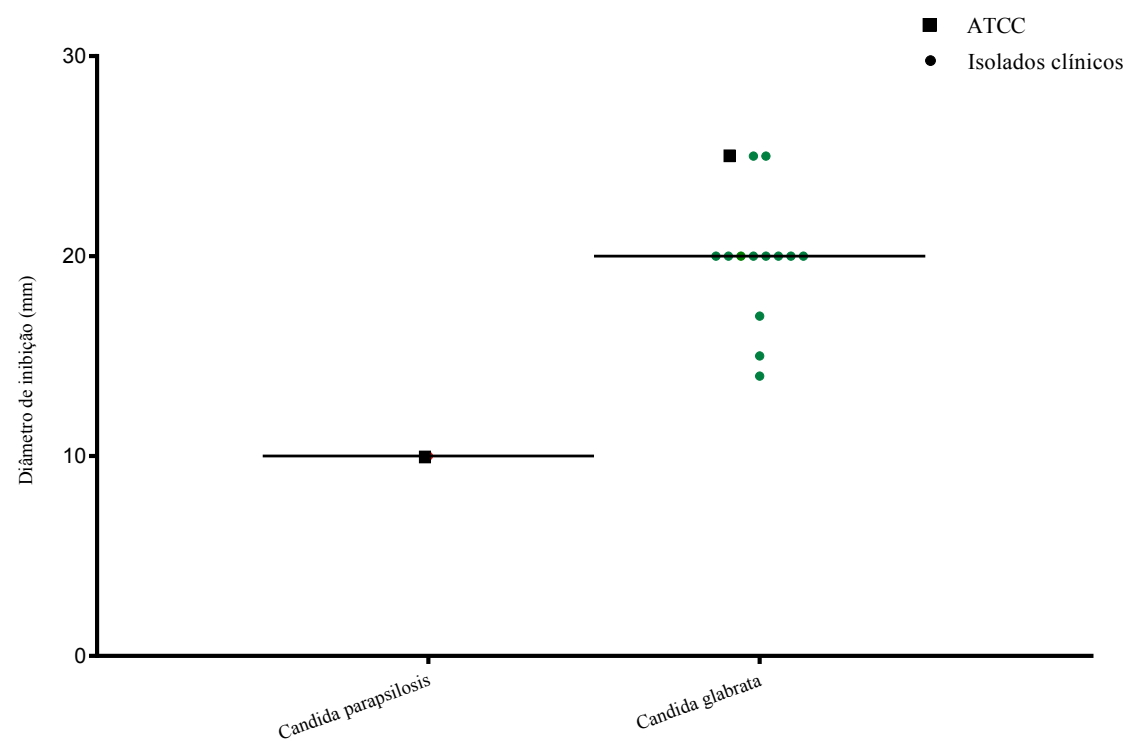

Figura 24 - Atividade antifúngica do extrato aquoso de Bauhinia rufa 


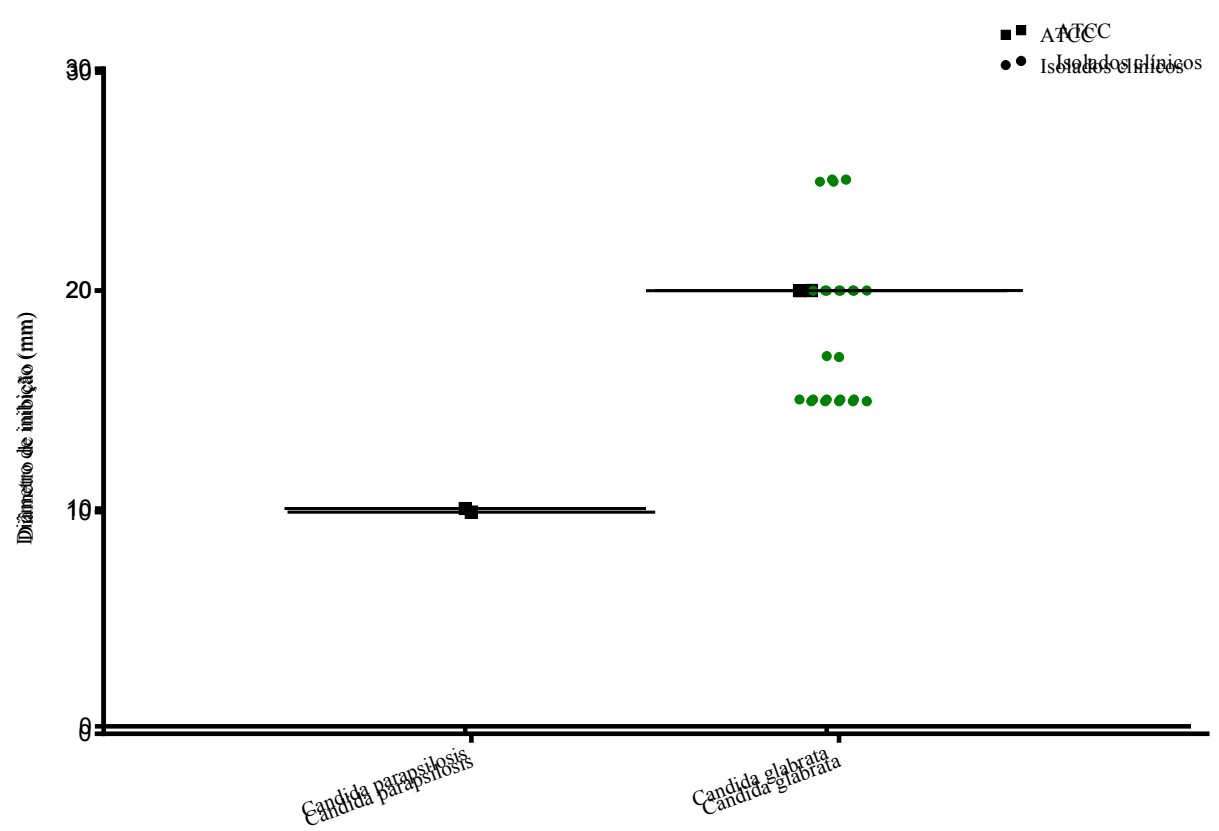

Figura 25 - Atividade antifúngica do extrato etanólico de Erythroxylum subrotundum

O extrato etanólico de Bauhinia rufa e o extrato aquoso de Erythroxylum daphnites monstraram atividade contra os isolados clínicos de Candida glabrata. O extrato etanólico de Bauhinia rufa inibiu todos os isolados, com variação do halo de inibição de 17 a $25 \mathrm{~mm}$ e o extrato aquoso de Erythroxylum daphnites inibiu 10 de 12 isolados de Candida glabrata e apresentou variação de halo de inibição de 15 a 25 mm (Figura 26 e 27).

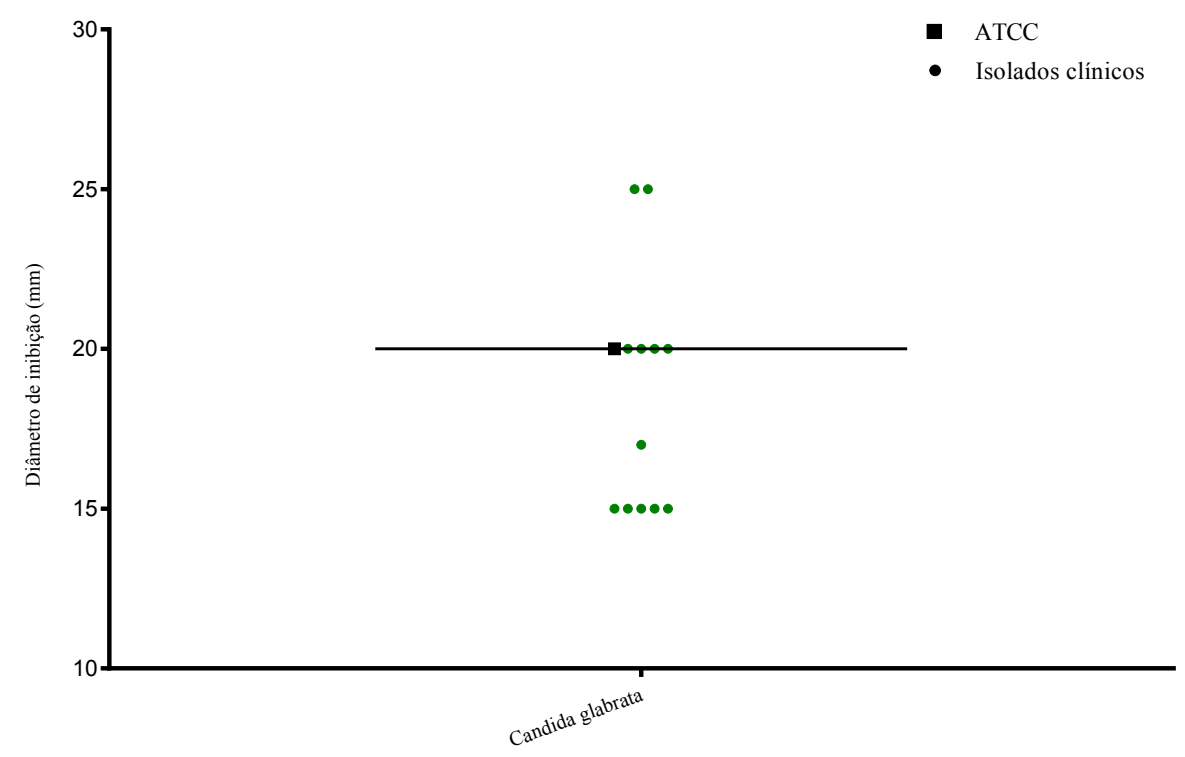

Figura 26 - Atividade antifúngica do extrato etanólico de Bauhinia rufa 


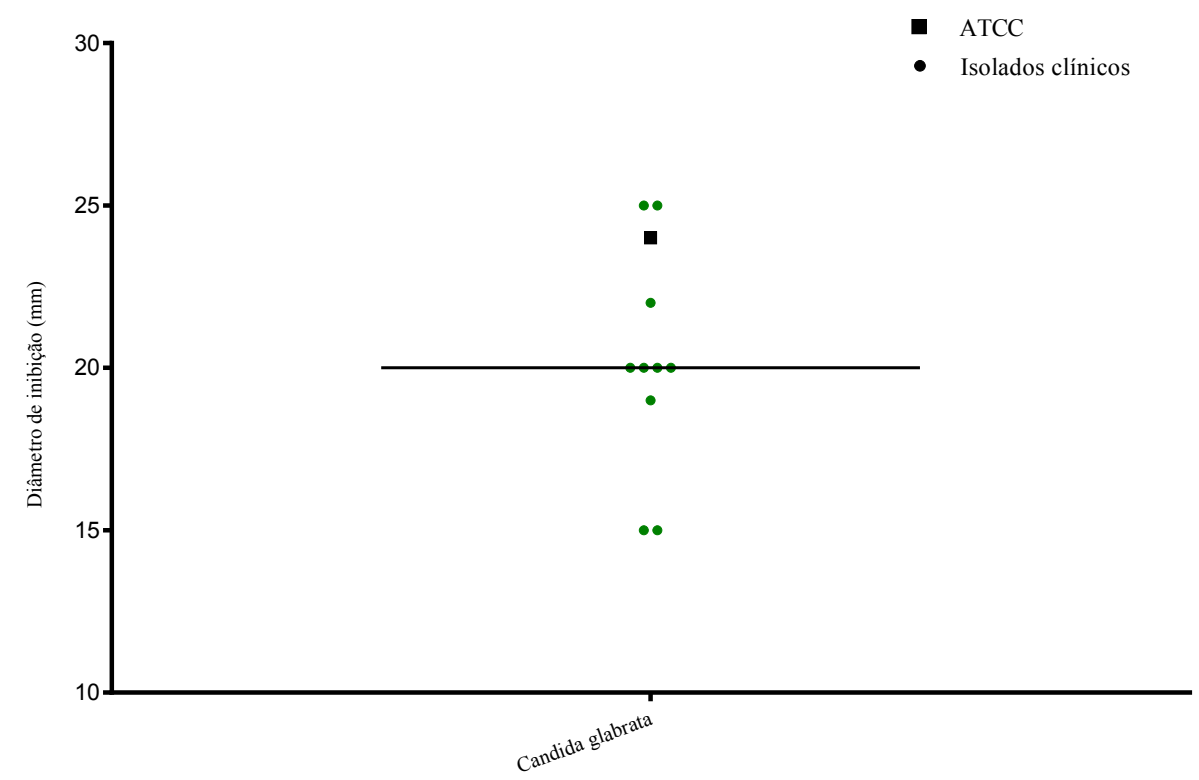

Figura 27 - Atividade antifúngica do extrato aquoso de Erythroxylum daphnites

O resultado final da atividade antifúngica dos extratos ativos estão representados na Tabela 18 .

Tabela 18 - Atividade antifúngica dos extratos brutos vegetais

\begin{tabular}{l|l|l}
\hline Extratos brutos vegetais & Extratos & Espécies fúngicas inibidas \\
\hline Eugenia dysenterica & A & Calb, Cpar, Ctro, Cgla, Cgui, Ckru, Cint, Kohm \\
Pouteria ramiflora & A & Calb, Cpar, Ctro, Cgla \\
Pouteria torta & E & Calb, Ctro, Cgla, Ckru \\
Bauhinia rufa & E & Cpar, Ctro, Cgla, Cgui \\
Erythroxylum subrotundum & A & Cpar, Cgla \\
& E & Cgla \\
Erythroxylum daphnites & A & Cpar, Ctro, Cgla, Cgui \\
\hline
\end{tabular}

Candida albicans (Calb), Candida parapsilosis (Cpar), Candida glabrata (Cgla), Candida tropicalis (Ctro), Candida krusei (Ckru), Candida guilliermondii (Cgui), Candida intermedia (Clus) e Kodamaea ohmeri (Kohm)

Nossos resultados mostraram que nove dos dez extratos de plantas testados apresentaram atividade sobre pelo menos uma das espécies de Candida spp. e o extrato de Eugenia dysenterica foi o extrato que apresentou efeito inibitório sobre todas as espécies de Candida. Após avaliar a atividade biológica destes extratos brutos de plantas e considerar que há existência de variações no perfil de sensibilidade destas espécies de leveduras frente aos limitados agentes antifúngicos convencionais disponíveis, passamos a refletir sobre a importância dos fitocomplexos presentes nestes extratos e no grande potencial que pode advir 
deles para o desenvolvimentos de novos antifúngicos com espectro de ação possivelmente mais amplo que os fármacos convencionais.

Os fitocomplexos são substâncias originadas no metabolismo primário ou secundário, ou mesmo ambos, dos extratos das plantas, responsáveis em conjunto, pelos efeitos biológicos de uma planta medicinal ou de seus derivados (RDC 14, ANVISA). As atividades biológicas dos extratos podem ser justificadas pela presença destes compostos ativos, que agem sigergicamente e conferir efeitos diretos e indiretos. $\mathrm{O}$ efeito direto está relacionado a sua ação farmacológica, enquanto o indireto está associado a interações simultâneas com outras plantas ou fármacos (MARTINS et al., 2015).

Além disso, é importante destacar que o fato de uma planta de determinado gênero conter compostos químicos específicos e com valor medicinal, não significa que todas as outras espécies de plantas do mesmo gênero têm o mesmo valor (MARTINS et al., 2015). Como foi visto em nosso estudo, entre os extratos de Pouteria torta e Pouteria ramiflora e entre Erythroxylum subrotundum e Erythroxylum daphnites, houve inibição de espécies diferentes de Candida. Outros estudos também monstram que plantas da mesma espécie, com diferentes origens, podem ter consideravéis diferenças na composição química e possivelmente diferentes eficácia e potência em sua bioatividade (PIRBALOUTI; HASHEMI; GHAHFAROKHI, 2013; FARHAT et.al., 2013).

Sabendo do comportamento de espécies de Candida frente aos antifúngicos disponíveis para terapia, observamos uma mudança no perfil de sensibilidade com relativa alteração de prevalência de Candida albicans por espécies não albicans a exemplo do que ocorre com Candida glabrata multiressistente. Como resultado, os tratamentos convencionais são realizados cada vez mais com dose maiores para resolver as infecções, provocando diversos efeitos tóxicos e aumentando o nível de resistência. Outro achado importante nos nossos resultados foi a atividade de todos os extratos contra espécies de Candida glabrata, cujo perfil apresentava resistência cruzada aos azólicos.

Nossos dados, embora promissores, suscitam a necessidade de mais estudos, não apenas para avaliar o potencial antifúngico das plantas em estudo, mas também para estabelecer claramente mecanismos de ação envolvendo os compostos químicos presentes nos extratos das plantas que apresentaram atividade contra as espécies de Candida, assim como 
validar os resultados em estudos in vivo visando possível aplicabilidade tanto como fitoterápicos, como fonte de desenvolvimento de novos agentes antifúngicos. 


\section{CONCLUSÃO}

São necessárias combinações entre métodos clássicos e também a realização de provas complementares para a identificação fenotípica de Candida spp.

Os métodos moleculares disponíveis confirmam que o uso de métodos não moleculares para o diagnóstico clínico deve ser cauteloso, pois possuem baixa acurácia tanto na determinação de espécies de Candida comumente associadas a candidíase sistêmica como na identificação de novas espécies.

Entre os métodos moleculares, PCR RFLP apresentou 94,7\% de especificidade, padrão ouro neste estudo, e o MALDI TOF apresentou concordância de $84,2 \%$ com a técnica de PCR RFLP além disso, permitiu a identificação de outras espécies como Kodamaea ohmeri.

Candida albicans foi a espécie mais prevalente no Distrito Federal, entre Janeiro de 2011 a Dezembro de 2012. Seguida de outras espécies não albicans, Candida parapsilosis, Candida tropicalis, Candida glabrata, Candida krusei, Candida guilliermondii, Candida intermedia e um isolado misto constituido de Candida albicans e Candida glabrata, ressaltando a importância do estudo de prevalência de espécies de Candida não albicans que não são detectadas rotineiramente nos laboratórios clínicos

Embora a maioria dos isolados clínicos tenha monstrado susceptibilidade a anfotericia B (97,9\%), voriconazol (91,9\%), fluconazol (91,3\%) e itraconazol (67\%). 97,3\% dos isolados exibiram susceptibilidade reduzida à 5-fluorocitocina.

Foram detectadas espécies com resistência cruzada aos azólicos como Candida glabrata. Estes achados corroboram resultados encontrados em programas de vigilâncias mundiais, onde a resistência cruzada aos azólicos é cada vez mais comum e representa sério problema de saúde pública. 
Extratos das plantas do cerrado, Eugenia dysenterica, Pouteria ramiflora, Pouteria torta, Erythroxylum subrotundum, Erythroxylum daphnites e Bauhinia rufa possuem fitocompostos com potenciais atividades antifúngicas contra espécies de Candida, principalmente espécies de Candida não albicans, que representam atualmente grande revelância clínica e terapêutica.

A atividade do extrato aquoso das folhas de Eugenia dysenterica se destaca em relação aos outros extratos, pois além de apresentar efeitos inibitórios em menores concentrações monstrou o melhor espectro de ação, ao inibir todas as espécies de leveduras isoladas.

Os noves extratos que apresentaram atividade antifúngica contra Candida glabrata devem ser investigados, com a perspectiva de isolar ou caracterizar compostos bioativos que justifiquem o efeito antifúngico inibitório contra estas espécies de leveduras, bem como descrever seus possíveis mecanismos de ação e sua atividade in vivo. 


\section{REFERÊNCIAS}

ALEXANDER, B. D. et al. Increasing echinocandin resistance in Candida glabrata: clinical failure correlates with presence of FKS mutations and elevated minimum inhibitory concentrations. Clinical Infectious Diseases, v. 56, n. 12, p. 1724-1732, 2013.

ALVES, T. M. et al. Biological screening of Brazilian medicinal plants. Memórias do Instituto Oswaldo Cruz, v. 95, n. 3, p. 367-373, 2000.

ALVES-ARAUJO, A.; SWENSON, U.; ALVES, M. A. Taxonomic Survey of Pouteria (Sapotaceae) from the Northern Portion of the AtClinical Microbiology Reviews lantic Rainforest of Brazil. Systematic Botany, v. 39, n. 3, p. 915-938, 2014.

ANDERSON, J.B. Evolution of antifungal drug resistance: Mechanisms and pathogen fitness. Nature, v. 3, n. 7, p. 545-556, 2005.

ARVANITIS, M. et al. Molecular and nonmolecular diagnostic methods for invasive fungal infections. Clinical Microbiology Reviews, v. 27, n. 3, p. 490-526, 2014.

ASSOB, J. N. et al. Antimicrobial and toxicological activities of five medicinal plant species from Cameroon traditional medicine. BMC Complementary and Alternative Medicine, v. 11, n. 70, p. 1-27, 2011.

BAGINSKI, M.; CZUB, J. Amphotericin B and Its New Derivatives - Mode of Action. Current Drug Metabolism, v.10, n. 5, p. 459-469, 2009.

BANKOLE, M. A. et al. Synergistic antimicrobial activities of phytoestrogens in crude extracts of two sesame species against some common pathogenic microorganisms. African Journal of Traditional, Complementary and Alternative Medicines, v. 4, n. 4, p. 427-433, 2007.

BARBOSA, A. et al. Range-wide genetic differentiation of Eugenia dysenterica (Myrtaceae) populations in Brazilian Cerrado. Biochemical Systematics and Ecology, v. 59, p. 288-296, 2015.

BIERI, S. et al. Cocaine distribution in wild Erythroxylum species. Journal of Ethnopharmacology, v. 103, n. 3, p. 439-447, 2006.

BOHM, B. et al. Flavonoid variation in Erytrhoxylum. Phytochemistry, v. 27, n. 3, p. 833-837, 1988.

BRASIL. Dispõe sobre o REGISTRO DE MEDICAMENTOS FITOTÉRAPICOS E O REGISTRO E A NOTIFICAÇÃO DE PRODUTOS TRADICIONAIS FITOTERÁPICOS. RDC $n^{\circ} 26$ (13 de Maio de 2014). D.O.U. Brasília: Anvisa p. 34, 2014. 
BROCK, A. et al. Calystegines in wild and cultivated Erythroxylum species. Phytochemistry, v. 66, n. 11, p. 1231-1240, 2005.

CARVALHO, A. et al. Multiplex PCR identification of eight clinically relevant Candida species. Medical Mycology, v. 45, n. 7, p. 619-627, 2007.

CECÍLIO, A. B. et al. Screening of Brazilian medicinal plants for antiviral activity against rotavirus. Journal of Ethnopharmacology, v. 141, n. 3, p. 975-981, 2012.

CHANDER, J. Emergence of Antifungal Resistance and Resistant Candida Species in Healthcare Setups. Journal of Patient Safety \& Infection Control, v.1, n.1, p. 22-24, 2013.

CHANG, T. P. et al. Distribution and drug susceptibilities of Candida species causing candidemia from a medical center in central Taiwan. Journal of Infection and Chemotherapy, v. 19, n. 6, p. 1065-1071, 2013.

CLSI. Method for Antifungal Disk Diffusion Susceptibility Testing of Yeasts: Approved Guideline. Waine, Pensilvânia - USA, 2004.

Zone Diameter Interpretive Standards, Corresponding Minimal Inhibitory Concentration (mic) Interpretive Breakpoints, And Quality Control Limits For Antifungal Disk Diffusion Susceptibility Testing Of Yeasts. Waine, Pensilvânia - USA, 2007.

COLOMBO, A. L. et al. Brazilian guidelines for the management of candidiasis - a joint meeting report of three medical societies: Sociedade Brasileira de Infectologia, Sociedade Paulista de Infectologia and Sociedade Brasileira de Medicina Tropical. Brasilian Journal of Infectious Diseases, v. 17, n. 3, p. 283-312, 2013.

COLOMBO, A. L. et al. Epidemiology of candidemia in Brazil: a nationwide sentinel surveillance of candidemia in eleven medical centers. Journal of Clinical Microbiology, v. 44, n. 8, p. 2816-2823, 2006.

CORNISTEIN, W. et al. Candida: epidemiología y factores de riesgo para especies no albicans. Enfermedades Infecciosas y Microbiología Clínica, v. 31, n. 6, p. 380-384, 2013.

CORONADO-CASTELLOTE, L.; JIMÉNEZ-SORIANO, Y. Clinical and microbiological diagnosis of oral candidiasis. Journal of Clinical and Experimental Dentistry, v. 5, n. 5, p. 279-286, 2013.

COSTA, T. R. et al. Antifungal activity of volatile constituents of Eugenia dysenterica leaf oil. Journal of Ethnopharmacology, v. 72, n. 1-2, p. 111-117, 2000.

COSTA-DE-OLIVEIRA, S. et al. Determination of chitin content in fungal cell wall: an alternative flow cytometric method. Cytometry Part A, v. 83, n. 3, p. 324-328, 2013. 
CRISEO, G.; SCORDINO, F.; ROMEO, O. Current methods for identifying clinically important cryptic Candida species. Journal of Microbiological Methods, v. 111, p. 50-56, 2015.

CÁRDENES, C. D. et al. Comparison of Albicans ID2 agar plate with the germ tube for presumptive identification of Candida albicans. Diagnostic Microbiology and Infectious Disease, v. 42, n. 3, p. 181-185, 2002.

COSTA, A. V. et al. Neuroprotective effects of Pouteria ramiflora (Mart.) Radlk (Sapotaceae) extract on the brains of rats with streptozotocin-induced diabetes. Metabolic Brain Disease, v. 28, n. 3, p. 411-419, 2013.

COSTA et al. Nosocomial bloodstream Candida infections in a tertiary-care hospital in South Brazil: a 4-year survey. Mycopathologia, v. 178, n. 3-4, p. 243-250, 2014 b.

DE GROOT, P. W. et al. The cell wall of the human pathogen Candida glabrata: differential incorporation of novel adhesin-like wall proteins. Eukaryotic Cell, v. 7, n. 11, p. 1951-64, 2008.

DRELL, T. et al. Characterization of the vaginal micro- and mycobiome in asymptomatic reproductive-age Estonian women. PLoS One, v. 8, n. 1, p. 1-11, 2013.

DUARTE, A. et al. Genetic and Environmental Influence on Essential Oil Composition of Eugenia dysenterica Journal of the Brazilian Chemical Society, v. 21, n. 8, p. 1459-1467, 2010.

DUARTE-ALMEIDA, J.; NEGRI, G.; SALATINA, A. Volatile oils in leaves of Bauhinia (Fabaceae Caesalpinioideae). Biochemical Systematics and Ecology, v. 32, p. 747-753, 2004

EGGIMANN, P. et al. Preventing invasive Candida infections. Where could we do better? Journal of Hospital Infection, v. 89, n. 4, p. 302-308, 2015.

ELIAS, S. T. et al. Radiation induced a supra-additive cytotoxic effect in head and neck carcinoma cell lines when combined with plant extracts from Brazilian Cerrado biome. Clinical Oral Investigations, v. 19, n. 3, p. 637-646, $2015 \mathrm{a}$.

ESTRADA-BARRAZA, D. et al. Comparación entre métodos convencionales, ChromAgar Candida ${ }^{\circledR}$ y el método de la PCR para la identificación de especies de Candida en aislamientos clínicos. Revista Iberoamericana de Micología, v. 28, n. 1, p. 36-42, 2011.

FERRARA, G. et al. Estudio comparativo entre los sistemas automatizados Vitek YBC[R] y Microscan Walk Away RYID[R] con los métodos fenotípicos convencionales para la identificación de levaduras de intéres clínico. Investigación Clínica, v. 55, n. 4, p. 297-310, 2014. 
FIGUEIREDO, S. M. et al. Cerebral macroabscess caused by Candida albicans in an immunocompetent patient: A diagnostic challenge. Medical Mycology Case Reports, v. 3, p. 17-19, 2014.

FINDLEY, K. et al. Topographic diversity of fungal and bacterial communities in human skin. Nature, v. 498, n. 7454, p. 367-370, 2013.

FLEVARI, A. et al. Treatment of invasive candidiasis in the elderly: a review. Journal of Clinical Interventions in Aging, v. 8, p. 1199-1208, 2013.

FURLETTI, V. F. et al. Action of Coriandrum sativum L. Essential Oil upon Oral Candida albicans Biofilm Formation. Evidence-Based Complementary and Alternative Medicine, v. 2011, p. 1-9, 2011.

GHANNOUM, M. A. et al. Characterization of the oral fungal microbiome (mycobiome) in healthy individuals. PLoS Pathogens, v. 6, n. 1, p. 1-8, 2010.

GHANNOUM, M. A.; RICE, L. B. Antifungal agents: mode of action, mechanisms of resistance, and correlation of these mechanisms with bacterial resistance. Clinical Microbiology Reviews, v. 12, n. 4, p. 501-517, 1999.

GOUVEIA, N. M. et al. Pouteria ramiflora extract inhibits salivary amylolytic activity and decreases glycemic level in mice. Anais da Academia Brasileira de Ciências, v. 85, n. 3, p. 1141-1148, 2013.

GOW, N. A. et al. Candida albicans morphogenesis and host defence: discriminating invasion from colonization. Nature Reviews Microbiology, v. 10, n. 2, p. 112-122, 2012.

HAJDU, Z.; HOHMANN, J. An ethnopharmacological survey of the traditional medicine utilized in the community of Porvenir, Bajo Paraguá Indian Reservation, Bolivia. Journal of Ethnopharmacology, v. 139, n. 3, p. 838-857, 2012.

HOFFMANN, C. et al. Archaea and fungi of the human gut microbiome: correlations with diet and bacterial residents. PLoS One, v. 8, n. 6, p. 1-12, 2013.

HOOG, G. D. et al. Atlas of Clinical Fungi. 2. Washington, DC: PRESS, 2001. 1160p.

HOYER, L. L. The ALS gene family of Candida albicans. Trends in Microbiology, v. 9, n. 4, p. 176-180, 2001.

HUANG, G. Regulation of phenotypic transitions in the fungal pathogen Candida albicans. Virulence, v. 3, n. 3, p. 251-261, 2012.

ILIEV, I. D.; UNDERHILL, D. M. Striking a balance: fungal commensalism versus pathogenesis. Current Opinion in Microbiology, v. 16, n. 3, p. 366-373, 2013. 
JOHANN, S. et al. Antifungal properties of plants used in Brazilian traditional medicine against clinically relevant fungal pathogens. Brazilian Journal of Microbiology, v. 38, p. 632-637, 2007.

KALKANCI, A. et al. Epidemiology and antifungal susceptibility of Candida species isolated from hospitalized patients. Journal of Mecial Mycology, v. 17, n. 1, p. 16-20, 2007.

KATHIRAVAN, M. K. et al. The biology and chemistry of antifungal agents: a review. Bioorganic \& Medicinal Chemistry, v. 20, n. 19, p. 5678-5698, 2012.

KIM, S. H. et al. Misidentification of Candida guilliermondii as Candida famata among strains isolated from blood cultures by the VITEK 2 system. BioMed Research International, v. 2014, p. 1-6, 2014.

KLINK, C.A. MACHADO, R.B. A conservação do Cerrado brasileiro. Megadiversidade, v. 1, n. 1, p. 146-155, 2005.

KONEMAN, E. W. et al. Diagnóstico Microbiologico - Texto e Atlas Colorido. 5. Rio de Janeiro: MEDSI, 2001. 1465p.

LACAZ, C. S. et al. Guia para identificação fungos actinomicetos algas de interesse médico. São Paulo: SARVIER, 1998. 445p.

LARONE, D. H. Medically Important Fungi: a Guide to Identification. 3. Washington: ASM PRESS, 1995. 136p.

LEMAR, K. M. et al. Allyl alcohol and garlic (Allium sativum) extract produce oxidative stress in Candida albicans. Microbiology, v. 151, n. 10, p. 3257-3265, 2005.

LIMA, T. B. et al. In Vivo Effects of Cagaita (Eugenia dysenterica, DC) Leaf Extracts on Diarrhea Treatment. Evidence-Based Complementary and Alternative Medicine, v. 2011, p. 1-10, 2011.

LOCKHART, S. R. Current Epidemiology of Candida Infection. Clinical Microbiology Newsletter, v. 36, n. 17, p. 131-136, 2014.

LOIOLA, M. et al. Flora da Paraiba, Brasil: Erythroxylaceae Kunth. Acta. Botanica Brasilica, v. 21, n. 2, p. 473-487, 2007.

LORENZI, H. Arvores Brasileiras: manual de identificação e cultivo de plantas arbóreas nativas do Brasil. 2. Sao Paulo: EDITORA UFV, 2002. 368p.

LOW, C. F. et al. Inhibition of hyphae formation and SIR2 expression in Candida albicans treated with fresh Allium sativum (garlic) extract. Journal of Applied Microbiology, v. 105, n. 6, p. 2169-2177, 2008. 
MAGALHÃES, Y. C. et al. Clinical significance of the isolation of Candida species from hospitalized patients. Brazilian Journal of Microbiology, v. 46, n. 1, p. 117-123, 2015.

MARTINS N, B. L., HENRIQUES M, SILVA S. Activity of phenolic compounds from plant origin against Candida. Industrial Crops and Products, v. 74, p. 648-670, 2015.

MAYR, A.; LASS-FLORL.C. Non-Culture-Based Methods for the Diagnosis of Invasive Candidiasis. Current Fungal Infection Reports. v. 2011, n. 5, p. 151-156, 2011.

MCCARTY, T. P.; PAPPAS, P. G. Invasive Candidiasis. Infectious Disease Clinics of North America, 2015.

MENEZES, R. E. P. et al. FREQUENCY OF Candida SPECIES IN A TERTIARY CARE HOSPITAL IN TRIANGULO MINEIRO, MINAS GERAIS STATE, BRAZIL. Revista do Instituto de Medicina Tropical de Sao Paulo, v. 57, n. 3, p. 185-191, 2015.

MEZZARI, A.; FUENTEFrIA, A. M. Micologia no Laboratorio Clínico. 1. São Paulo: MANOLE, 2012.182p.

MILLAR, B. C. et al. A simple and sensitive method to extract bacterial, yeast and fungal DNA from blood culture material. Journal of Microbiological Methods, v. 42, n. 2, p. 139-147, 2000a.

MIRHENDI, H. et al. A one-enzyme PCR-RFLP assay for identification of six medically important Candida species. Nihon Ishinkin Gakkai Zasshi, v. 47, n. 3, p. 225-229, 2006.

MODRZEWSKA, B.; KURNATOWSKI, P. Selected pathogenic characteristics of fungi from the genus Candida. Annals of Parasitology, v. 59, n. 2, p. 57-66, 2013.

MORACE, G.; PERDONI, F.; BORGHI, E. Antifungal drug resistance in Candida species. Journal of Global Antimicrobial Resistance, v. 2, n. 4, p. 254-259, 2014.

NCC, S.; A, F. J. N. Biological properties of medicinal plants: a review of their antimicrobial activity. The Journal of Venomous Animals and Toxins including Tropical Diseases, v. 16, n. 3, p. 402-413, 2010.

NEPPELENBROEK, K. H. et al. Identification of Candida species in the clinical laboratory: a review of conventional, commercial, and molecular techniques. Oral Diseases, v. 20, n. 4, p. 329-44, 2014.

NEUFELD, P. M. Manual de micologia médica: técnicas básicas de diagnóstico. Rio de Janeiro: Programa Nacional de Controle de Qualidade, 1999. 230p.

NEUFELD, P. M. et al. Nosocomial candidiasis in Rio de Janeiro State: Distribution and fluconazole susceptibility profile. Brazilian Journal fo Microbiology, v. 46, n. 2, p. 477-484, 2015. 
NG, K. P. et al. Candida species epidemiology 2000-2013: a laboratory-based report. Tropical Medicine \& International Health, v. 20, n. 11, p. 1447-1453, 2015.

NGUYEN, L. D.; VISCOGLIOSI, E.; DELHAES, L. The lung mycobiome: an emerging field of the human respiratory microbiome. Frontiers in Microbiology, v. 6, p. 89, 2015.

NWEZE, E. I.; EZE, E. E. Justification for the use of Ocimum gratissimum L in herbal medicine and its interaction with disc antibiotics. BMC Complementary and Alternative Medicine, v. 9, p. 37, 2009.

ODDS, F. C.; BERNAERTS, R. CHROMagar Candida, a new differential isolation medium for presumptive identification of clinically important Candida species. Journal of Clinical Microbiology, v. 32, n. 8, p. 1923-1929, 1994.

OKSI, J. et al. Candida dubliniensis spondylodiscitis in an immunocompetent patient. Case report and review of the literature. Medical Mycology Case Reports, v. 3, p. 4-7, 2014.

PAPON, N. et al. Emerging and emerged pathogenic Candida species: beyond the Candida albicans paradigm. PLoS Pathogens, v. 9, n. 9, p. 1-4, 2013.

PAPPAS, P. G. Invasive candidiasis. Infectious Disease Clinics of North America, v. 20, n. 3, p. 485-506, 2006.

PATRICIO, M. C. B.; PIRANI, J. R. Flora da Serra do Cipó, Minas Gerais: Erythroxylaceae. Boletim de Botânica da Universidade de São Paulo, v. 20, p. 53-61, 2002.

PERFEITO, J. et al. Characterization and biological properties of Pouteria torta extracts: a preliminary study. Revista Brasileira de Farmacognosia, v. 15, n. 3, p. 183-186, 2005.

PFALLER, M. A. Antifungal drug resistance: mechanisms, epidemiology, and consequences for treatment. American Journal of Medicine, v. 125, n. 1 Suppl, p. S3-13, Jan 2012.

PFALLER, M. A. et al. Results from the ARTEMIS DISK Global Antifungal Surveillance Study, 1997 to 2007: a 10.5-Year Analysis of Susceptibilities of Candida Species to Fluconazole and Voriconazole as Determined by CLSI Standardized Disk Diffusion. Journal of Clinical Microbiology, v. 48, n. 4, p. 1366-1377, 2010.

PFALLER, M. A. et al. Isavuconazole, micafungin, and 8 comparator antifungal agents' susceptibility profiles for common and uncommon opportunistic fungi collected in 2013: temporal analysis of antifungal drug resistance using CLSI species-specific clinical breakpoints and proposed epidemiological cutoff values. Diagnostic Microbiology and Infectious Disease, v. 82, n. 4, p. 303-13, 2015. 
PIETRELLA, D. et al. Beneficial effect of Mentha suaveolens essential oil in the treatment of vaginal candidiasis assessed by real-time monitoring of infection. BMC Complementary and Alternative Medicine, v. 11, 2011.

PINCUS, D. H.; ORENGA, S.; CHATELLIER, S. Yeast identification--past, present, and future methods. Medical Mycology, v. 45, n. 2, p. 97-121, 2007.

PIRBALOUTI, A.; HASHEMI, M.; GHAHFAROKHI, F. Essential oil and chemical compositions of wild and cultivated Thymusdaenensis Celak and Thymus vulgaris L. Industrial Crops and Products, v. 48, p. 43-48, 2013.

PLOWMAN, T.; HENSOLD, N. Names, types, and distribution of neotropical species of Erythroxylum (Erythroxylaceae). Brittonia, v. 56, n. 1, p. 1-53, 2004.

PRADO, L. C. et al. The gastroprotective effects of Eugenia dysenterica (Myrtaceae) leaf extract: the possible role of condensed tannins. Medical Mycology, v. 37, n. 5, p. 722-730, 2014.

ROSSONI, R. D. et al. Competitive Interactions between Candida albicans, Candida glabrata and Candida krusei during Biofilm Formation and Development of Experimental Candidiasis. PLoS One, v. 10, n. 7, p. 1-23, 2015.

SANGUINETTI, M.; POSTERARO, B.; LASS-FLÖRL, Candida Antifungal drug resistance among Candida species: mechanisms and clinical impact. Mycoses, v. 58 Suppl 2, p. 2-13, 2015.

SATI, S. C; JOSHI, S. Aspects of Antifungal Potential of Ethonobotanically Known Medicinal Plants. Research Journal of Medicinal Plant, v. 5, n. 4, p. 377-391, 2011.

SIGMUNDSDÓTTIR, G. et al. Urine D-arabinitol/L-arabinitol ratio in diagnosis of invasive candidiasis in newborn infants. Journal of Clinical Microbiology, v. 38, n. 8, p. 3039-3042, 2000.

SILVA JUNIOR, I. E. et al. Antimicrobial screening of some medicinal plants from Mato Grosso Cerrado. Revista Brasileira de Farmacognosia, v. 19, n. 1b, p. 242-248, 2009.

SILVA, M. et al. Levantamento etnobotânico de plantas utilizadas comoanti-hiperlipidêmicas e anorexígenas pela população de Nova Xavantina-MT, Brasil. Revista Brasileira de Farmacognosia, v. 20, n. 4, p. 549-562, 2010.

SILVA, N. C; NERY, J. M.; DIAS, A. L. Aspartic proteinases of Candida spp.: role in pathogenicity and antifungal resistance. Mycoses, v. 57, n. 1, p. 1-11, 2014.

SILVA, R.; CHAVE, L.; NAVES, R. Caracterização de frutos e arvores de cagaita (Eugenia disenteria DC) no sudeste do estado de Goias, Brasil. Revista Brasileira de Fruticultura, v. 23, n. 2, p. 330-334, 2001. 
SIMÕES, C.M.O. et al. Farmacognosia da plantas ao medicamento. 6 ed. Florianópolis: EDITORA DA UFSC, 2007. 1102p.

SOLL, D. R. Candida commensalism and virulence: the evolution of phenotypic plasticity. Acta Tropica, v. 81, n. 2, p. 101-110, 2002.

SOUZA, P. M. et al. Plants from Brazilian Cerrado with Potent Tyrosinase Inhibitory Activity. Plos One, v. 7, n. 11, p. 1-7, 2012.

ST GERMAIN, G.; BEAUCHESNE, D. Evaluation of the MicroScan Rapid Yeast Identification panel. Journal of Clinical Microbiology, v. 29, n. 10, p. 2296-2299, 1991.

TAFF, H. T. et al. Mechanisms of Candida biofilm drug resistance. Future Microbiology, v. 8, n. 10, p. 1325-1337, 2013.

TAJ-ALDEEN, S. J.; DOIPHODE, S. H.; HAN, X. Y. Kodamaea (Pichia) ohmeri fungaemia in a premature neonate. Journal of Medical Microbiology, v. 55, n. 2, p. 237-239, 2006.

TAO, L. et al. Discovery of a "white-gray-opaque" tristable phenotypic switching system in Candida albicans: roles of non-genetic diversity in host adaptation. PLoS Biology, v. 12, n. 4, p. 1-14, 2014.

TASCHDJIAN, C. L.; BURCHALL, J. J.; KOZINN, P. J. Rapid identification of Candida albicans by filamentation on serum and serum substitutes. The American Journal of Diseases of Children, v. 99, p. 212-215, 1960.

THOMPSON, D. S.; CARLISLE, P. L.; KADOSH, D. Coevolution of morphology and virulence in Candida species. Eukaryotic Cell, v. 10, n. 9, p. 1173-1182, 2011.

VAZ, A.; TOZZI, A. Bauhinia ser. Cansenia (Leguminosae: Caesalpinioideae) no Brasil. Rodriguesia, v. 54, n. 83, p. 55-143, 2003.

WHIBLEY, N.; GAFFEN, S. L. Beyond Candida albicans: Mechanisms of immunity to nonalbicans Candida species. Cytokine, v. 76, n. 1, p. 42-52, 2015.

WILlINGER, B.; HAASE, G. State-of-the-Art Procedures and in Diagnostic Medical Mycology. Current Fungal Infection Reports, v. 7, p. 260-272, 2013.

YAPAR, N. Epidemiology and risk factors for invasive candidiasis. Journal of Therapeutics and Clinical Risk Management, v. 10, p. 95-105, 2014.

ZAITZ, C. et al. Compêndio de Micologia Médica. 2. Rio de Janeiro: GUANABARA KOOGAN, 2010. 432p. 
ZHANG, L. et al. Surveillance of antifungal susceptibilities in clinical isolates of Candida species at 36 hospitals in China from 2009 to 2013. International Journal of Infectious Diseases, v. 33, p. 1-4, 2015. 


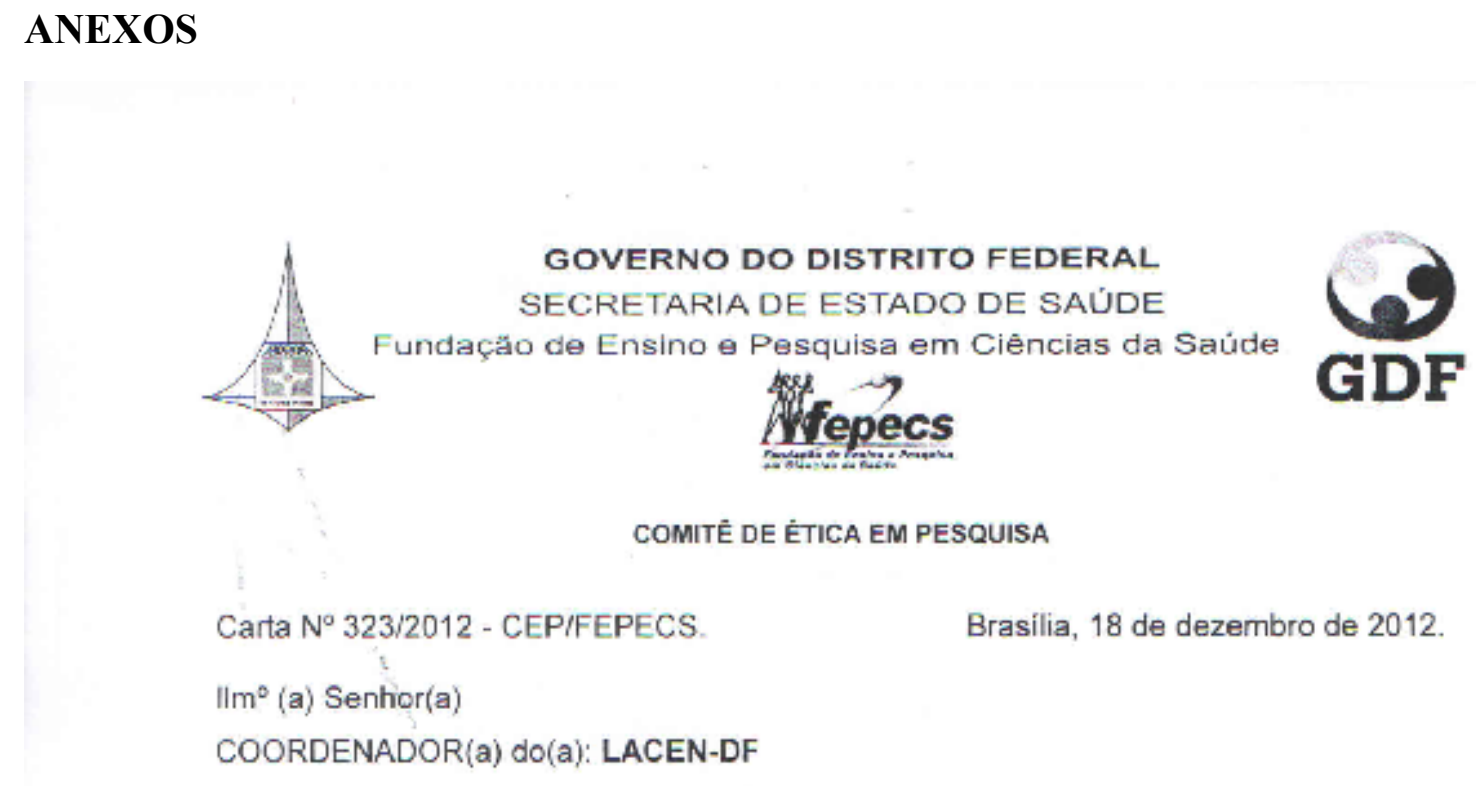

Assunto: aprovação do projeto de pesquisa - 206/2012 - CEP/SES/DF

Senhor(a) Coordenador(a).

Participamos a V. Sa, que o projeto AVALIAÇÃO DO POTENCIAL ANTIFUNGICO DE PLANTAS DO CERRADO FRENTE A CANDIDA ISOLADA DE MICOSES PROFUNDAS encontra-se em conformidade com a Resoluçāo 196/96 Conselho Nacional de Saúde/Ministério da Saúde - CNS/MS e suas complementares.

Data da aprovaçāo: 12/03/2012

Validade do parecer: $12 / 03 / 2015$

Pesquisador responsável e telefone: AMABEL. FERNANDES CORREIA - 33210395

Os dados serão coletados na SES-DF e o pesquisador deverá observar as responsabilidades que the säo atribuidas na Resoluçäo 196/96 CNSMS, incisos IX.1 e IX.2, em relação ao desenvolvimento do projeto, bem como a responsabilidade de acompanhar a coleta de dados junto aos demais pesquisadores do projeto.

Ressaltamos que a conduta do pesquisador, assim como o seu acesso à Unidade de Saúde deve seguir as normas e os procedimentos preconizados pela Secretaria de Estado de Saúde do Distrito Federal. O pesquisador deve se apresentar ao Diretor da Unidade de Saúde para os procedimentos administrativos necessários.

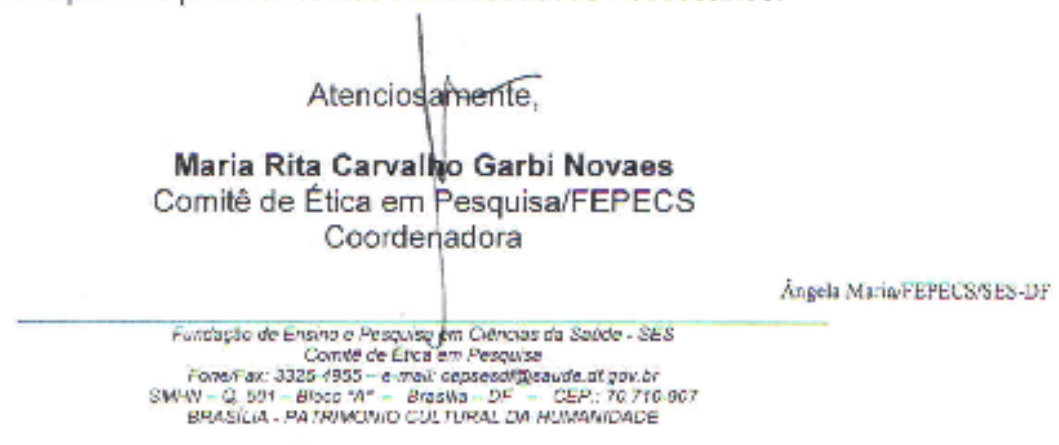

